Algoritmo de escalonamento para aplicações em uma grade computacional extensível aos receptores de sinais digitais de televisão

\author{
Bruno Guazzelli Batista
}



Data de Depósito:

Assinatura:

\title{
Algoritmo de escalonamento para aplicações em uma grade computacional extensível aos receptores de sinais digitais de televisão
}

\author{
Bruno Guazzelli Batista
}

Orientadora: Profa. Dra. Regina Helena Carlucci Santana

Dissertação apresentada ao Instituto de Ciências Matemáticas e de Computação - ICMC-USP, como parte dos requisitos para obtenção do título de Mestre em Ciências - Ciências de Computação e Matemática Computacional. VERSÃO REVISADA

USP - São Carlos

Agosto de 2011 
Ficha catalográfica elaborada pela Biblioteca Prof. Achille Bassi e Seção Técnica de Informática, ICMC/USP, com os dados fornecidos pelo(a) autor(a)

Batista, Bruno Guazzelli
Algoritmo de Escalonamento para Aplicações em uma
Grade Computacional Extensivel aos Receptores de
Sinais Digitais de Televisão / Bruno Guazelli
Batista; orientadora Regina Helena Carlucci Santana -
- São Carlos, 2011.
118 p.
Dissertação (Mestrado - Programa de Pós-Graduação en
Ciências de Computação e Matemática Computacional) --
Instituto de Ciências Matemáticas e de Computação,
Universidade de São Paulo, 2011.
1. Grade Computacional. 2. TV Digital. 3.
Receptores Digitais. 4. Políticas de Escalonamento.
5. Simulação. I. Santana, Regina Helena Carlucci,
orient. II. Título.




\section{Agradecimentos}

Gradeço primeiramente a Deus pelas oportunidades que me são dadas, pela minha família
e pelos obstáculos que aparecem no meu caminho, pois são eles que me fazem crescer e
me motivam a procurar novos desafios.

A minha família, especialmente a minha mãe Marita por sempre estar ao meu lado em todos os momentos, sejam eles de alegria ou de tristeza, pela estrutura e apoio dado ao logo de minha vida e por sempre acreditar em mim.

Aos meus irmãos Camila e Ângelo que junto a minha mãe são a motivação de meu viver.

A todos os integrantes do LASDPC pelos momentos de descontração e pelas contribuições ao logo dessa jornada.

Agradeço a todo o corpo docente que integra o LASDPC, em especial a minha orientadora Regina Helena Carlucci Santana pela orientação, dedicação e pela oportunidade de trabalharmos juntos na realização deste trabalho.

Aos meus amigos e amigas da Rep. Tibilisku Paulo Sérgio, Gabriel Massote, Bruno Tardiole, Daniel Pigatto, João Paulo, Lívia, Lidiane e Nathália pelos ótimos momentos que passamos juntos e pelos fortes laços de amizades que construímos ao longo destes anos.

Enfim, agradeço a todos que direta ou indiretamente contribuíram para que eu chegasse aonde estou. 

Grid Anywhere é um middleware de grade computacional ponto-aponto (P2P), capaz de agrupar em uma organização virtual ou federação qualquer equipamento dotado de recursos computacionais, inclusive receptores digitais. O objetivo deste projeto de mestrado apresentado nesta monografia é desenvolver e avaliar algoritmos de escalonamento que possibilitem uma distribuição adequada de processos nos elementos da grade computacional proposta pelo Grid Anywhere. Foram realizados experimentos utilizando o simulador GridSim, simulando um ambiente definido por esse middleware. Por meio dessa junção entre Grades Computacionais e TV Digital, pretende-se promover a inclusão digital permitindo que recursos computacionais sejam compartilhados de maneira a possibilitar que usuários com receptores limitados executem aplicações que demandem mais recursos que aqueles ofertados pelo hardware. 

Rid Anywhere is a middleware for grid computing peer-to-peer ( $\mathrm{P} 2 \mathrm{P})$, capable of bringing together into a virtual organization or federation any equipment having computing resources, including digital receivers. The objective of this master's project presented in this monograph is to develop and evaluate scheduling algorithms that allow an adequate distribution of applications in computational grid elements proposed by the Grid Anywhere. Experiments were carried out using the GridSim simulator, simulating an environment defined by the middleware. Through this joint between Grid Computing and Digital TV, it is possible to promote digital inclusion by allowing computing resources to be shared, so as to enable users with limited receivers to run applications that require more resources than those offered by the hardware. 

$\begin{array}{lll}\text { Abstract } & \mathbf{v}\end{array}$

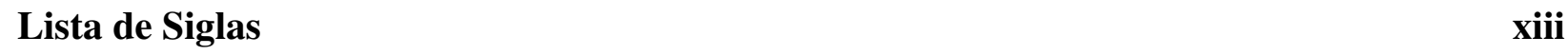

1 Introdução $\quad 1$

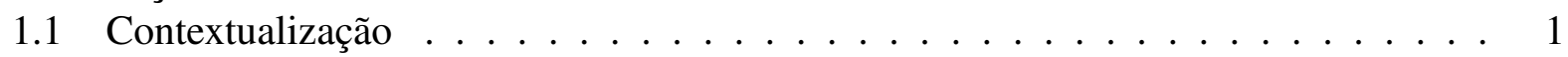

1.2 Motivação e Objetivos . . . . . . . . . . . . . . . . . . . . . . . 2

1.3 Descrição dos Capítulos . . . . . . . . . . . . . . . . 4

2 TV Digital $\quad 5$

2.1 Considerações Iniciais $\ldots \ldots \ldots \ldots \ldots \ldots$

2.2 Mudanças em Relação à Televisão Analógica . . . . . . . . . . . . . . . . . . 6

2.3 Receptores Digitais . . . . . . . . . . . . . . . . . . . . 8

2.3.1 Arquitetura do Receptor Digital . . . . . . . . . . . . . . . . . . 9

2.3.2 Tipos de Receptores . . . . . . . . . . . . . . . . . . 11

2.4 Middleware Ginga . . . . . . . . . . . . . . . . . . . . . . . . . 14

2.5 Aplicações e Interatividade . . . . . . . . . . . . . . . . . . . . . . . . 14

2.6 Canal de Retorno . . . . . . . . . . . . . . . . . . . . . . 16

2.7 Carrossel de Dados . . . . . . . . . . . . . . . . . . . . . . . . . . . . . . . . . . . . . . . . . . . . . . .

2.8 Considerações Finais . . . . . . . . . . . . . . . . . . . . . 19

3 Grades Computacionais $\quad 21$

3.1 Considerações Iniciais . . . . . . . . . . . . . . . . . . . . . 21

3.2 Arquitetura de Grades . . . . . . . . . . . . . . . . . . . . . . . 22

3.3 Especificações OGSA, OGSI e WSRF . . . . . . . . . . . . . . . . . . 25

3.4 Escalonamento em Grades Computacionais . . . . . . . . . . . . . . . . . . . . . . . . . . . 25

3.5 Políticas de Escalonamento para Grades . . . . . . . . . . . . . . . . . . . . . . . . . . . . . . . . . . . .

3.6 Simuladores de Grades Computacionais . . . . . . . . . . . . . . . . . 30

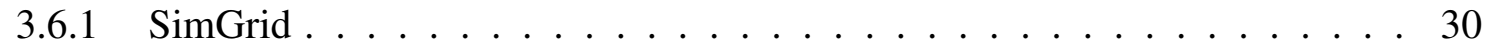

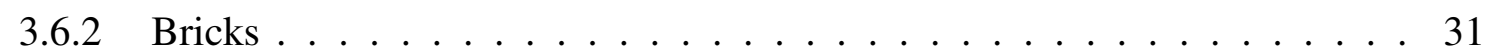

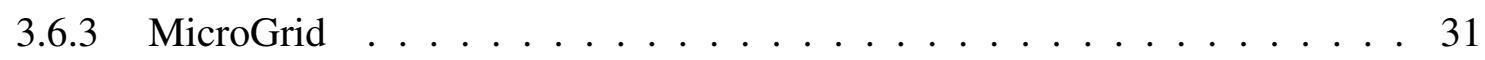

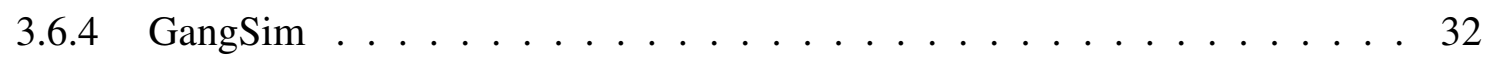

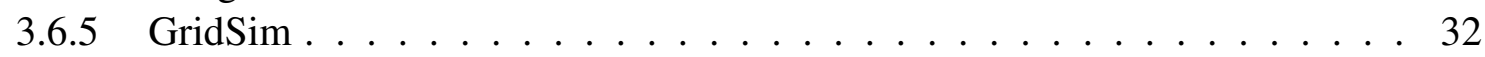


3.7 Projetos que envolvem Grades Computacionais . . . . . . . . . . . . . . . . 35

3.7 .1 Projeto WLCG . . . . . . . . . . . . . . . . 36

3.7 .2 Projeto GPUGRID.net . . . . . . . . . . . . . . . . 38

3.8 Considerações Finais . . . . . . . . . . . . . . . . . 41

4 Grid Anywhere $\quad 43$

4.1 Considerações Iniciais . . . . . . . . . . . . . . . . . . . . . 43

4.2 Arquitetura do Middleware Grid Anywhere . . . . . . . . . . . . . . . . 45

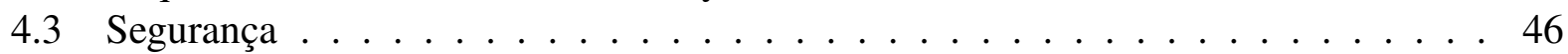

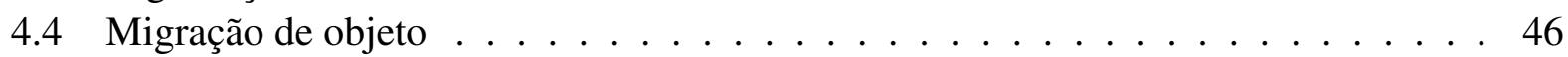

4.5 Considerações Finais . . . . . . . . . . . . . . . . . . . 47

5 Desenvolvimento do Projeto 449

5.1 Considerações Iniciais ． . . . . . . . . . . . . . . . . . . . . . . . . . 49

5.2 Metodologia de Trabalho . . . . . . . . . . . . . . . . . 51

5.3 Modelagem dos Experimentos . . . . . . . . . . . . . . . 53

5.3.1 Classificação dos Receptores Digitais . . . . . . . . . . . . . . . . . . 53

5.3 .2 Classificação das Aplicações Interativas . . . . . . . . . . . . . . . . . . . . 56

5.3 .3 Políticas de Escalonamento . . . . . . . . . . . . . . . . 58

5.4 Projeto dos Experimentos de Análise de Sobrecarga . . . . . . . . . . . . . . 60

6 Avaliação de Algoritmos de Escalonamento $\quad 67$

6.1 Considerações Iniciais . . . . . . . . . . . . . . . . . . . . . 67

6.2 Projeto dos Experimentos . . . . . . . . . . . . . . . . . . 67

6.3 Tempo Médio de Resposta . . . . . . . . . . . . . . . . . . . . . . . 69

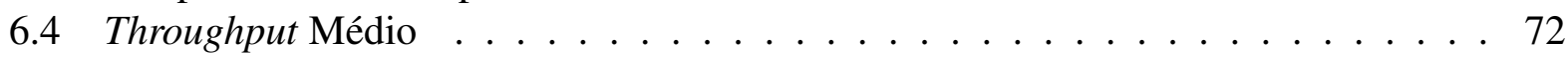

6.5 Influência dos Fatores . . . . . . . . . . . . . . . . . . . . 74

6.5.1 WorkQueue vs Baseada na Capacidade . . . . . . . . . . . . . . . 74

6.5.2 WorkQueue vs Melhor Arranjo . . . . . . . . . . . . . . . . . 76

6.5.3 Baseada na Capacidade vs Melhor Arranjo . . . . . . . . . . . . . . 78

6.6 Conclusões Parciais . . . . . . . . . . . . . . . . . . . . 80

6.7 Considerações Finais . . . . . . . . . . . . . . . . . . . . 85

7 Conclusões $\quad 87$

7.1 Considerações Iniciais . . . . . . . . . . . . . . . . . . 87

7.2 Resultados Obtidos . . . . . . . . . . . . . . . . . . 88

7.3 Conclusão Final . . . . . . . . . . . . . . . . . . . . . . . . . . . . . . . . . . . . . . . . . .

7.4 Trabalhos Futuros . . . . . . . . . . . . . . . . . . . . . . 89 


\section{Lista de Figuras}

2.1 Produção e Transmissão, adaptado de (Montez e Becker, 2005). . . . . . . . . . . 8

2.2 Arquitetura do Hardware, adaptado de (O'driscoll, 1999) (Montez e Becker, 2005). 10

2.3 Arquitetura do Software, adaptado de (O’driscoll, 1999) (Montez e Becker, 2005). 11

2.4 Emprego do Canal de Retorno em um Sistema de Televisão Digital Interativa $(\mathrm{DTV}, 2011) \ldots \ldots \ldots \ldots \ldots \ldots \ldots$

3.1 Modelo de Camadas de uma Grade Computacional (Foster et al., 2001) (Teixeira, 2009). . . . . . . . . . . . . . . . . . 23

3.2 Relacionamento entre escalonador, recursos e usuários (Maheswaran et al., 1999). 27

3.3 Arquitetura do GridSim 4.1 (Buyya e Murshed, 2002). . . . . . . . . . . . . . . . 33

3.4 Localização e parte do anel do LHC (LHC, 2008). . . . . . . . . . . . . . . . . 36

3.5 Laboratório do CERN para o projeto WLCG (Cern, 2008). . . . . . . . . . . . . . 37

3.6 Comparação de desempenho entre processadores (Mercury, 2006). . . . . . . . . . 39

4.1 Ambiente Grid Anywhere (Teixeira, 2009) (Teixeira et al., 2010). . . . . . . . . . 44

4.2 Arquitetura do Middleware Grid Anywhere (Teixeira et al., 2010). . . . . . . . . . 45

4.3 Padrão de troca de mensagens no Grid Anywhere (Teixeira et al., 2010). . . . . . . 47

5.1 Distribuição das Aplicações para as Federações. . . . . . . . . . . . . . . . 50

5.2 Tempo Médio de Resposta com 30 usuários e 50 e 100 equipamentos. . . . . . . . 61

5.3 Tempo Médio de Resposta com 60 usuários e 50 e 100 equipamentos. . . . . . . . . 62

5.4 Tempo Médio de Resposta em 50 e 100 Equipamentos Classe 1. . . . . . . . . . . 63

5.5 Tempo Médio de Resposta em 50 e 100 Equipamentos Classe 2. . . . . . . . . . . . 64

5.6 Tempo Médio de Resposta em 50 e 100 Equipamentos Classe 3. . . . . . . . . . . 65

6.1 Tempo Médio de Resposta - 2 Federações. . . . . . . . . . . . . . . . . . . . 70

6.2 Tempo Médio de Resposta - 4 Federações. . . . . . . . . . . . . . . . . . . . 71

6.3 Throughput Médio - 2 Federações. . . . . . . . . . . . . . . . . . 72

6.4 Throughput Médio - 4 Federações. . . . . . . . . . . . . . . . . . . . . 73

6.5 Influência dos Fatores sobre o Tempo Médio de Resposta - Combinação WQ x BC. 74

6.6 Influência dos Fatores sobre o Throughput Médio - Combinação WQ x BC. . . . . 76

6.7 Influência dos Fatores sobre o Tempo Médio de Resposta - Combinação WQ x

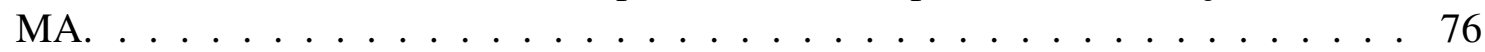

6.8 Influência dos Fatores sobre o Throughput Médio - Combinação WQ x MA. . . . 78

6.9 Influência dos Fatores sobre o Tempo Médio de Resposta - Combinação BC x MA. 78

6.10 Influência dos Fatores sobre o Throughput Médio - Combinação BC x MA. . . . . 80 
6.11 Tempo Médio de Resposta - Política WQ . . . . . . . . . . . . . . . . . . . . 80

6.12 Tempo Médio de Resposta - Política BC . . . . . . . . . . . . . . . . . . 81

6.13 Tempo Médio de Resposta - Política MA. . . . . . . . . . . . . . . . . . . . . . . 82

6.14 Throughput Médio - Política WQ . . . . . . . . . . . . . . . . 83

6.15 Throughput Médio - Política BC. . . . . . . . . . . . . . . . . 84

6.16 Throughput Médio - Política MA. . . . . . . . . . . . . . . 85 


\section{Lista de Tabelas}

5.1 Especificações dos Equipamentos Analisados.

5.2 Classificação dos Receptores Digitais que Utilizam Processadores de Propósito Geral. . . . . . . . . . . . . . . . . . . 55

5.3 Classificação dos Receptores Digitais que Utilizam Processadores Específicos. . 55

5.4 Classificação dos Recursos. . . . . . . . . . . . . . . . . . . . 56

5.5 Porcentagem de Uso do Processador. . . . . . . . . . . . . . . . . . . 57

5.6 Uso do Processador em MIPS. . . . . . . . . . . . . . . . . . . . . 57

5.7 Composição das Cargas Simuladas. . . . . . . . . . . . . . . . . 58

5.8 Atribuição do Número de Aplicações. . . . . . . . . . . . . . . . . . . . . . 59

6.1 Configuração do Modelo Fatorial. . . . . . . . . . . . . . . . . . . . . . . . . 69

6.2 Tabelas com os Valores do Tempo Médio de Resposta em 2 Federações. . . . . . . 70

6.3 Tabelas com os Valores do Tempo Médio de Resposta em 4 Federações. . . . . . . . 71

6.4 Tabelas com os Valores do Throughput Médio em 2 Federações. . . . . . . . . . . . 72

6.5 Tabelas com os Valores do Throughput Médio em 4 Federações. . . . . . . . . . . . 73

6.6 Influência dos Fatores - WQ x BC. . . . . . . . . . . . . . . . . . 75

6.7 Influência dos Fatores - WQ x MA. . . . . . . . . . . . . . . . . 77

6.8 Influência dos Fatores - BC x MA. . . . . . . . . . . . . . . . . 79 



\author{
ADSL - Assymetrical Digital Subscriber Line \\ ALICE - A Longe Ion Collider Experiment \\ API - Applications Programming Interface \\ ATLAS - A Toroidal LHC ApparatuS \\ ATSC - Advanced Televison Systems Commitee \\ BC - Baseada na Capacidade \\ BOINC - Berkeley Open Infrastructure for Network Computing \\ Cell BE - Cell Broadband Engine \\ CERN - Conseil Européen pour la Recherche Nucléaire - \\ European Organization for Nuclear Research \\ CMP - Capacidade Média de Processamento \\ CMS - Compact Muon Solenoid \\ CPqD - Centro de Pesquisa e Desenvolvimento em Telecomunicações \\ CUDA - Complete Unified Device Architecture \\ DLNA - Digital Living Network Alliance \\ DSM - Domain Security Manager \\ DSM-CC - Digital Storage Media Command and Control Protocol \\ DVB - Digital Video Broadcasting \\ EAD - Aplicações de Ensino a Distância \\ EGEE - Enabling Grids for E-sciencE \\ EPG - Eletronic Program Guide \\ FGTS - Fundo de Garantia do Tempo de Serviço
}




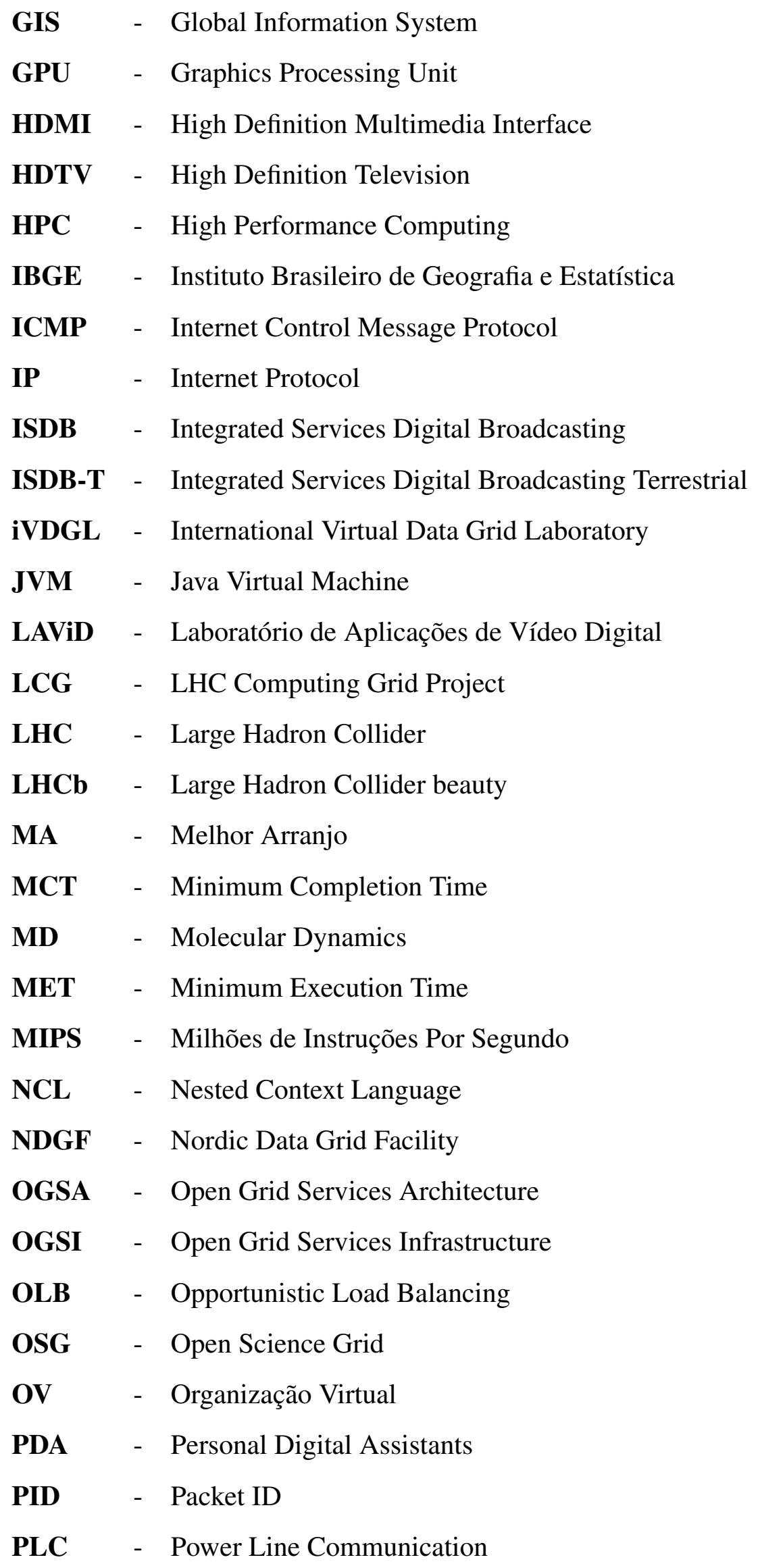




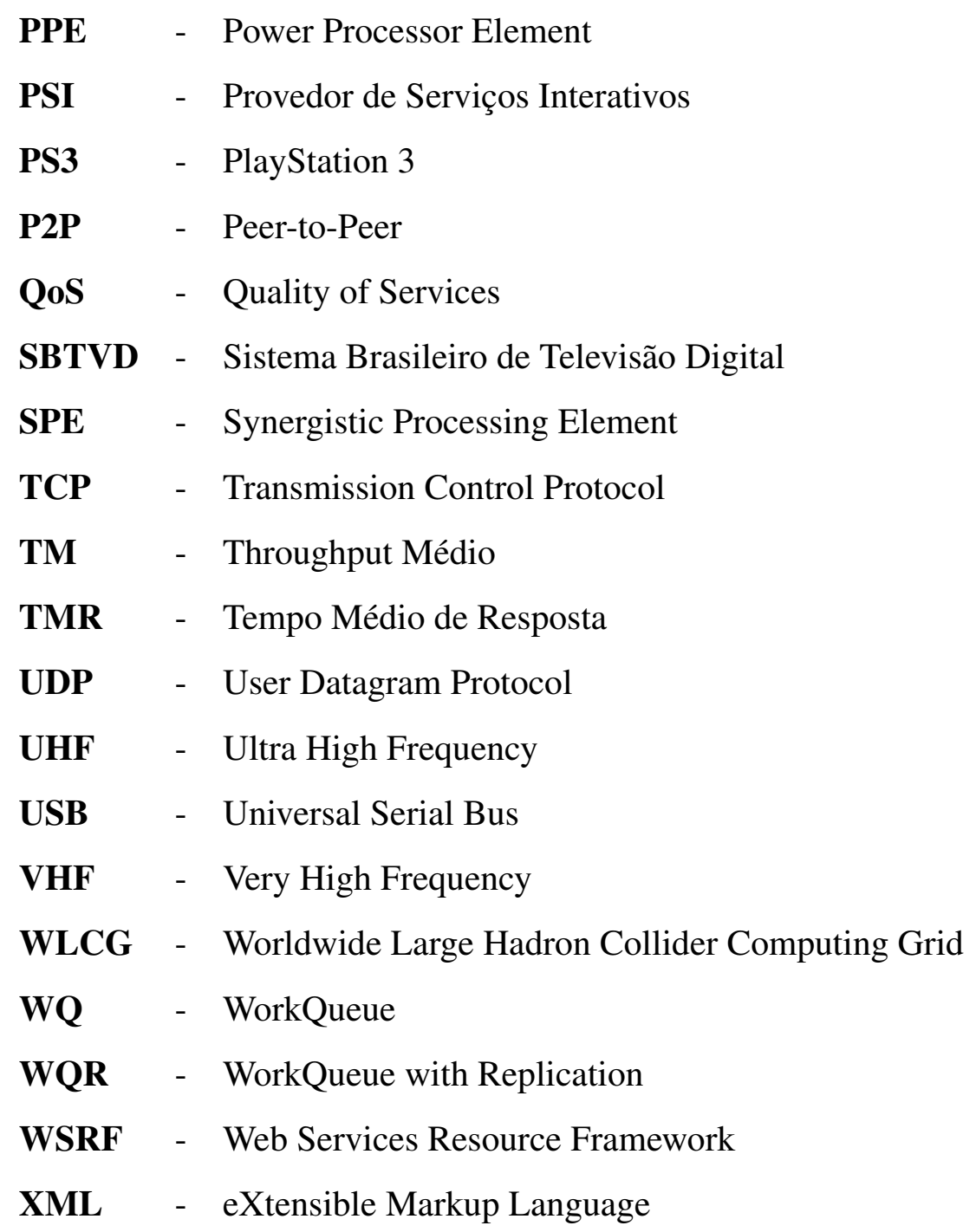




\subsection{Contextualização}

Desde o início da era da computação um dos maiores interesses na área de pesquisa tem sido o aumento do poder de processamento dos computadores. À medida que o tempo vai passando novas tecnologias de software exigem máquinas mais potentes e uma potência computacional cada vez maior. Essa tendência da tecnologia tem exigido dos distribuidores de processadores uma rápida evolução tecnológica. No entanto, muitas vezes a tecnologia empregada em um processador não consegue sozinha, atender os casos onde a demanda de recursos de processamento é grande, surgindo assim, as máquinas paralelas dotadas de um número maior de processadores. Para algumas aplicações o número de processadores necessários torna a solução inadequada, devido à inviabilidade econômica do projeto na construção ou aquisição de uma máquina paralela do porte necessário.

A computação em grade tornou-se uma solução viável para os casos que apresentam uma grande demanda de processamento (Foster et al., 2002). Como os computadores envolvidos no sistema em grade são de propriedade de usuários voluntários (computação filantrópica), que disponibilizam seus equipamentos para fazerem parte do trabalho, o custo da computação em grade torna-se inferior ao das máquinas paralelas. Esse paradigma permite que participantes geograficamente distribuídos e sob administrações independentes compartilhem entre si recursos computacionais ociosos que podem variar de processadores e discos rígidos até licenças de software (Foster et al., 2001) (Teixeira, 2009). Exemplos de recursos que podem ser utilizados são celulares, PDAs (Personal Digital Assistants), receptores de sinais digitais de televisão, entre outros equipamentos. 
Atualmente, está em implantação no Brasil o Sistema de Televisão Digital. Para que os telespectadores possam fazer uso de todas as vantagens providas por esse sistema é necessária a existência de um receptor de sinais digitais dotado de recursos computacionais convencionais como, por exemplo, unidade de processamento, disco rígido e memória.

Os receptores digitais são dispositivos computacionais e podem apresentar diferentes configurações de hardware e software (inclusive sistema operacional), originando uma heterogeneidade considerável. Muitos desses recursos podem permanecer ociosos, possibilitando a criação de uma grade computacional que permita que eles sejam compartilhados para que, de forma conjunta, possam ser utilizados para prover um ambiente de alto desempenho.

Para que uma mesma aplicação enviada via broadcasting por uma emissora possa ser executada em todos os receptores existentes, é necessário um middleware (uma camada de software entre as aplicações e o sistema operacional). O middleware oferece um serviço padronizado para as aplicações, escondendo peculiaridades das camadas inferiores como, por exemplo, a tecnologia utilizada para a compressão e modulação do sinal digital. Ele permite que haja portabilidade das aplicações, de forma que elas possam ser transmitidas para outros receptores que adotam diferentes middlewares (Montez e Becker, 2005).

Uma forte sinalização do que deverá se tornar o receptor digital no Brasil é o middleware Ginga (Ginga, 2011), que é subdividido em dois subsistemas principais interligados chamados Ginga-J e Ginga-NCL. O Ginga-NCL (NCL - Nested Context Language) é um ambiente para apresentação multimídia de aplicações interativas, enquanto que o Ginga-J provê uma infra-estrutura de execução de aplicações Java (Ginga, 2011). Esse middleware permite que aplicações declarativas, escritas em NCL e Lua (LUA, 2011), e procedurais, escritas em Java, sejam executadas no receptor digital. Essa implementação abre um horizonte de grandes possibilidades para a execução de aplicações no equipamento.

\subsection{Motivação e Objetivos}

Com a implantação do Sistema de Televisão Digital, o Brasil pode possuir, em um período de tempo inferior a dez anos, um número aproximado de 80 milhões de receptores digitais (Batista et al., 2007).

Pelo fato de manipular dados além de áudio e vídeo digitais, parte da arquitetura de um receptor digital é muito similar a de um computador pessoal. Potencialmente, uma grande quantidade de recursos computacionais pode se encontrar ociosa nesses equipamentos e, considerando a existência de um canal de comunicação que permita que os receptores possam se comunicar com a Internet, a formação de uma grade computacional utilizando esses equipamentos torna-se interessante.

Essa grade computacional pode ser utilizada para prover uma grande potência computacional para auxiliar na solução de problemas que exigem um nível elevado de processamento, tendo em vista o uso conjunto dos recursos dos receptores. No entanto, os telespectadores também podem 
ser beneficiados, pois quem possui um receptor digital que tenha recursos limitados, pode utilizar outros equipamentos remotos para aumentar a sua capacidade de execução de aplicações. Isso pode contribuir para a inclusão digital, que é um dos objetivos do governo federal, segundo o Decreto Presidencial 4901 que estipulou o Sistema Brasileiro de Televisão Digital (SBTVD) (Planalto, 2003).

Pensando nisso, Teixeira, em (Teixeira, 2009) (Teixeira et al., 2010), propôs um middleware denominado Grid Anywhere para grades computacionais que considera duas tecnologias: Grades Computacionais e Televisão Digital. Esse middleware permite a criação de uma grade computacional ponto-a-ponto (P2P) capaz de agrupar em uma única Organização Virtual (OV) ou Federação, computadores convencionais e diversos tipos de equipamentos, como por exemplo, receptores digitais. Essa grade computacional pode ser utilizada para prover uma grande potência computacional para auxiliar na solução de problemas que exigem um nível elevado de processamento, tendo em vista o uso conjunto dos recursos dos receptores.

Existem outros projetos que utilizam grades computacionais compostas por diferentes equipamentos computacionais. Um exemplo é a grade utilizada no projeto GPUGRID.net. Também conhecido por PS3GRID.net, é um projeto de computação distribuída com o objetivo de auxiliar pesquisas na área da biologia molecular. Este projeto utiliza grades computacionais formadas por computadores com placas de vídeo que dispõem de unidade de processamento gráfico (GPU Graphics Processing Unit) e por consoles de PlayStation 3 (PS3) (GPUGRID.net, 2011).

Realizando-se uma análise da tendência que grande parte das tecnologias digitais segue, observase que o telefone celular em sua concepção tinha a função de permitir a comunicação via voz entre duas pessoas. Com a evolução desses aparelhos, percebe-se que hoje a aplicação original a ele atribuída é apenas mais uma de suas inúmeras aplicações, o que o tornou um dos aparelhos mais vendidos no país.

O projeto de mestrado apresentado nesta monografia considera que algo similar venha a acontecer aos receptores digitais. Já existem no mercado diversos tipos de equipamentos receptores com as mais variadas configurações e funcionalidades. No entanto, para que a inclusão digital (uma das metas a serem alcançadas com criação do Decreto Presidencial 4901) se concretize, é necessário que a população de baixa renda tenha acesso a esses equipamentos a um preço acessível. Porém, os equipamentos mais baratos possuem recursos limitados.

No Grid Anywhere os telespectadores com equipamentos com menor potência computacional também podem ser beneficiados, pois é possível que um receptor que tenha recursos limitados faça uso de equipamentos remotos para aumentar a sua capacidade de execução de aplicações.

No entanto, a possibilidade de existir, potencialmente, um grande número de participantes na grade computacional proposta pelo Grid Anywhere torna necessário que o mecanismo de escalonamento seja bastante robusto e eficaz. Em uma máquina com apenas um processador, o tempo de processamento deve ser dividido entre os processos. Em um ambiente global, como é o caso das grades computacionais, deve ser definido o elemento de processamento onde o processo será executado, isto é, deve-se considerar um algoritmo para escalonamento dos processos. 
O objetivo deste projeto de mestrado é propor e avaliar algoritmos de escalonamento que possibilitem uma distribuição adequada de processos nos elementos da grade computacional proposta pelo Grid Anywhere. Isto é, pretende-se avaliar algoritmos de escalonamento que consideram um cenário de sistema distribuído que utiliza os receptores digitais dos equipamentos domésticos de televisão nos papéis de provedores e consumidores de recursos computacionais. Para viabilizar a avaliação proposta como objetivo é necessário realizar uma caracterização dos receptores digitais disponíveis no mercado e de algumas aplicações interativas. Baseando-se nessa caracterização, pode-se modelar e simular ambientes de grade computacional com as características do Grid Anywhere. Nas simulações pode-se verificar a sobrecarga que uma determinada aplicação impõe sobre um determinado tipo de receptor digital e avaliar as três políticas de escalonamento consideradas nesta dissertação de mestrado.

\subsection{Descrição dos Capítulos}

Este trabalho está dividido nos seguintes capítulos:

- No Capítulo Dois é feita uma contextualização sobre o Sistema Brasileiro de Televisão Digital. São apresentadas as principais mudanças em relação ao modelo analógico, bem como as características de cada elemento que compõe esse novo sistema.

- No Capítulo Três é descrita toda a fundamentação teórica sobre grades computacionais, passando por arquitetura, algoritmos de escalonamento, simuladores e projetos existentes como o projeto GPUGRID.net, citado anteriormente.

- O Capítulo Quatro apresenta as características do middleware Grid Anywhere.

- As etapas de desenvolvimento do projeto, incluindo sua especificação e metodologia além dos estudos realizados para a classificação dos receptores digitais e caracterização das aplicações interativas disponíveis são descritas no Capítulo Cinco.

- O Capítulo Seis mostra a avaliação de desempenho do ambiente simulado e os resultados obtidos com a realização deste trabalho.

- Por fim, o Capítulo Sete resume os principais resultados, as contribuições do projeto e os trabalhos futuros sugeridos. 


\section{CAPÍTULO}

\section{2}

TV Digital

\subsection{Considerações Iniciais}

Em 1996, iniciou-se no Brasil, a TV com formato digital através da TV por assinatura via satélite como DirecTV e SKY. Apesar da imagem ser transmitida em sinal digital, esses sistemas não permitiam a alta definição e a interatividade era bastante limitada. Em 1998, iniciou-se as discussões para a implantação da TV Digital aberta no país. Três padrões mundiais existiam: o ATSC (Advanced Television Systems Commitee) - padrão americano (ATSC, 2011), o DVB (Digital Video Broadcasting) - padrão europeu (DVB, 2011) e o ISDB (Integrated Services Digital Broadcasting) - padrão japonês (Fernandes et al., 2004) (Montez e Becker, 2005). O ATSC foi projetado para operar com conteúdo audiovisual em alta definição (HDTV); o DVB trabalha com multiprogramação uma vez que observa-se uma grande diversidade cultural na Europa; por fim o ISDB é considerado o mais flexível por responder melhor as necessidades de mobilidade e portabilidade.

Após diversos testes comparativos ratificados pela fundação $\mathrm{CPqD}^{1}$ (Centro de Pesquisa e Desenvolvimento em Telecomunicações) (CPqD, 2011), foi anunciado em 29 de junho de 2006, o ISDB como padrão adotado pelo Brasil na transmissão de TV Digital Terrestre. Essa preferência é justificada pela capacidade do sistema atender a equipamentos portáteis, permitindo, por exemplo, que o público assista TV em celulares, mini-televisores, automóveis e em outros dispositivos móveis. Além disso, proporciona alta definição e interatividade para terminais móveis e fixos (DTV, 2011).

\footnotetext{
${ }^{1} \mathrm{O} C P q D$ é uma instituição independente, focada na inovação com base nas tecnologias da informação e comunicação, tendo como objetivo contribuir para a competitividade do país e para a inclusão digital da sociedade.
} 
A partir daí, os pesquisadores brasileiros acrescentaram uma série de atualizações no ISDB-T (Integrated Services Digital Broadcasting Terrestrial), como avanços na codificação de áudio e vídeo, nos padrões de middleware e em vários outros sistemas, mantendo as características essenciais de robustez e eficiência que fazem do sistema japonês a melhor opção para o uso racional do espectro de transmissão. Assim então surgiu o ISDB-Tb, um padrão de transmissão de TV Digital Terrestre desenvolvido no Brasil, tendo como base o sistema japonês ISDB-T pré-existente, acrescentando tecnologias desenvolvidas nas universidades brasileiras. Com isso, após seis meses de transmissões experimentais, foi realizada a primeira transmissão de sinais digitais na cidade de São Paulo no dia 2 de dezembro de 2007.

De acordo com o cronograma estipulado para implantação do Sistema Brasileiro de Televisão Digital (SBTVD), até 2013 todos os rádio-difusores transmitirão no formato ISDB-T e o desligamento dos sinais de TV analógica está agendado para iniciar em 2016.

Segundo a página oficial da TV Digital Brasileira (DTV, 2011), desde a sua implantação, a transmissão terrestre do sinal digital se expandiu por 23 estados mais o Distrito Federal, totalizando 480 municípios espalhados por todo o país. A cobertura cresce a ritmo acelerado atingindo o equivalente a 87,7 milhões de pessoas, ou $45,98 \%$ da população brasileira. A expectativa é que a cobertura do SBTVD seja igual ou superior à cobertura analógica atual antes mesmo de 2016. Além disso, diversos países já aderiram ao ISDB-Tb, são eles: Peru, Chile, Argentina, Venezuela, Equador, Costa Rica, Paraguai, Bolívia, Nicarágua, Filipinas, Japão e mais recentemente o Uruguai.

\subsection{Mudanças em Relação à Televisão Analógica}

Segundo o Decreto Presidencial $n^{\circ}$ 4901, o SBTVD, além de promover recursos de entretenimento e cultura, a televisão digital deve promover diversos outros benefícios como, por exemplo, a democratização da informação através da inclusão digital e aprendizagem à distância (Planalto, 2003).

Além disso, esse sistema deve oferecer outros benefícios aos telespectadores como:

- Melhor qualidade de áudio e vídeo: a adoção de formato digital na geração, transmissão, recepção e reprodução de programas de TV torna possível a utilização de mecanismos computacionais que auxiliam de forma significativa a obtenção de resultados melhores que aqueles oferecidos no modelo analógico. Um exemplo disso é a eliminação dos fantasmas, interferências e ruídos presentes no modelo analógico.

- Maior programação: a utilização da compressão de dados permite que o conteúdo transmitido possa ser reduzido. Nesse caso, um mesmo canal físico de transmissão terrestre (UHF/VHF - Ultra High Frequency/Very High Frequency), que no modelo analógico comporta apenas uma programação, é capaz de trafegar quatro no modelo digital, com qualidade 
superior de áudio e vídeo. Além disso, o aumento da quantidade de informações suportadas pelo canal físico (que no Brasil é de $6 \mathrm{MHz}$ na transmissão terrestre) permite ainda a transmissão de dados digitais de qualquer natureza como, por exemplo, aplicações interativas (Fernandes et al., 2004).

- Mobilidade: a mobilidade é uma questão interessante que o sistema digital oferece. A tecnologia que começa a ser implantada no Brasil permite que aparelhos portáteis como celulares, notebooks, automóveis, possam ser utilizados na recepção e reprodução dos programas de televisão, proporcionando assim maior flexibilidade ao telespectador (Zuffo, 2006).

- Interatividade: no modelo analógico, o telespectador tem papel totalmente passivo, visto que a única possibilidade que ele tem é a de assistir o conteúdo transmitido pela emissora. No entanto, a presença de interatividade modifica totalmente a forma com que a população faz uso do aparelho televisor. Através do controle remoto ou por meio de outros periféricos, o usuário pode, por exemplo, enviar opiniões sobre o programa assistido, participar de enquetes, votações e solicitar aplicativos à emissora (lembrando que para isso é necessário um meio para comunicação entre a emissora e o telespectador conhecido como Canal de Retorno, a ser descrito na Seção 2.6) (CPqD, 2006).

Muitas mudanças são necessárias na implantação do Sistema de TV Digital Terrestre. Torna-se necessário o desenvolvimento de novas tecnologias para adaptação do sistema analógico para o digital. Essas mudanças estão presentes desde a produção do conteúdo, transmissão, recepção e canal de retorno. A Figura 2.1 mostra o procedimento realizado na produção e transmissão de conteúdo digital.

A Central de Produções (estúdios) de uma emissora é responsável pela geração do áudio e vídeo que será transmitido para o telespectador. Essa geração pode ser realizada ao vivo ou passar pelo setor de edição onde são realizadas algumas alterações no conteúdo. Em seguida, áudio e vídeo são enviados para os seus respectivos codificadores que geram seus próprios fluxos de dados.

Para que haja interatividade, dados devem ser integrados junto ao áudio e ao vídeo formando um único fluxo para que esses dados sejam transmitidos e recebidos pelo aparelho receptor. $\mathrm{O}$ Gerador de Carrossel é capaz de transformar um conjunto de dados em um fluxo elementar, empregando um esquema de transmissão cíclica de dados (Fernandes et al., 2004). O funcionamento do Carrossel de Dados será descrito na Seção 2.7 desta dissertação. Em seguida, o multiplexador funde um ou mais fluxos de dados aos fluxos de áudio e vídeo para que possam ser modulados. O processo de Modulação descreve a maneira como a informação é "empacotada" para ser difundida. Em outras palavras é o processo em que certas características de uma onda eletromagnética (também chamada de portadora) variam de acordo com uma mensagem que se deseja transmitir (Montez e Becker, 2005). Após ser modulada, a informação digital é difundida. Na TV Digital Terrestre isso é feito por rádio-difusão. 


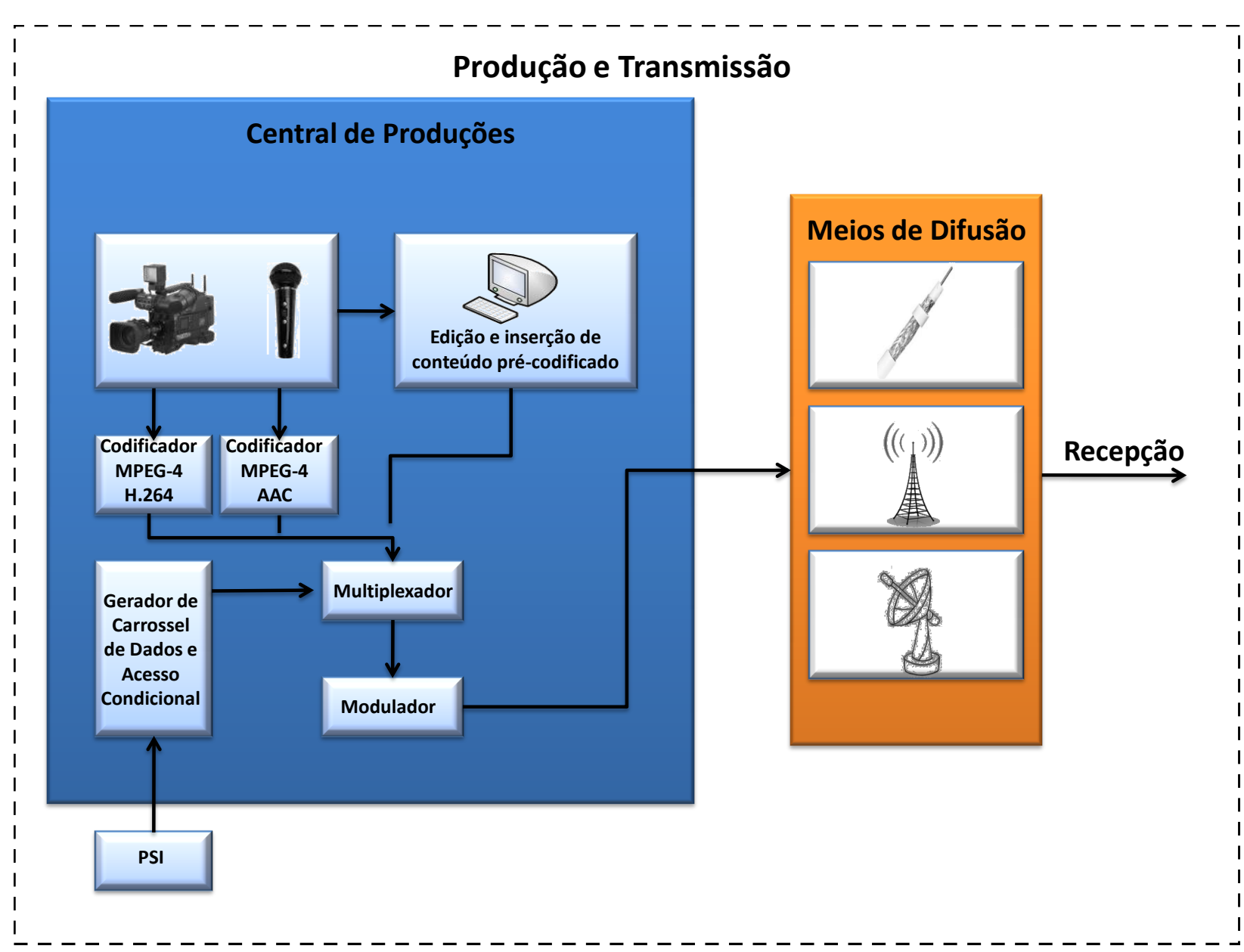

Figura 2.1: Produção e Transmissão, adaptado de (Montez e Becker, 2005).

Os dados enviados para os telespectadores são gerados pelo Provedor de Serviços Interativos (PSI), que pode ser um módulo da própria emissora ou ser uma empresa contratada por ela (Fernandes et al., 2004) (Montez e Becker, 2005) (Neves, 2010). Ele pode exercer várias funções, como por exemplo, gerar todas as interatividades que uma emissora precisa com seus respectivos filtros, além de armazenar, tratar e processar os dados enviados pelo telespectador após responder uma interatividade. No entanto, para que o telespectador receba esses dados é necessário um Receptor Digital.

\subsection{Receptores Digitais}

Para que um aparelho televisor seja capaz de realizar todos os procedimentos para apresentar uma programação (processamento do fluxo de transporte, decodificação, apresentação de áudio e vídeo, execução de programas, comunicação com emissoras de televisão, entre outros) é preciso que o aparelho televisor tenha todos os recursos necessários incorporados. Durante o período de transição muitos aparelhos analógicos continuarão em uso. Sendo assim, para que esses aparelhos possam ser utilizados no Sistema de Televisão Digital, é necessária a existência de um terminal de 
acesso capaz de realizar as funções citadas. Esse terminal de acesso é denominado Receptor de Sinais Digitais (Teixeira, 2009). Ele possui as seguintes funcionalidades básicas (O'driscoll, 1999) (Piccolo, 2005) (ABNT, 2007):

- Demultiplexar o sinal digital recebido;

- Decodificar informações de áudio e vídeo;

- Processar os dados recebidos e, se for o caso, sincronizá-los com a programação.

- Enviar dados via canal de retorno;

- Construir a imagem a ser exibida no aparelho de TV e converte-la para o sinal analógico.

Uma vez que o Receptor Digital pode receber códigos executáveis, ele possui um sistema operacional e um ambiente de execução dos programas. Esses receptores podem apresentar diferentes configurações de hardware e software, originando uma considerável heterogeneidade.

\subsubsection{Arquitetura do Receptor Digital}

Pelo fato de manipular dados além de áudio e vídeo digitais, parte da arquitetura de um receptor é muito similar a de um computador pessoal. As arquiteturas de hardware e software são descritas a seguir.

\section{Hardware}

A Figura 2.2 apresenta os módulos principais da arquitetura de um receptor, que são usualmente implementados em hardware. Nesta Seção é detalhado cada um desses módulos (O'driscoll, 1999) (Montez e Becker, 2005) (ABNT, 2007):

- Sintonizador: seleciona um canal VHF ou UHF (6 MHz) onde existe informação de áudio e vídeo e converte o sinal de radiofreqüência para sinal de banda base codificado, que pode ser mais facilmente manipulado pelos componentes adjacentes.

- Demodulador: sua função é amostrar o sinal sintonizado e convertê-lo em feixes de bits denominados Transport Streams, que contém áudio, vídeo e dados codificados. Uma vez que o stream é recuperado, é feita uma checagem de erros para então encaminhá-lo ao demultiplexador.

- Demultiplexador: os streams codificados consistem de pacotes identificados por um PID (Packet ID) numérico. O demultiplexador examina os identificadores, seleciona pacotes específicos, descriptografa e encaminha para um decodificador específico. 


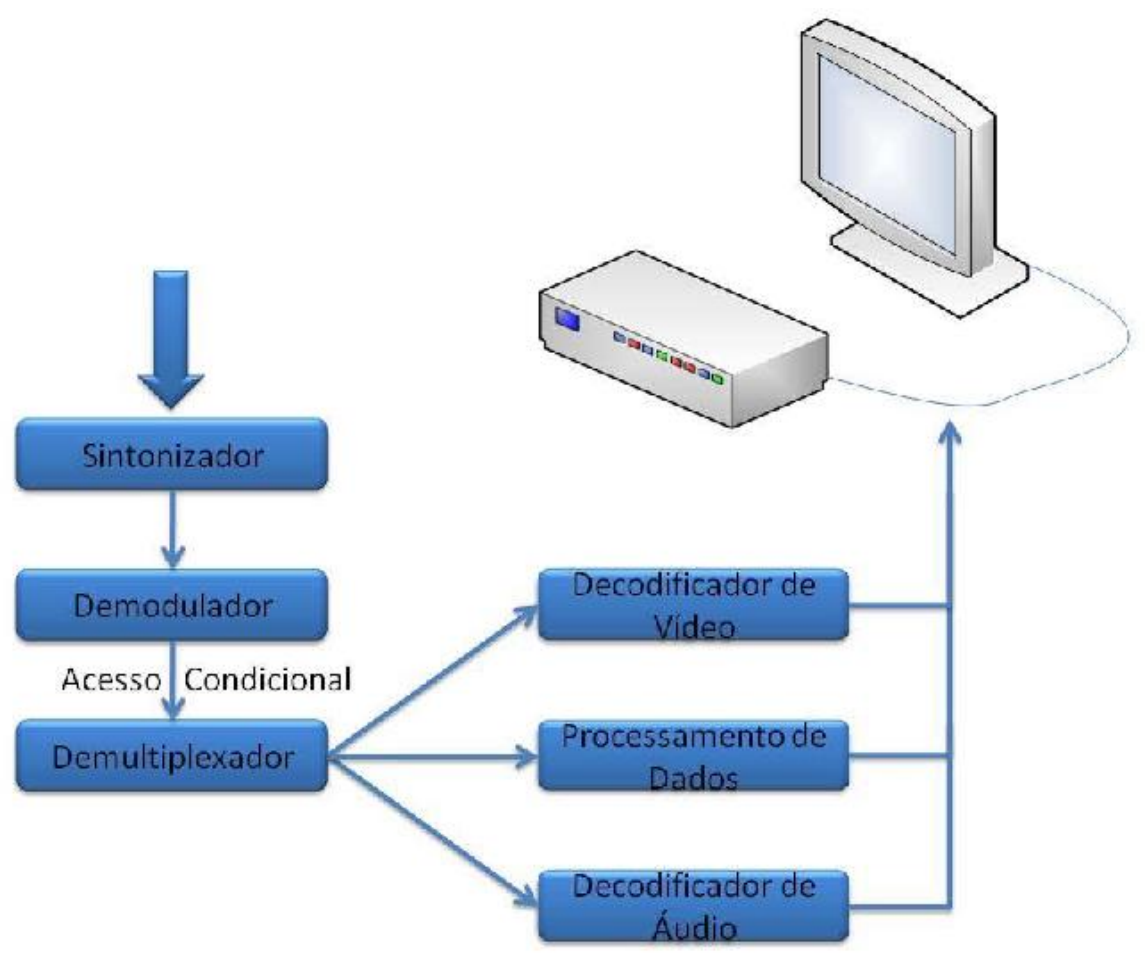

Figura 2.2: Arquitetura do Hardware, adaptado de (O'driscoll, 1999) (Montez e Becker, 2005).

- Decodificador de vídeo: transforma os pacotes de vídeo em sequiência de imagens a serem exibidas no monitor da TV.

- Decodificador de áudio: realiza a descompressão do stream de áudio e a saída pode ser um áudio em formato analógico (stereo/mono) ou digital.

- Processamento de dados: realiza o processamento dos dados e apresenta as interações disponíveis.

- Acesso condicional: garante acesso apenas aos canais que determinado telespectador tem permissão.

\section{Software}

Acima da camada de hardware, a arquitetura de um receptor digital é composta por três camadas de software conforme apresentado na Figura 2.3 (O’driscoll, 1999) (Montez e Becker, 2005) (ABNT, 2007).

- Middleware: a função do middleware é oferecer um serviço padronizado para a camada de aplicações, escondendo peculiaridades das camadas inferiores como, por exemplo, a tecnologia utilizada para a compressão e modulação do sinal digital. Ele permite que haja portabilidade das aplicações, de forma que possam ser transmitidas para outros receptores que adotam diferentes middlewares. 
- API (Applications Programming Interface): as APIs compõem a interface entre o middleware e as aplicações, de forma que os desenvolvedores das aplicações não precisem entrar em detalhes da implementação do middleware.

- Aplicaçõos interativas: são as aplicações recebidas, executadas em um receptor digital que oferecem aos usuários serviços específicos como governo eletrônico, interatividades agregadas a programas de TV e EPG (Eletronic Program Guide - Guia de Programação Eletrônica).

\section{Aplicações Interativas}

\section{API (Applications Programming Interface)}

\section{Middleware}

\section{Hardware}

Figura 2.3: Arquitetura do Software, adaptado de (O'driscoll, 1999) (Montez e Becker, 2005).

Assim como acontece com todo produto comercializado no mercado, inúmeros fabricantes disponibilizam inúmeros equipamentos com capacidades e características diferentes. A próxima Seção mostra os tipos de equipamentos receptores de sinais digitais de televisão.

\subsubsection{Tipos de Receptores}

Hoje no mercado encontram-se diversos tipos de equipamentos voltados para a recepção de sinal digital terrestre. A seguir são apresentados alguns tipos:

- One-seg: receptor utilizado para dispositivos móveis como automóveis, mini-TVs, notebooks e celulares. Seu sinal de vídeo é de 320 linhas, por isso não suporta HDTV. Além disso, dependem de requisitos mínimos como processador, memória e disco rígido para seu funcionamento.

- Receptor Digital: equipamento conectado a um aparelho televisor que tem a função de transformar o sinal sintonizado em conteúdo para ser exibido. Pelo fato de manipular dados além de áudio e vídeo, sua arquitetura é semelhante à de um computador convencional. Possui processador, memória, disco rígido (interno ou externo, o que permite que o usuário tenha controle sobre a programação recebida, podendo gravá-la, copiá-la e reproduzi-la quando quiser), interface Ethernet e outras opções de conectores. 
- Televisor com receptor integrado: equipamento televisivo com receptor digital integrado. Os fabricantes de televisores estão oferecendo cada vez mais recursos aos telespectadores como forma de se destacarem no mercado. Atualmente, muitos equipamentos apresentam funcionalidades como:

Internet@TV: permite acesso à Internet desde que haja conexão.

USB (Universal Serial Bus): permite a conexão de diversos periféricos como pendrives, discos rígidos externos e teclado.

Wireless: rede sem fio.

Full HD: resolução máxima que uma TV de alta definição alcança. Uma TV Full HD possui 1920 pixels de resolução horizontal por 1080 linhas de resolução vertical.

HDMI (High-Definition Multimedia Interface): interface totalmente digital de áudio e vídeo de alta definição.

Time Machine Ready: permite gravar a programação da TV Digital em horários estabelecidos pelo telespectador e reproduzi-lo quando quiser. Para o funcionamento dessa característica necessita-se de uma unidade de armazenamento.

DLNA (Digital Living Network Alliance): é uma rede que permite a transferência de dados entre muitas fontes como notebooks, máquinas digitais e celulares.

Ambilight: melhora a percepção do contraste, da cor e dos detalhes, projetando uma luz suave pelas bordas da TV.

O Minicom (Ministério das Comunicações) (Minicom, 2011) divulgou um comunicado onde afirma que a produção brasileira de TVs com o receptor digital integrado ultrapassou a marca de 6 milhões de aparelhos em 2010. A partir de 2011, de acordo ainda com o ministério, o número deve ser ainda maior, já que todas as televisões com tela maior ou igual a 26 polegadas terão de chegar às lojas com o receptor integrado.

- Media Center: a tecnologia digital e sua crescente aplicação em todas as áreas possibilitam imaginar um cenário em que um único equipamento poderia ser utilizado para suprir todas as necessidades pessoais de lazer, entretenimento, educação, cultura, informação e comunicação. Hoje já existem equipamentos com perfil semelhante a este, os Media Centers, também chamados "Tudo em Um", pois agregam vários dispositivos em apenas um. Esses equipamentos contemplam funcionalidades como: Home Theater, DVD, Blue Ray, computador pessoal, aparelho de som, receptor digital, além de permitir acesso à Internet.

No relatório dos consórcios do SBTVD os pesquisadores do middleware brasileiro (Ginga) propõem a divisão dos receptores de acordo com as suas funcionalidades, visando atender a diferentes segmentos da sociedade e suas necessidades (Tonieto, 2006). Assim, surgiu a seguinte classificação: 
- Tipo 1: Terminal zapper - suporta a troca de canais, exibição de vídeo e áudio em formato simples e exibição de legenda. Além disso, não suporta interatividade, nem mesmo local, canal de retorno e não contém middleware.

- Tipo 2: Terminal com aplicações residentes - suporta algumas interações, como acesso ao EPG (Eletronic Program Guide). Algumas aplicações como navegador Web e correio eletrônico poderiam vir instaladas nesse receptor, mas o conteúdo não seria transmitido pelo canal de interatividade (canal de retorno), e sim pelo próprio canal de difusão por iniciativa das estações de TV.

- Tipo 3: Com suporte a carga de aplicações transmitidas por broadcast - permite download e execução de aplicativos pelo canal de broadcast juntamente com fluxos de áudio, vídeo e dados. Não suporta canal de interatividade, apenas aplicativos com interatividade local.

- Tipo 4: Com canal de interatividade - com os mesmos recursos do Tipo 3, porém com canal de interatividade, o que permite o download de aplicações e o envio e recebimento de dados.

- Tipo 5: Com suporte a funcionalidades avançadas - com os mesmos recursos do Tipo 4, adicionando possibilidade de gravação do conteúdo, pausa, eliminação de comerciais, integração com dispositivos móveis, comando de voz, captura de vídeo e suporte a todas as funcionalidade do middleware.

Estes cinco tipos de terminais são então divididos em três categorias: Básica, contendo apenas o tipo 1, Intermediária, englobando os tipos 2 e 3, e Avançada, com os tipos 4 e 5.

Hoje no mercado existem diversos tipos de receptores digitais com diferentes configurações. Alguns receptores possuem limitações de memória, resolução gráfica e capacidade de armazenamento quando comparados aos computadores modernos. Outros, como os Media Centers, possuem todas ou quase todas as funcionalidades de um computador moderno. No entanto, é necessário que os desenvolvedores considerem as limitações de ambiente de cada tipo de equipamento antes de projetar suas aplicações. Eles devem considerar os diferentes tipos de receptores e os recursos que cada categoria suporta. Um estudo sobre os Receptores Digitais e Media Centers disponíveis comercialmente é apresentado no Capítulo 5.

Para que uma mesma aplicação enviada via broadcasting por uma emissora possa ser executada em todos os receptores existentes, faz-se uso de um middleware, que é uma camada de software entre as aplicações e o sistema operacional. No caso do Sistema Brasileiro de Televisão Digital, esse middleware é chamado de Ginga (Ginga, 2011). 


\subsection{Middleware Ginga}

Ginga é o nome do middleware do Sistema Brasileiro de Televisão Digital. O nome Ginga foi escolhido em reconhecimento à cultura, arte e contínua luta por liberdade e igualdade do povo brasileiro. Esse middleware é constituído por um conjunto de tecnologias padronizadas e inovações brasileiras e possui dois subsistemas principais interligados chamados Ginga-J e Ginga-NCL (Ginga, 2011).

- Ginga-J: provê uma infra-estrutura de execução de aplicações Java e extensões especificamente voltadas ao ambiente de TV (Ginga, 2011).

- Ginga-NCL: é um ambiente de apresentação multimídia para aplicações declarativas escritas na linguagem NCL e sua linguagem de script Lua (LUA, 2011). NCL é uma linguagem de aplicação XML (eXtensible Markup Language) com facilidades para a especificação de aspectos de interatividade, sincronismo espaço-temporal entre objetos de mídia, adaptabilidade, suporte a múltiplos dispositivos e suporte à produção ao vivo de programas interativos não-lineares (GingaNCL, 2011).

Os dois subsistemas, Ginga-J e Ginga-NCL, foram desenvolvidos, respectivamente, pelo LAViD (Laboratório de Aplicações de Vídeo Digital) da UFPB (LAViD, 2011) e pelo laboratório TELEMIDIA da PUC-Rio (TELEMIDIA, 2011).

Por ser código aberto, vários fabricantes de receptores digitais, televisores, celulares e de outros equipamentos desenvolveram, utilizando versões básicas do Ginga e em parceria com outras empresas, suas próprias plataformas de interatividade.

LG, Sony, Philips e Panasonic embarcaram o middleware StickerCenter (StickerCenter, 2011) em seus televisores. Já Samsung e Nokia desenvolveram suas próprias versões do Ginga, no entanto seus aplicativos foram desenvolvidos pela HXD.

Hoje não existe um padrão preestabelecido para o desenvolvimento das aplicações interativas. Com isso, emissoras de televisão como Globo, Bandeirantes, Record e SBT estão em fase de desenvolvimento e testes das primeiras aplicações. Porém, essa indefinição com relação a padronização das aplicações pode gerar um série de inconvenientes pois as aplicações podem ser apresentadas/ projetadas no aparelho televisor de diversas formas. Isso pode causar o mau funcionamento das aplicações além do descontentamento dos telespectadores.

\subsection{Aplicações e Interatividade}

As aplicações são programas desenvolvidos em linguagens declarativas e procedurais que, executadas em um receptor digital, oferecem serviços específicos aos telespectadores. Podem ser residentes no receptor ou serem transmitidas através do carrossel de dados. 
As aplicações são geradas pelo Provedor de Serviços Interativos (PSI), que pode ser um módulo da própria emissora ou ser uma empresa contratada por ela. Alguns exemplos de aplicações e opções de interatividade são:

- EPG (Eletronic Program Guide): fornece uma grade com a programação semanal de uma determinada emissora.

- T-Governo: aplicações de interesse da população e do governo, cidadania e interesses coletivos, como por exemplo: declaração e restituição de imposto de renda, consultas a saldos de FGTS (Fundo de Garantia por Tempo de Serviço), ações da Previdência Social, plebiscito, voto ou consulta à opinião popular.

- T-Commerce: comércio eletrônico através da TV. É a grande promessa de lucros da TV interativa, através da possibilidade de consultar catálogos de produtos ou até mesmo efetuar a compra, com a utilização do canal de retorno.

- Internet na TV: permite acesso à Internet usando a TV.

- TV Individualizada: permite a adaptação total da TV ao gosto do telespectador, como por exemplo, ângulo de exibição das imagens.

- On-Demand TV: diferentemente dos pay-per-views existentes hoje, onde é possível assistir os programas em diversos horários pré-determinados pela emissora, se trata de disponibilizar toda grade de programação, com exceção dos programas ao vivo, para serem vistos em qualquer horário escolhido pelo usuário.

- Walled Garded: portal contendo um guia de aplicações interativas. Esclarece ao usuário o que é possível fazer e o que está disponível.

- Console de jogos: permite o uso da TV para jogos.

- Serviços de tele-texto: são informações exibidas em forma de texto sobre algum programa como, por exemplo, sinopse de um filme ou os fatos principais que ocorreram no episódio anterior de uma novela.

- T-learning ou Educational TV: Aplicações de Ensino a Distância (EAD).

- Community TV: votação, veiculação de informações, suporte a comunidades virtuais, informações direcionadas a grupos específicos, como imigrantes, pais de alunos de um mesmo colégio.

- Global TV: programação internacional com tradução automática de língua.

- T-mail: correio eletrônico através da TV. Visa atingir a população sem acesso à Internet e complementa as demais aplicações. 
- TV saúde: serviços oferecidos por hospitais e postos, como marcação de consultas, programas de imunização, campanhas de esclarecimento e educação em saúde coletiva.

Em relação à interatividade, um sistema pode ser classificado de acordo com a sua forma de interação com o telespectador. É possível existir uma interação local onde áudio, vídeo e dados são enviados para o telespectador e nenhum dado é retornado para a emissora ou para o PSI. Esse sistema é chamado de Pseudo-Interativo (Neves, 2010).

Por outro lado, o telespectador pode receber uma aplicação e responder aos serviços na TV por meio de um canal de retorno, enviando dados para a emissora ou para o PSI. Esse sistema é chamado Interativo Pleno (Neves, 2010) (Santos Jr et al., 2010). Segundo (Barbosa e Soares, 2008), o sistema interativo pleno ainda pode ser dividido em unidirecional e bidirecional. A aplicação unidirecional permite somente o envio de dados do telespectador para a emissora de televisão, enquanto que a aplicação bidirecional permite tanto o envio de dados quanto o download de dados utilizados pelos aplicativos.

Segundo (Montez e Becker, 2005), estas formas de interatividade ainda são reativas, ou seja, reagem às opções determinadas pelo emissor. $\mathrm{O}$ autor sugere a criação de mais alguns níveis de interatividade para que ela se torne pró-ativa, permitindo que o usuário envie vídeos às emissoras e assim passe a ser também produtor do conteúdo transmitido, a exemplo do que acontece hoje na Internet com o advento da Web 2.0.

No entanto, para que haja essa troca de informações é necessário que exista um canal para a comunicação entre a emissora de televisão e os telespectadores, chamado Canal de Retorno.

\subsection{Canal de Retorno}

O canal de retorno é um meio de comunicação que possibilita a troca de informações (requisição e/ou envio) entre o telespectador e a emissora (Neves, 2010). De acordo com (Montez e Becker, 2005), muitas soluções podem ser adotadas como:

- Telefonia fixa: meio mais usado no país para o acesso à Internet, deve ser o carro chefe do acesso via TV, apesar de menos de um terço da população ter acesso a essa tecnologia. Também é a tecnologia de canal de retorno mais usada na Europa. A maior vantagem está na consolidação da tecnologia como meio de acesso à Internet. Além da baixa penetração, outro problema é a banda, que por restrições da própria tecnologia, não supera os $56 \mathrm{kbps}$. Apesar disso, pode ser amplamente utilizada para prover o acesso à Internet em banda baixa.

- ADSL (Assymetrical Digital Subscriber Line): uma alternativa para o aumento da taxa de transmissão de dados pelas linhas da telefonia fixa é a ADSL, que, por usar outra frequiência das chamadas telefônicas, pode chegar até a $8 \mathrm{Mbps}$. Com essa velocidade pode-se inclusive transmitir vídeos de alta definição ao vivo. 
- Rádio: a transmissão de dados por rádio pode ser uma boa alternativa para conjuntos ou condomínios residenciais, uma vez que os custos são excessivamente altos, praticamente inviabilizando essa tecnologia para usuários domésticos. Pode prover acessos em banda larga dependendo da capacidade e potência dos transmissores. A velocidade da transmissão dos dados varia usualmente entre 128 kbps e 2 Mbps.

- Satélite: alternativa que pode atingir todos os lares do país e que tem no preço o principal problema. Os custos de manutenção dos satélites e dos transmissores são excessivamente altos para permitir a ampla difusão desse tipo de acesso. Atualmente, a transmissão de dados para pessoas físicas é praticamente usada exclusivamente para acesso à telefonia celular em lugares afastados, onde as redes normais não são rentáveis por falta de assinantes.

- PLC (Power Line Communication): ainda em estudo, essa tecnologia promete revolucionar a transmissão de dados. O PLC permite usar a rede elétrica, presente em quase $100 \%$ dos lares, para transmitir dados. Seria o meio ideal para ser usado como canal de retorno na TV interativa. Porém, apesar do tempo de pesquisa, que já passa dos 30 anos, os resultados concretos ainda são mínimos. Há poucas perspectivas de uso dessa tecnologia em curto prazo.

As tecnologias de canal de retorno discutidas têm um problema em comum: atualmente nenhuma delas oferece preços ou condições de atingir as classes mais pobres da sociedade, foco da inclusão digital. Segundo Knight (Knight, 2007), a banda larga via ADSL (linha telefônica), cabo coaxial ou satélite custa caro no Brasil o que exclui a maioria da classe C e as classes D e E. Mas as novas tecnologias sem fio, Wi-Fi e WiMAX, permitem trazer a banda larga a custos bem mais baixos. Em algumas cidades digitais do Brasil, a Internet sem fio é um serviço público como a iluminação pública, como por exemplo, em Sud Mennucci, no Estado de São Paulo e Rio das Flores no Estado do Rio de Janeiro, paga com recursos públicos, grátis para quem está na área "iluminada" e tem computador aparelhado para esta tecnologia.

Outro fator importante é que o canal de retorno não deve ser homogêneo. Cada lugar ou usuário deve escolher a tecnologia que mais se adaptar às necessidades. Para lugares muito povoados e com alta densidade, o telefone, tanto fixo como móvel, pode ser a melhor alternativa. Por outro lado, em lugares pouco povoados ou completamente afastados dos grandes centros, sem acesso às redes de telefonia, o satélite deve ser a melhor saída. A própria rádio-difusão aparece como alternativa, uma vez que nessas regiões há espectro suficiente para ser usado como canal de retorno, o que já não acontece nas grandes cidades.

Isso leva a crer que a interatividade também não será homogênea, devendo ser personalizada segundo as necessidades do telespectador e respeitando as limitações da tecnologia escolhida para levar a resposta do usuário final. Vários níveis de interatividade deverão existir nos mesmos programas ou nas mesmas emissoras, para evitar a perda de telespectadores. Para quem não tiver canal de retorno, o que provavelmente vai representar uma boa parte da população devido aos problemas 
apontados anteriormente, poucas alterações devem ocorrer em relação a interatividade. A televisão será apenas uma evolução tecnológica.

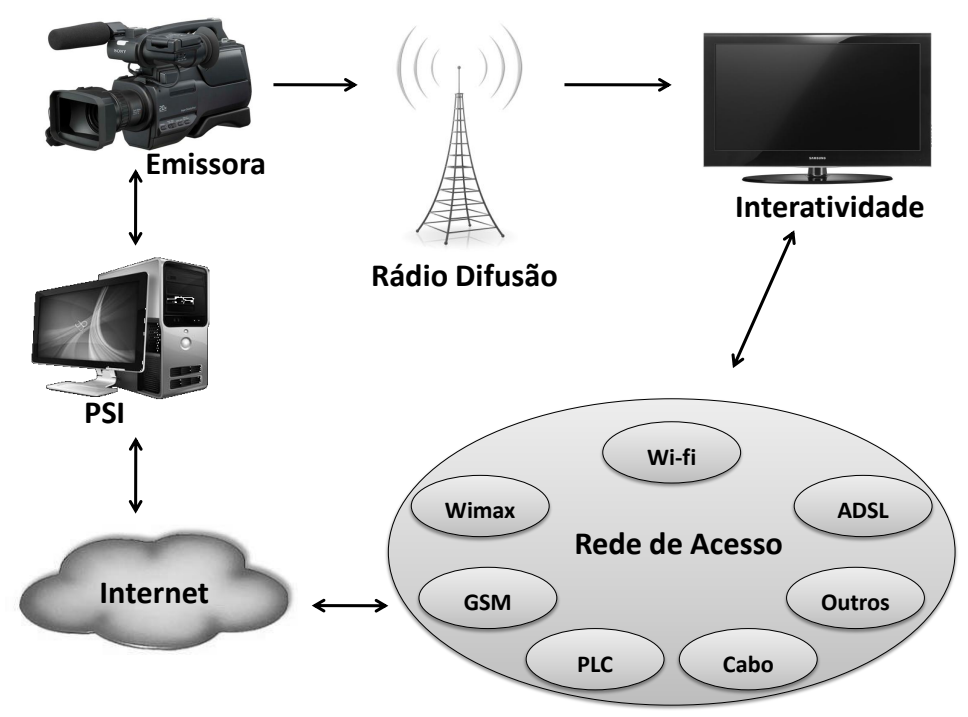

Figura 2.4: Emprego do Canal de Retorno em um Sistema de Televisão Digital Interativa (DTV, 2011).

O fato é que, até o presente momento, nenhum padrão foi estabelecido dificultando a implantação do sistema interativo pleno. A Figura 2.4 apresenta o emprego do canal de retorno em um Sistema de Televisão Digital Interativa. Uma vez que uma aplicação é recebida via broadcasting e executada pelo receptor, pode-se utilizar esse canal de retorno para o envio de informações. É possível ainda que o canal de retorno seja utilizado como um meio auxiliar para a recepção de dados da emissora. Esses dados conforme dito anteriormente são enviados pelo Carrossel de Dados.

\subsection{Carrossel de Dados}

Com o advento da Televisão Digital tornou-se possível transmitir qualquer tipo de dados, desde que sejam digitais. Essa transmissão de dados junto com o fluxo de áudio e vídeo é conhecida como datacasting (Montez e Becker, 2005), onde há o encapsulamento e a difusão de dados dentro de um fluxo de transporte, junto com outros fluxos elementares de áudio e vídeo. O datacasting pode ser classificado segundo o seu grau de acoplamento com o fluxo de áudio/vídeo difundido:

- Datacasting fortemente acoplado: é aquele em que o fluxo de dados está fortemente relacionado com o áudio e o vídeo. Um exemplo disto é o caso de um show em que aparecem as cifras da música e elas devem estar sincronizadas com o vídeo e o áudio para que apareça a cifra certa no momento exato do fluxo.

- Datacasting fracamente acoplado: é aquele onde os dados estão relacionados ao áudio e ao vídeo, mas não são completamente sincronizados. Dessa forma, é possível escolher o 
melhor momento para acessar esses dados, sem prejudicar a compreensão da informação principal. Por exemplo, na difusão de um material educacional suplementar a um vídeo, onde o telespectador pode escolher visualizar essa informação antes, durante ou depois de assistir o vídeo.

- Datacasting desacoplado: é aquele onde o dado pode ser enviado em um fluxo separado, totalmente independente de outros fluxos. As informações podem fluir entre os telespectadores e o provedor de forma equivalente ao que ocorre na Internet, quando um usuário navega na $W e b$.

A forma padronizada em TV digital para datacasting é a do Carrossel de Dados. Sua função é permitir a instalação dinâmica, no receptor do telespectador, de uma cópia de um sistema de arquivos produzido no estúdio de dados, localizado na emissora (Fernandes et al., 2004). Este sistema de arquivos persiste no receptor apenas enquanto o serviço estiver sintonizado. $\mathrm{O}$ nome carrossel se deve ao fato de que os fluxos de dados que geram o sistema de arquivos precisam ser retransmitidos ciclicamente, a fim de que seja possível a um receptor que acabou de sintonizar o serviço, receber este sistema de arquivos, mesmo após o início da difusão. Com o envio periódico de dados, o receptor do telespectador apenas aguarda o próximo envio quando precisar de uma determinada informação adicional. Todos os tipos de arquivos, tais como páginas Web, imagens JPEG, músicas em MP3, programas de computadores e bases de dados, podem ser transmitidos dessa forma. Guias de programação eletrônica (EPG), aplicativos em Java (denominados Xlets) e softwares novos para o receptor são os exemplos mais citados de uso para essa tecnologia.

A implementação do carrossel de dados em fluxos de transporte MPEG-2 é baseado no protocolo DSM-CC (Digital Storage Media Command and Control Protocol). O DSM-CC foi criado originalmente visando uma forma de suportar a entrega de vídeos sob demanda usando um fluxo de transporte MPEG-2.

Os arquivos a serem transmitidos pela central de produções no protocolo DSM-CC, fazem parte de uma aplicação, que é transmitida em um fluxo individualmente identificado. Os arquivos são agrupados em módulos, aos quais estão associadas prioridades de retransmissão. O Gerador de Carrossel gera continuamente um stream contendo os módulos a transmitir, sendo que os módulos de maior prioridade são transmitidos com maior frequiência.

\subsection{Considerações Finais}

A implantação do Sistema Brasileiro de Televisão Digital irá promover diversas vantagens aos telespectadores como, por exemplo, melhor qualidade de áudio e vídeo, interatividade, entre outros benefícios. No entanto, para que os telespectadores usufruam desses benefícios é necessária a aquisição de um receptor digital. 
Os receptores digitais apresentam algumas características similares àquelas encontradas em um computador convencional, permitindo a execução de aplicações. Desta forma, a televisão poderá ser um forte instrumento para a promoção da inclusão digital no país.

Analisando a natureza computacional desses equipamentos é possível que, em determinado momento, os recursos computacionais existentes nos receptores encontrem-se ociosos. Sendo assim, torna-se interessante o compartilhamento de tais recursos para que possam ser empregados em tarefas que exijam uma grande potência computacional, caracterizando uma grade computacional de receptores digitais. O próximo Capítulo apresenta as principais características de uma grade computacional. 


\section{Grades Computacionais}

\subsection{Considerações Iniciais}

O termo grade computacional é definido como um supercomputador virtual, composto dinamicamente por recursos geograficamente distribuídos e interconectados através da Internet. Surgiu na metade dos anos 90 para denotar um sistema distribuído em que os recursos computacionais (podendo variar desde processadores e discos rígidos até licenças de software) geograficamente distribuídos e sob administrações independentes podem ser compartilhados entre os participantes da grade computacional. Esse compartilhamento considera a real necessidade de seus usuários de maneira transparente, onde o usuário não sabe o que efetivamente está acontecendo.

O agrupamento de recursos distribuídos em uma grade computacional torna o sistema poderoso o bastante para contribuir para a solução, de forma colaborativa, de diversos problemas sem a necessidade dos participantes adquirirem novos equipamentos. Ao redor de todo o mundo é possível encontrar um grande número de computadores cuja capacidade não é totalmente explorada. Dessa forma, o agrupamento dos percentuais de ociosidade desses equipamentos pode oferecer uma potência computacional considerável para a solução de muitos problemas (Teixeira, 2009) (Schwiegelshohn et al., 2010).

Ian Foster (Foster et al., 2002) traduz os conceitos de grade da seguinte forma: Compartilhamento de recursos coordenados e resolução de problemas em organizações virtuais multiinstitucionais dinâmicas. Segundo ele, a tecnologia aplicada em uma grade computacional permite agregar recursos computacionais dispersos e variados em um único supercomputador virtual, acelerando a execução de várias aplicações paralelas. 
As grades computacionais só se tornaram possíveis nos últimos anos devido à grande melhoria em desempenho e redução de custos, tanto de redes de computadores, quanto de microprocessadores. Por meio de grades computacionais é possível explorar as potencialidades das redes de computadores, com o objetivo específico de disponibilizar camadas virtuais que permitam a um usuário ter acesso a aplicações altamente exigentes, bem como aderir a comunidades virtuais de grande escala, com uma grande diversidade de recursos de computação e de repositórios de informações (Baker et al., 2002).

Além disso, grades podem ser consideradas como um conjunto de serviços distribuídos pela Internet que visa compartilhar recursos computacionais, como armazenamento e poder de processamento, entre um conjunto de instituições que são chamadas de Organizações Virtuais (OV) ou Federações.

As organizações virtuais podem ser compostas para atender a diversos tipos de trabalhos e podem variar em muitos aspectos, tais como: tamanho, finalidade à qual se destinam, escopo, duração, entre outros (Foster et al., 2002). Os participantes de uma federação definem regras como: quem pode usar os recursos, quais recursos podem usar, quando e como. Traçando uma comparação com a Internet, a entidade organização virtual seria semelhante a uma página, todavia com a possibilidade de prover serviços solicitados pelo usuário.

Esses serviços são executados em um grande computador virtual, com uma forte integração de servidores, discos e outros recursos capazes de compartilhar recursos de forma rápida e de fácil gerenciamento (Dantas, 2005). A próxima Seção apresenta as características da arquitetura de grades computacionais.

\subsection{Arquitetura de Grades}

A arquitetura de uma grade computacional fornece mecanismos para o compartilhamento de recursos, atendendo aspectos como interoperabilidade e segurança (Foster et al., 2001).

Durante anos de pesquisa nessa área, foi produzido um considerável consenso quanto aos requisitos e à arquitetura de uma grade computacional (Teixeira, 2009) (Foster et al., 2002) (Schwiegelshohn et al., 2010). Muitos protocolos para troca de mensagens entre aplicações foram propostos, assim como diversas API's com o intuito de oferecer meios mais simples e produtivos para a construção de uma grade computacional.

Assim, a arquitetura de uma grade computacional pode ser organizada em um modelo de camadas. Esse modelo pode ter sua forma comparada a de uma ampulheta, pois as camadas internas possuem um número menor de protocolos e API's. A Figura 3.1 ilustra esse modelo (Foster et al., 2001) (Teixeira, 2009).

A camada Ambiente acomoda os diversos recursos da grade que são compartilhados através da utilização de protocolos. Tais recursos podem ser tanto recursos físicos (unidades de disco, 
processadores, entre outros) como também recursos lógicos (como sistemas de arquivo e licenças de software).

Os componentes da camada Ambiente oferecem protocolos e mecanismos que implementam as operações fornecidas pelos recursos. Esses protocolos e mecanismos podem ser fornecidos pelo fabricante do recurso ou até mesmo disponibilizados pelo middleware da grade computacional.

A camada Conectividade e Segurança define um conjunto básico de protocolos para atender aos requisitos de comunicação e autenticação de uma operação da grade. Essa camada é composta por vários protocolos como, por exemplo, IP (Internet Protocol), ICMP (Internet Control Message Protocol), TCP (Transmission Control Protocol), UDP (User Datagram Protocol), entre outros.

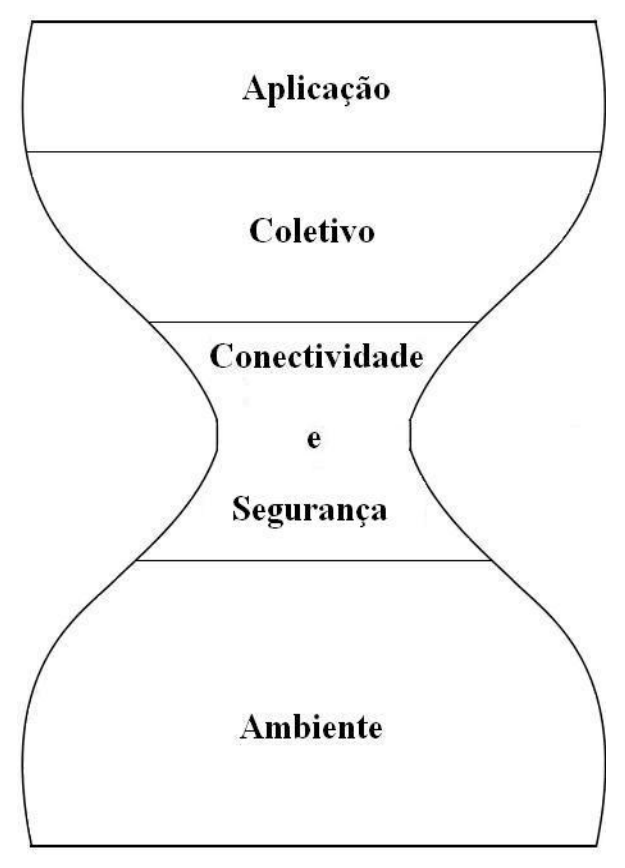

Figura 3.1: Modelo de Camadas de uma Grade Computacional (Foster et al., 2001) (Teixeira, 2009).

Os aspectos de segurança são implementados por mecanismos de autenticação e criptografia. Em uma organização virtual os mecanismos de autenticação devem oferecer, entre outras, as seguintes características:

- Único Log-on: após o usuário efetuar um processo de autenticação para utilizar um determinado recurso da grade computacional, deve ser possível que ele utilize diversos outros recursos sem a necessidade de nova autenticação;

- Delegação: é necessário que um usuário possa atribuir a um determinado programa os seus direitos de maneira que esse atue no sistema em seu nome. Esse programa também deve ser capaz de atribuir esses direitos a outro programa; 
- Integração com várias soluções locais de segurança: vários sistemas podem utilizar sistemas locais de segurança e é necessário que os mecanismos da grade sejam capazes de interagir com eles.

A camada Conectividade e Segurança utiliza os mecanismos da camada Ambiente para realizar de forma segura as operações sobre um recurso compartilhado (como por exemplo: negociação, monitoração, contabilização, entre outros). Os protocolos existentes na camada Conectividade e Segurança permitem:

- Obtenção de Informações: onde os protocolos são utilizados para obter informações sobre um determinado recurso;

- Gerenciamento: onde os protocolos são responsáveis pela negociação de utilização de um determinado recurso incluindo aspectos como qualidade de serviço e operação a ser executada.

A camada Coletivo possui protocolos e API's que implementam um conjunto de operações sobre um conjunto de recursos. Os componentes dessa camada implementam serviços como:

- Serviços de diretório;

- Serviços de alocação conjunta e agendamento de recursos;

- Serviços de monitoramento e diagnóstico;

- Serviços de pesquisa de software;

- Serviços colaborativos;

- Sistema de programação.

Por fim, na camada Aplicação são encontradas as aplicações propriamente ditas que operam utilizando recursos existentes em uma grade computacional.

No entanto, em uma grade computacional, assim como em outros sistemas distribuídos, a padronização é uma questão muito importante. Ela permite que soluções desenvolvidas por diferentes instituições ou empresas possam interagir entre si. Com o intuito de padronizar os trabalhos realizados para grades computacionais algumas especificações são definidas (Dantas, 2005) (Teixeira, 2009). 


\subsection{Especificações OGSA, OGSI e WSRF}

A especificação OGSA (Open Grid Services Architecture) define que todos os recursos compartilhados são representados por serviços denominados Serviços de Grade. Ela apresenta uma visão ampliada de como esses serviços devem ser para atender aos requisitos básicos do sistema. A OGSA não descreve, detalhadamente, como um serviço da grade deve ser, pois ela descreve a arquitetura de uma grade computacional orientada a serviços de uma forma global. Já a especificação OGSI (Open Grid Service Infrastructure) tem essa finalidade. Ela é responsável por detalhar a construção desses serviços esboçados pela OGSA (Dantas, 2005).

Com a evolução da tecnologia de serviços Web, alguns aspectos da OGSI precisaram ser reanalisados. Assim, surgiu a especificação WSRF (Web Services Resource Framework) (WSRF, 2011) que refina a OGSI e divide a especificação em outras menores, agrupadas em uma mesma família. Além disso, ela apresenta outras funcionalidades necessárias como, por exemplo, a capacidade de um serviço Web armazenar seu estado entre diversas invocações. Para isso, a WSRF disponibiliza o WS-Resource que é definido como a composição de um serviço Web e um recurso capaz de manter seu estado (WSRF, 2011). Tal recurso é expresso como um documento XML que pode ser criado, endereçado, acessado, monitorado e destruído através de mecanismos convencionais existentes na tecnologia de serviços Web.

De forma a efetuar uma simples analogia, é possível comparar a construção de um serviço de grade com a construção de uma casa. O primeiro passo quando se deseja construir uma casa é procurar um arquiteto de maneira que esse efetue um projeto dando uma visão ampla de como a casa será depois de pronta. No entanto, esse projeto não traz consigo detalhes de como essa casa deve ser construída. Isso exige que um engenheiro seja consultado de maneira a criar um projeto mais detalhado definindo como deve ser a estrutura dessa casa, a instalação elétrica e hidráulica, entre outros. Assim, na analogia apresentada, a OGSA faz um papel semelhante ao do arquiteto e a OGSI ao engenheiro (Globus, 2011).

\subsection{Escalonamento em Grades Computacionais}

O escalonamento de tarefas de uma grade computacional trata-se do processo de escalonar para recursos computacionais distribuídos por diferentes localidades, um conjunto de aplicações originadas de usuários, com o objetivo de maximizar a utilização do sistema. Isso, exige que o mecanismo de escalonamento seja bastante robusto e eficaz. Esse processo envolve três fases principais:

- Descoberta de recursos;

- Seleção do sistema;

- Execução do trabalho. 
O escalonamento de tarefas pode ser feito baseado em requisitos tais como a quantidade de memória, de processamento, qualidade de serviço ( $\mathrm{QoS}$ - Quality of Service), largura de banda da rede, quantidade de computadores, tipo do sistema operacional, topologia de rede, tipo de memória (compartilhada ou distribuída), dentre outros (Rodamilans, 2009).

No escalonamento de processos em um sistema operacional, o escalonador pode selecionar os processos que estão na memória, os que estão na área de swap, os que vão consumir menos tempo de processamento, ou os processos que tiverem prioridades mais altas. Pode-se citar algoritmos como FCFS (First Come, First Served), onde o primeiro processo a chegar é o primeiro a ser encaminhado para o processamento e RR (Round Robin) que fornece uma quantidade de tempo do processador para cada processo, permitindo assim o compartilhamento de tempo (time sharing).

Em sistemas distribuídos, uma característica importante no escalonamento é saber para qual recurso a tarefa será encaminhada. Isto envolve características dos processos, como o uso intensivo de computação (CPU) e de E/S; da rede, como largura de banda; dos recursos, a exemplo da quantidade de memória, capacidade de processamento, quantidade de recursos; dos softwares a serem utilizados, como sistema operacional, aplicações, compiladores. Em geral, o cliente solicita recursos ao escalonador, e este indica quais recursos o cliente pode utilizar.

Com o objetivo de atender às necessidades de sistemas distribuídos, tornou-se necessária a criação de novos escalonadores, chamados de escalonadores globais, em contraste aos escalonadores locais de sistemas operacionais convencionais. Recebem esse nome, pois em um ambiente distribuído existem diversos recursos disponíveis e com isso sua tarefa agora passa a ser escalonar processos entre um conjunto acoplado de máquinas, diferente de um sistema convencional, onde apenas existe um recurso. Um escalonamento é feito objetivando diversas metas de desempenho, por isso os escalonadores globais agregaram a função de escolher quando e quais processos têm acesso a quais recursos do sistema (Maheswaran et al., 1999) (Silberschatz et al., 2001). Entre as metas existentes, as principais são:

- Aumentar o throughtput do sistema: também chamado de vazão do sistema, é a medida feita a partir do número de processos finalizados por unidade de tempo.

- Diminuir o tempo de resposta: tal medida é definida pela diferença entre o momento de término da execução da tarefa e seu instante de chegada na fila de processos, ou seja, essa medida é a soma dos tempos gastos em fila de espera por recursos e na execução propriamente dita dos processos.

- Aumentar a utilização de recursos: o escalonador pode fazer com que os recursos do sistema, tais como CPU, memória ou rede, sejam utilizados ao máximo, mesmo que para atingir tal meta seja necessário esquecer outros critérios.

- Balancear a carga do sistema: consiste em não subutilizar recursos enquanto outros estão trabalhando em sua capacidade máxima. A intenção é distribuir os processos para os recursos de acordo com a capacidade dos mesmos. 
A Figura 3.2 ilustra o relacionamento entre usuário, escalonador e recursos (Maheswaran et al., 1999).

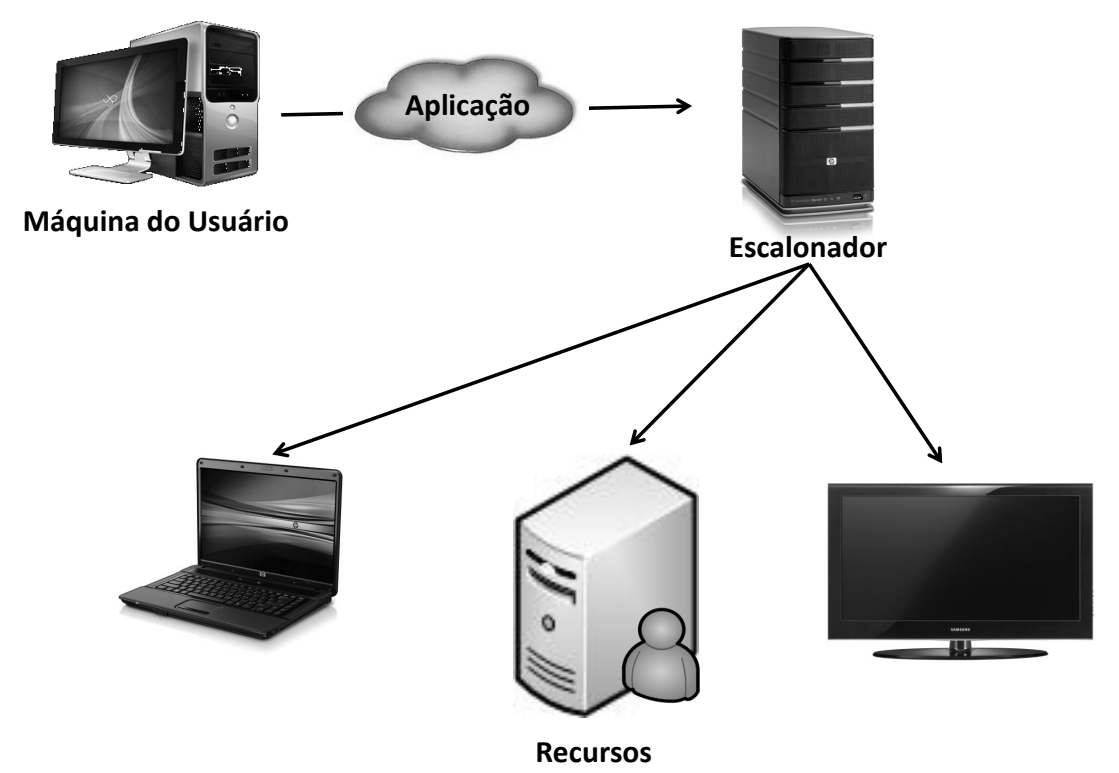

Figura 3.2: Relacionamento entre escalonador, recursos e usuários (Maheswaran et al., 1999).

As grades computacionais utilizam recursos ociosos de máquinas pertencentes ao seu domínio, as quais podem apresentar diferentes configurações (Foster e Kesselman, 2004). Essa característica resulta em alguns problemas inexistentes em sistemas de um único processador, como:

- Grande quantidade de recursos: a grande disponibilidade de recursos torna-se um problema para o escalonador, que pode se tornar um gargalo do sistema, pois ele deve escolher de forma apropriada, qual recurso irá executar determinado processo.

- Grande heterogeneidade de recursos: máquinas pertencentes à grade podem apresentar configurações heterogêneas. Entre as configurações, as principais são poder de processamento, interconexão e sistema operacional.

- Alto compartilhamento de recursos: a variação de carga nas máquinas causada pela submissão de novos processos ao sistema é proporcional ao número de usuários da grade, isto é, quanto mais usuários, maior será a variação de carga do sistema, e isso pode fazer com que as políticas que não prevêem tal fato atinjam um resultado negativo.

- Movimentação e consistência de dados: em grades deve-se evitar a submissão de aplicações que realizem muita comunicação, pois a sobrecarga da rede de interconexão dos recursos pode causar prejuízos ao escalonamento.

Diversos desafios de escalonamento em grades computacionais, assim como alguns algoritmos, são apresentados em (Andrieux et al., 2004) (Dong e Akl, 2006) (Zhu, 2007) (Wieczorek et al., 
2009) (Kosar e Balman, 2009) (Leal et al., 2009) (Tao et al., 2009). Dentre os desafios discutidos nestes trabalhos, cabe destacar a heterogeneidade dos recursos, a interconexão de computadores em rede com a utilização de diversos protocolos e também as diferentes larguras de banda entre eles. Os computadores que compõem a grade possuem diferentes configurações, seja no nível do hardware, como, por exemplo, a quantidade de memória, capacidade de processamento, quantidade de processadores; seja no nível de software, como diferentes sistemas operacionais, sistemas de arquivos, aplicativos de gerenciamento, aplicações dos usuários. Esta diversidade aumenta a complexidade do escalonamento.

Outro desafio está relacionado à autonomia. As instituições possuem suas próprias políticas de escalonamento dificultando a predição da tarefa em um determinado domínio. A prioridade que a instituição determina para as tarefas também influencia no tempo de espera e de execução das tarefas. Os escalonadores de grades podem não ter todas as informações dos recursos, o que dificulta um escalonamento efetivo.

O dinamismo da grade implica em outro desafio. Pelo fato das instituições controlarem os próprios recursos, estes podem ficar temporariamente indisponíveis ou semidisponíveis para o seu uso na grade. Um computador pode ficar indisponível durante um determinado tempo não estabelecido previamente, a largura de banda disponível pode variar com o tráfego da rede, ou seja, como os recursos não são dedicados, as informações sobre os recursos tornam-se dinâmicas, e o escalonamento, mais complexo.

Nos sistemas tradicionais, as aplicações normalmente estão localizadas no mesmo domínio, assim como, os dados de E/S. Em uma grade, os dados de entrada podem estar em um domínio, a aplicação que irá executá-los em outro, e a saída gerada por essa aplicação pode ser armazenada em outro domínio. Transferências de grandes volumes de dados implicam em tempo e consumo dos recursos, sendo necessário outro tipo de solução, como por exemplo, escalonar as aplicações para o domínio onde estão localizados os dados. Esse tipo de decisão dificulta ainda mais o escalonamento em uma grade computacional. A seguir são apresentadas algumas políticas de escalonamento para grades.

\subsection{Políticas de Escalonamento para Grades}

A realização de um escalonamento nada mais é que a aplicação de regras a um conjunto de tarefas e recursos, utilizando ou não informações do sistema. Deve-se adotar a política de escalonamento correta para cada aplicação distinta. Aplicações Bag-of-tasks (aplicações independentes) facilitam o escalonamento, por sua característica de independência entre as tarefas, o que permite o uso de políticas baseadas em apenas alguns dados do sistema, raramente necessitando de informações sobre a infra-estrutura da grade, como latência da rede e largura de banda. As políticas podem ser estáticas ou dinâmicas, a diferença está no momento em que o escalonamento é feito. 
Se ele acontecer no momento da compilação, então é dito estático, caso contrário é chamado de dinâmico.

$\mathrm{Na}$ literatura são investigados diferentes tipos de heurísticas de escalonamento para tarefas independentes em ambientes distribuídos e heterogêneos. Algumas possíveis heurísticas são apresentadas a seguir, de acordo com (Ali et al., 2002) (Casanova et al., 2000) (dos Santos Neto, 2004) (Silva et al., 2004) (Dong e Akl, 2006) (Munir et al., 2007):

- WQR (WorkQueue with Replication): é uma versão baseada na política WQ (WorkQueue) que inclui a utilização de réplicas. Se todas as tarefas já estão alocadas e existe um recurso ocioso, são criadas réplicas da tarefa original que são submetidas para os recursos ociosos. Quando a tarefa original é finalizada, as suas réplicas também são e o contrário também é válido.

- Max-Min (Max-Min heuristic): é baseada na idéia de atribuir as maiores tarefas para as melhores máquinas e em seguida executá-las em paralelo com outras tarefas. Isto conduz para o melhor balanceamento de carga e melhor tempo de execução total.

- Min-min (Min-min heuristic): ao contrário da Max-Min, essa heurística atribui as menores tarefas às melhores máquinas, o que tende a resultar em um maior desbalanceamento de carga entre os recursos quando comparada com a Max-Min. Pode-se dizer, porém, que ela visa um alto throughput, pois os melhores recursos são liberados mais rapidamente, podendo assim executar novas tarefas.

- OLB (Opportunistic Load Balancing): a estratégia é atribuir cada tarefa para a próxima máquina disponível sem considerar o tempo de processamento estimado naquela máquina.

- MET (Minimum Execution Time): considera apenas o tempo de processamento estimado de cada tarefa em uma máquina e seleciona a máquina com o tempo de execução menor.

- MCT (Minimum Completion Time): atribui cada tarefa para as máquinas com o menor tempo de execução.

- XSufferage: o algoritmo XSufferage é baseado nas informações sobre o desempenho dos recursos ao associar tarefas aos processadores. O XSufferage é uma extensão do Sufferage, ou seja, seu fundamento é a determinação de quanto uma tarefa estaria sendo prejudicada caso não fosse escalonada para o processador que a processaria da forma mais eficiente. Portanto, o algoritmo Sufferage dá preferência às tarefas dependendo do valor que mede o prejuízo de cada uma delas. Esse valor é definido como a diferença entre o melhor tempo de execução previsto para a tarefa e o segundo melhor, considerando todos os processadores da grade. Ele considera apenas os recursos livres no momento do escalonamento da tarefa, caso contrário, os recursos de melhor conexão de rede e os mais rápidos receberiam todas as tarefas, estando em uso ou não. 
Para estudar o comportamento das políticas de escalonamento de tarefas existentes para grades computacionais, torna-se interessante o uso de simuladores devido à complexidade e aos custos para construir e operar os testes em um ambiente real desse porte. A próxima Seção apresenta um estudo sobre os simuladores existentes para grades computacionais.

\subsection{Simuladores de Grades Computacionais}

A análise do comportamento de grades computacionais pode ser feita através do uso de simulações ou por meio de experimentos feitos em ambientes de grades reais. Experimentos em plataformas reais podem resultar em dados confiáveis, mas apresentam uma série de limitações como escalabilidade, mínima possibilidade de reconfiguração de software, dependência a um conjunto de condições reais, entre outros. Com isso resultados obtidos a partir de plataformas reais são difíceis de serem replicados e dificilmente representarão dados de outras plataformas.

Os simuladores, por executarem um modelo do sistema real, independem da plataforma de execução e permitem abordar comportamentos específicos de um sistema distribuído. Por meio das ferramentas de simulação, pode-se avaliar e comparar o desempenho de diferentes algoritmos em diferentes cenários. Várias ferramentas foram desenvolvidas com esse propósito, entre elas SimGrid, Bricks, MicroGrid, GangSim e GridSim. As próximas Seções apresentam as características principais desses simuladores. Neste trabalho será utilizada a ferramenta de simulação GridSim devido à sua simplicidade na instalação, documentação detalhada e pelo grande número de trabalhos que utilizam esse simulador.

\subsubsection{SimGrid}

O SimGrid fornece um conjunto de ferramentas e funcionalidades para a simulação de aplicações distribuídas em ambientes heterogêneos distribuídos. Ele provê alguns ambientes de programação construídos sobre um único núcleo de simulação. Cada ambiente é destinado a um usuário alvo (Legrand et al., 2003).

Neste simulador a potência computacional é definida como o número de unidades de trabalho por unidade de tempo. Ele não faz distinção entre transferência de dados e computação, ambos são vistos como tarefas e é de responsabilidade do usuário garantir que tarefas que exigem processamento sejam escalonadas para os processadores e a transferência de dados para conexões de rede. Além disso, ele assume que todas as tarefas são $C P U$-bound e que a transferência de dados são bandwidth-bound (Casanova, 2001).

A implementação das políticas de escalonamento é feita através de programação, com a utilização de uma API em linguagem C. Essa API permite manipular tipos de dados para recursos e para tarefas. Um recurso é descrito pelo nome, um conjunto de métricas relacionadas a desempenho e constantes, enquanto que uma tarefa é descrita pelo nome, custo e estado. 


\subsubsection{Bricks}

O Bricks é um sistema de avaliação de desempenho que permite a análise e comparação entre várias políticas de escalonamento em uma grade computacional de alto desempenho. Ele simula vários comportamentos de grades como o comportamento de redes e algoritmos de escalonamento de recursos. Consiste de dois componentes: o Global Computing Environment que modela a grade e o Scheduling Unit que coordena o comportamento da simulação das grades computacionais. Os modelos Bricks do Global Computing Environment consistem de três entidades (Sulistio et al., 2004):

- Clientes: representam as máquinas dos usuários que têm tarefas para executar;

- Servidores: representam os recursos disponíveis para executar as tarefas;

- Redes: representa a rede entre os clientes e servidores. Os eventos das entidades formam a comunicação necessária para conduzir a simulação.

O Bricks é orientado a objetos e implementado em linguagem Java. A unidade de escalonamento usa interfaces Java para suportar vários componentes e algoritmos de escalonamento. Ele permite que o usuário configure os parâmetros do Global Computing Environment. Com isso, ele pode usar o construtor Bricks para testar e avaliar uma variedade de simulações de uma forma determinística baseada em estatísticas coletadas (Takefusa, 2001). Nenhum trabalho atual foi encontrado em desenvolvimento para o Bricks, uma vez que não está disponível para download.

\subsubsection{MicroGrid}

O MicroGrid implementa a infra-estrutura de uma grade virtual visando executar uma aplicação Globus para suportar um modelo sistemático e evolutivo de middleware, aplicações e serviços de redes para uma grade computacional (Sulistio et al., 2004). Ele modela a infra-estrutura do middleware Globus Grid, e visa suportar uma simulação escalável de aplicações de uma grade usando uma ampla variedade de clusters. O MicroGrid fornece um ambiente de software que emula as aplicações para executarem com APIs e permite que o usuário MicroGrid configure os atributos de desempenho de recursos da grade.

Essa ferramenta modela recursos de uma grade como entidades computacionais e essas, por sua vez, interagem por meio de entidades de comunicação. O MicroGrid adota a programação estruturada e é implementado em linguagem C. O ambiente de projeto do MicroGrid assemelha-se a uma linguagem já que ele fornece um conjunto limitado de comandos para o usuário, que permite a fácil emulação de aplicações Globus em um ambiente baseado em simulação. Nenhuma interface visual é fornecida pelo MicroGrid e o usuário tem que modificar manualmente o Makefile de uma aplicação Globus para adicionar um link para que seja executada a simulação (Song et al., 2000). 


\subsubsection{GangSim}

O GangSim (Dumitrescu e Foster, 2005) foi construído para auxiliar estudos de escalonamento em grades computacionais. Tais estudos visam avaliar o impacto das políticas de alocação de recursos adotadas por páginas e organizações virtuais (OV). Sendo assim a ferramenta simula grandes grupos de usuários. Em grades computacionais, uma OV é definida como um conjunto de instituições que compartilham recursos de forma coordenada e que atendem a determinados requisitos (Foster et al., 2001). Estes requisitos envolvem um único método de autenticação, autorização, acesso aos recursos, descoberta de recursos, entre outros. Esse simulador permite combinar componentes da simulação com instâncias da ferramenta de monitoração OV-Ganglia executando em recursos reais.

A especificação da carga de trabalho, que caracteriza o conjunto de tarefas a serem simuladas, e do ambiente da grade é realizada por meio de ferramentas específicas oferecidas pelo GangSim. A modelagem do programa de simulação baseia-se na especificação das políticas de alocação de recursos nas páginas e nas OVs.

\subsubsection{GridSim}

O GridSim suporta a modelagem e simulação de recursos heterogêneos de uma grade computacional (com tempo ou espaço compartilhado), bem como os usuários e aplicações. Ele fornece primitivas para a criação de tarefas, mapeamento das tarefas nos recursos, e seu gerenciamento de modo que os escalonadores de recursos podem ser simulados para estudar os algoritmos de escalonamento envolvidos.

O toolkit de modelagem e simulação GridSim (Buyya e Murshed, 2002) dá suporte a um conjunto de características de recursos heterogêneos, tanto para um como para múltiplos processadores, máquinas com memória compartilhada e distribuída tais como computadores pessoais, de trabalho e clusters com diferentes capacidades e configurações. Ele pode ser usado para modelagem e simulação de escalonamento de aplicações para várias classes de sistemas computacionais distribuídos e paralelos, tais como clusters, grades, e redes P2P.

O GridSim provê facilidades para a modelagem e simulações de recursos e conectividades de redes com diferentes capacidades, configurações e domínios. Ele suporta primitivas para composição das aplicações, serviços de informação para descoberta de recursos, interfaces para atribuição de tarefas para os recursos e gerenciamento de suas execuções. Essas características podem ser usadas para simular escalonadores de uma grade para a avaliação de desempenho de um algoritmo de escalonamento (Peixoto, 2009).

\section{Arquitetura do GridSim}

O GridSim adota a arquitetura de multicamadas e modularizada para realizar a gerência dos seus componentes de forma separada, conforme apresentado na Figura 3.3. 

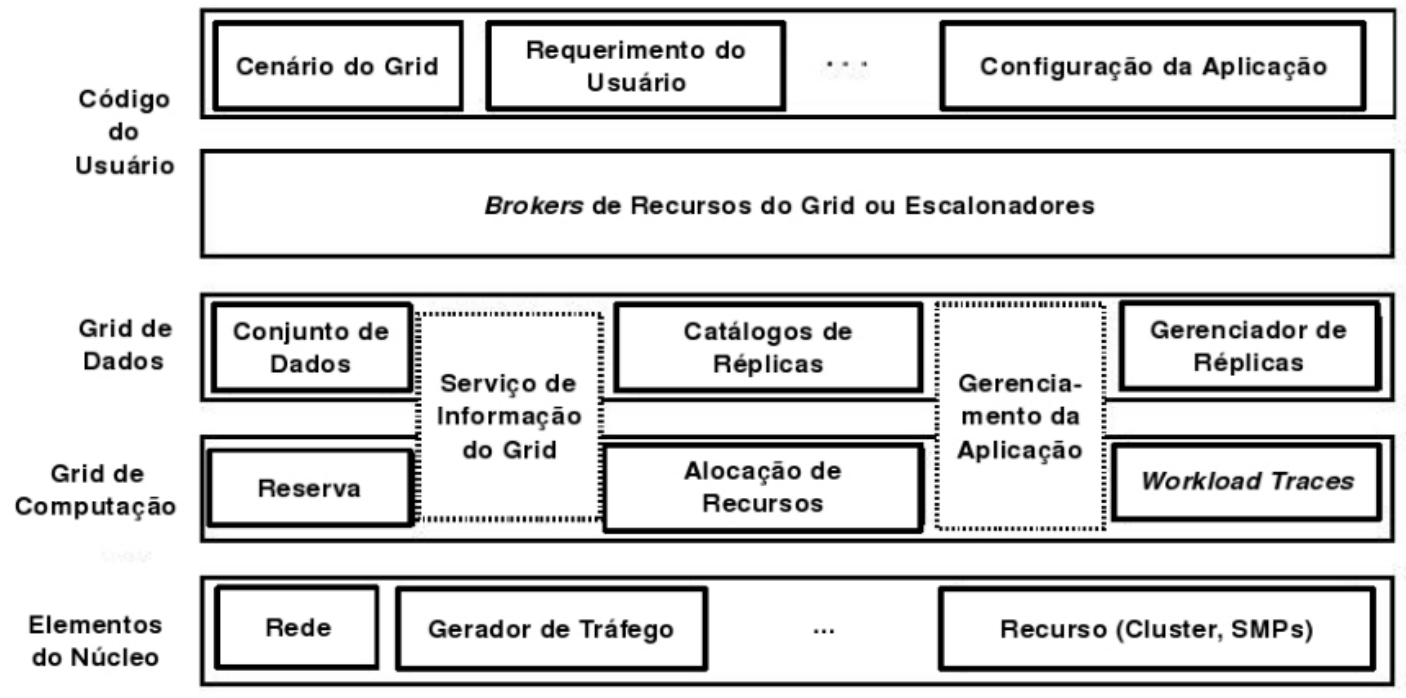

Núcleo de Simulaçāo Sim Java

Figura 3.3: Arquitetura do GridSim 4.1 (Buyya e Murshed, 2002).

A primeira camada está relacionada à Máquina Virtual Java (JVM - Java Virtual Machine), a qual é responsável pela portabilidade entre os ambientes de execução. Ela contém uma infraestrutura de simulação baseada em eventos discretos. Essa infra-estrutura utiliza o SimJava (Kreutzer et al., 1997). A versão 4.1 do GridSim utiliza o SimJava2. O SimJava possui entidades que operam por meio de threads e possui um comportamento que é descrito dentro do método body(), pois o GridSim estende a biblioteca de simulação SimJava que utiliza esse método como padrão para inicialização do ambiente.

A segunda camada descreve a modelagem e a simulação das entidades de uma grade, tais como: os recursos, serviços de informações, modelos de aplicações, interface de acesso. Já as camadas 3 e 4 possuem os elementos do núcleo, e são responsáveis por modelar os elementos da infra-estrutura distribuída, os recursos da grade, tais como cluster, enlaces de rede e repositório de armazenamento. O serviço de informação da grade e o gerenciamento de tarefas são comuns às duas camadas. A quinta camada permite a simulação de recursos agregados chamados Grids brokers ou escalonadores. Por fim, a última camada foca na aplicação e modelagem de recursos com diferentes cenários para avaliar o escalonamento e as políticas de gerenciamento de recursos, heurísticas, e algoritmos. Nessa camada são definidas as configurações do ambiente de simulação e os requisitos impostos pelo usuário, tais como a quantidade e o tamanho das tarefas, a frequiência de criação, os arquivos de E/S, os recursos necessários para execução, largura de banda entre o usuário e os recursos. A configuração dos recursos pode apresentar um conjunto de informações que envolvem a quantidade de processadores para cada máquina, largura de banda, tipo de política implementada (time-shared ou space-shared) e o custo para acesso ao recurso, entre outros. Na versão 4.1 do GridSim também é possível utilizar variações topológicas de rede, reserva avançada 
de recursos e tolerância a falta de recursos (Buyya e Murshed, 2002) (Peixoto, 2009) (GridSim, 2011).

\section{Módulos do GridSim}

Os módulos do GridSim permitem que os usuários realizem as alterações e configurações desejadas nas simulações. O GridSim suporta módulos para execução em um ou múltiplos processadores. Os recursos heterogêneos podem ser configurados como time-shared ou space-shared. Durante a simulação, o GridSim cria um número de módulos multi-threads que rodam em paralelo durante a execução. Alguns desses módulos do ambiente de simulação GridSim são descrit0s a seguir (Buyya e Murshed, 2002) (Peixoto, 2009) (GridSim, 2011):

- Usuário: cada instância de usuário pode se distinguir das restantes com relação às características da tarefa criada, nomeada Gridlet, como por exemplo, tempo de execução e o custo de execução da tarefa.

- Carga de Trabalho: também conhecida como Gridlet, possui alguns elementos que compõem o protocolo de trocas de informações entre as organizações. Um Gridlet possui um elemento length que representa o total de computação desejado por aquele objeto dado em MIPS. O elemento file consiste do tamanho do arquivo a ser transmitido sobre a rede e por fim, o elemento out representa o tamanho do arquivo de retorno com a resposta obtida, ambos dados em Bytes.

- Taxa de chegada das Gridlets: pode ser utilizada uma distribuição estatística para caracterizar a taxa de chegada das Gridlets no sistema.

- GIS (Global Information System): fornece um serviço de registro de recursos e mantém uma lista de recursos disponíveis em uma grade. Os escalonadores podem consultar essa lista para buscar informações sobre os recursos como as configurações existentes e informações do estado atual.

- Escalonador: cada usuário é conectado a uma instância de uma entidade do escalonador. Toda tarefa de um usuário é primeiramente submetida para o seu escalonador e este escalona as tarefas de acordo com a política de escalonamento adotada. Antes de escalonar as tarefas, o escalonador realiza a monitoração dinamicamente de uma lista de recursos disponíveis a partir de uma entidade de diretório global. Todos os escalonadores tentam otimizar as políticas de escalonamento para os seus usuários e, portanto, é esperada uma concorrência para acesso aos recursos. O algoritmo de escalonamento usado pelos escalonadores deve ser adaptável para uma situação de demanda/oferta de mercado.

- Políticas: as políticas de escalonamento atuam sobre as organizações com a função de realizar a distribuição das Gridlets e objetivando atingir os critérios propostos a priori pela comunidade organizacional. 
- Recursos: cada instância de recurso pode vir a apresentar diferentes características como:

Número de processadores.

Custo de processamento.

Velocidade de processamento.

Política de processamento interno (time-shared ou space-shared).

A velocidade do recurso e o tempo de execução de uma tarefa podem ser definidos em termos de taxas padronizadas de benchmarks tais como MIPS e SPEC.

- Entrada e Saída: o fluxo de informações entre as entidades do GridSim acontece através de suas entidades de entrada e saída. Toda entidade do GridSim conectada a rede tem canais ou portas de E/S, os quais são usados para estabelecimento de um link entre as entidades que se comunicam. Note que a entidade do GridSim e sua entidade de E/S utilizam threads, ou seja, cada uma delas têm suas próprias threads de execução com o método body() que lida com os eventos. O uso separado de entidades de comunicação torna possível modelar uma comunicação de nível full-dulplex e multiusuário. O suporte para buffer nos canais de E/S associados com toda entidade do GridSim provê um mecanismo simples para uma entidade se comunicar com outras entidades e ao mesmo tempo possibilitar uma comunicação transparente.

\subsection{Projetos que envolvem Grades Computacionais}

As grades computacionais utilizam recursos disponíveis no maior número de pontos possíveis, espalhados geograficamente ao redor do planeta. Ao contrário dos clusters, as grades se estendem a regiões geograficamente distantes, ficando limitada apenas à disponibilidade do meio de comunicação que atualmente é a Internet. As grades também não precisam trabalhar de forma centralizada, e não precisam ser necessariamente um computador.

Grandes projetos como o WLCG (Worldwide Large Hadron Collider Computing Grid) (LHC, 2005) visam utilizar grades computacionais para distribuir os dados obtidos para vários pontos geográficos. Além de diminuir a carga em seus servidores, esse projeto compartilha cópias de dados em diferentes pontos, o que facilita o acesso à informação para mais de 5000 cientistas distribuídos ao redor do mundo. Projetos como o GPUGRID.net (GPUGRID.net, 2011) vão mais além e buscam recursos computacionais disponíveis no PlayStation $3{ }^{1}$. Nesta Seção são abordados esses dois projetos.

\footnotetext{
${ }^{1}$ PlayStation 3 é uma estação de jogos de última geração desenvolvido pela Sony.
} 


\subsubsection{Projeto WLCG}

O projeto LCG (LHC Computing Grid Project) foi aprovado pelo conselho do CERN (Conseil Européen pour la Recherche Nucléaire - European Organization for Nuclear Research - Organização Européia para a Pesquisa Nuclear) em 20 de setembro de 2001, para desenvolver, construir e manter uma infra-estrutura computacional distribuída. A finalidade desta infra-estrutura é o armazenamento e a análise de dados provenientes de quatro experimentos principais do LHC (Large Hadron Collider) (LHC, 2005). A expansão mundial do LCG fez com que o projeto recebesse o nome Worldwide LHC Computing Grid (WLCG).

O LHC é um potente acelerador de partículas subatômicas criado pelo CERN com o objetivo de tentar recriar o cenário que sucedeu o Bing Bang. Este grande projeto, que entrou realmente em operação em setembro de 2008, demandou esforços de vários cientistas por quase 20 anos com um custo de aproximadamente 10 bilhões de dólares.

Físicos de todo o mundo estão interessados nos resultados para tentar esclarecer a origem do universo. A Figura 3.4 demonstra o LHC. O enorme equipamento é composto por um anel de $27 \mathrm{~km}$ de circunferência localizado entre a Suíça e a França, a 100 metros de profundidade e é equipado com quatro detectores de partículas (LHC, 2009).

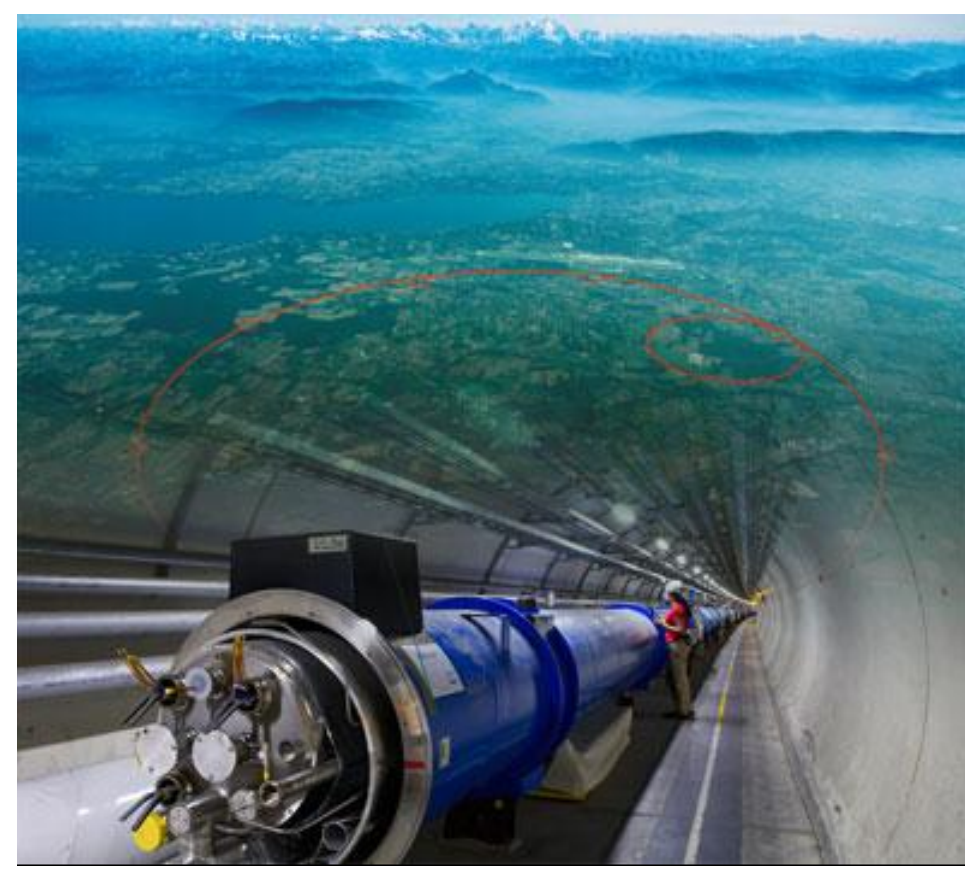

Figura 3.4: Localização e parte do anel do LHC (LHC, 2008).

O WLCG trabalha com mais de 15 milhões de gigabytes (15 pentabytes) de informações anualmente. Tais dados são produzidos por centenas de milhares de colisões subatômicas por segundo que são captados pelos quatro principais detectores de partículas:

- ALICE (A Large Ion Collider Experiment): trata-se de um experimento para detectar colisões de grandes íons e coletar informações das partículas resultantes (Alice, 2006). 
- ATLAS (A Toroidal LHC ApparatuS): experimento de propósito geral, que investiga vários fenômenos físicos (Atlas, 2006).

- CMS (Compact Muon Solenoid): possui o mesmo propósito do ATLAS, analisar fenômenos físicos oriundos das colisões (CMS, 2006).

- LHCb (Large Hadron Collider beauty): investiga as diferenças das matérias e anti-matérias nos momentos das colisões para tentar entender como a matéria sobrepujou a anti-matéria. Para isso ele estuda um tipo de partícula chamada beauty quark ou bquark (LHCb, 2006).

Para armazenar e analisar a enorme quantidade de dados gerada por estes quatro experimentos, o WLCG optou por utilizar grades computacionais. Quando o projeto foi iniciado em 1999, estava claro que seria necessário um sistema computacional de grande porte para analisar os dados gerados pelo LHC, e isto estava além da capacidade financeira disponível pelo CERN. Assim laboratórios e universidades uniram-se, viabilizando a criação de uma grade computacional, onde a maioria dos colaboradores do LHC possui acesso ao centro de pesquisa (LHC, 2005).

Apesar da maioria dos projetos colaborativos em grades chegarem até o usuário doméstico, o projeto WLCG não atinge este escopo, pois o projeto foi criado para manipular grandes quantias de dados gerados pelo LHC e nenhum computador residencial tem recursos ou programas de análises para trabalhar com este tipo de dado (LHC, 2005).

O CERN possui uma infra-estrutura de hardware de referência mundial, onde foram investidos cerca de 100 milhões de euros no projeto WLCG até 2008. Esse investimento foi aplicado em laboratórios de alta tecnologia como os ilustrados na Figura 3.5, com a principal finalidade de processamento e armazenamento de dados coletados dos experimentos do LHC (WLCG, 2006).
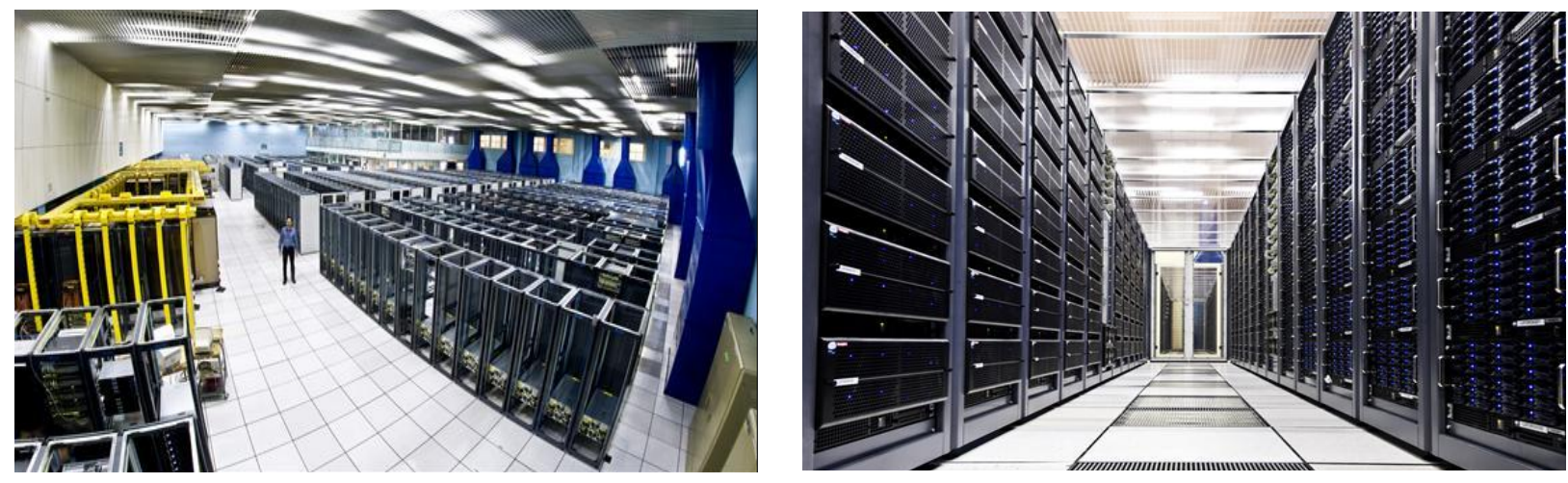

Figura 3.5: Laboratório do CERN para o projeto WLCG (Cern, 2008).

O gerenciamento dos recursos, da conectividade e a interoperabilidade com outras grades computacionais são pontos importantes para o projeto WLCG, contudo são atividades complexas. O middleware é a camada entre toda esta complexidade e as aplicações dos usuários. Esta camada deve facilitar o gerenciamento dos recursos, além de prover segurança e fornecer informações sobre toda a grade de uma forma virtual, criando uma visão ubíqua para o usuário de que todos os recursos estão concentrados e disponíveis em apenas um local. 
O WLCG utiliza um middleware denominado gLite, que tem sido desenvolvido pelo projeto EGEE (Enabling Grids for E-sciencE - Europa), e programas de outros projetos como Globus, European DataGrid, DataTag, GriPhyN, iVDGL (International Virtual Data Grid Laboratory) (Donno, 2006).

Com uma colaboração global que reúne mais de 140 centros de computação científica em 35 países (Castro, 2006), o projeto WLCG apresenta a maior infra-estrutura de grade computacional no mundo. Além dos benefícios para a área da física nuclear, este projeto também envolve vários cientistas de outras áreas, como engenharia e computação. Além disso, ele demonstra que a utilização de grades computacionais tem sido uma boa solução quando os recursos financeiros são limitados e são necessárias uma alta capacidade de processamento e uma grande quantidade de armazenamento de dados. São inúmeras as vantagens que o CERN obteve com a utilização de grades computacionais, dentre as quais pode-se citar:

- Menor custo (em equipamentos e manutenção);

- Estreitamento das relações entre as comunidades científicas ao redor do mundo e compartilhamento de informações, devido ao efeito colaborativo proposto pela grade;

- Distribuição e cópias de dados importantes espalhados geograficamente (backups);

- Utilização de recursos computacionais ociosos ao redor do mundo, aproveitando o consumo energia, matéria prima, entre outros;

- Incentivo a área da computação paralela e distribuída.

\subsubsection{Projeto GPUGRID.net}

O GPUGRID.net, também conhecido por PS3GRID.net, é um projeto de computação distribuída com o objetivo de auxiliar pesquisas na área da biologia molecular. Este projeto utiliza grades computacionais formadas por computadores com placas de vídeo que dispõem de unidade de processamento gráfico (GPU - Graphics Processing Unit) e por consoles de PlayStation 3 (PS3).

As pesquisas que envolvem biologia molecular necessitam de muitas simulações, uma delas denominada Molecular Dynamics (MD). Este tipo de simulação possibilita a modelagem de um vasto sistema molecular em um nível atômico, porém os complexos algoritmos utilizados para este fim acabam por envolver enormes custos de processamento, até mesmo para um sistema HPC (High Performance Computing). Recentes técnicas estatísticas permitiram a criação de um novo protocolo computacional que não necessita de qualquer recurso computacional gerado por métodos anteriores, ou seja, uma simulação muito longa pode ser dividida em várias simulações menores e serem executadas paralelamente, pois uma não depende dos resultados das outras.

Contudo para realizar estas simulações é necessário um sistema HPC dedicado com vários processadores e isto acarreta em um alto custo. O PS3GRID.net propõe a utilização de PlayStations 3 
que utilizam o processador Cell Broadband Engine (Cell BE) capaz de processar dados de forma maciçamente paralela (Harvey et al., 2007)). Com nove processadores internos e um custo de desenvolvimento de 400 milhões de dólares, o Cell BE é um produto gerado do esforço comum entre a IBM, Sony e Toshiba. Seu propósito original foi fornecer uma alta capacidade de processamento de imagens e dados para a terceira geração da estação de jogos da Sony, o PlayStation 3 (Moore, 2006). Porém, devido a sua alta capacidade de processamento paralelo, sua utilização foi ampliada para vários outros estudos, como por exemplo, em sistemas de tempo real (Maeda et al., 2005).

Os processadores Cells $B E$ apresentam resultados de desempenho superiores a outros processadores como o Intel Pentium 4 Xeon e AMD Opteron (Mercury, 2006). A Figura 3.6 demonstra a comparação entre o Cell BE e outros processadores.

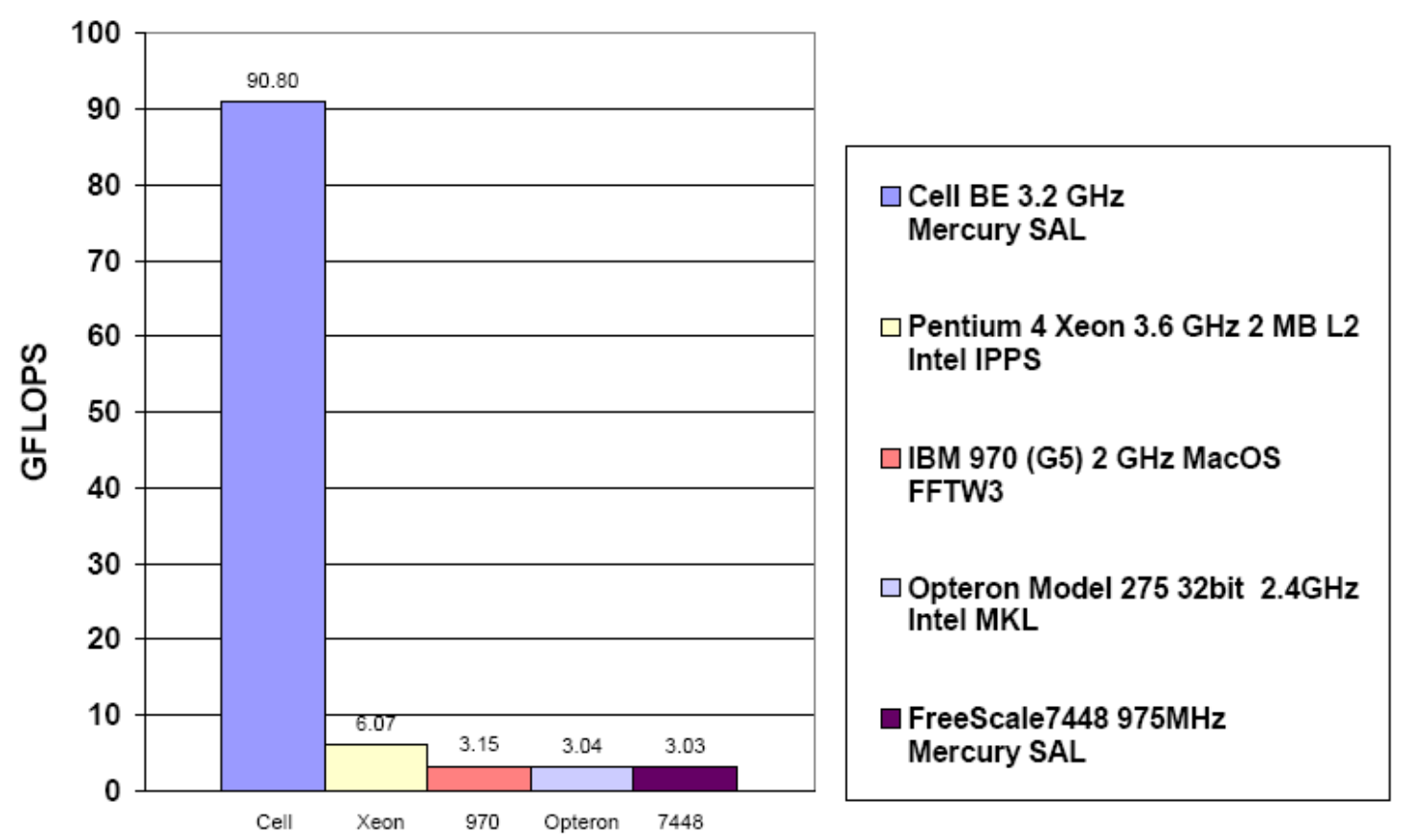

64K Single Precision Complex FFT

Figura 3.6: Comparação de desempenho entre processadores (Mercury, 2006).

A arquitetura do Cell BE é composta por nove processadores sendo um denominado Power Processor Element (PPE), que roda como processador principal, e outros oito processadores independentes especializados, processando elementos sinergeticamente (Synergistic Processing Elements - SPEs) (Harvey et al., 2007). O PPE e os SPEs são altamente integrados. O PPE prove funções de controle comuns, executa o sistema operacional, e controla a aplicação, enquanto que o SPE prove o desempenho para várias aplicações. O PPE e os SPES compartilham o endereço de tradução e a arquitetura da memória virtual, provendo suporte para virtualização e particionamento de sistemas dinâmicos. Eles também compartilham as tabelas de páginas do sistema e as outras funções como a apresentação de interrupções. Finalmente eles compartilham formatos de 
tipos de dados e operações de semântica para possibilitar o compartilhamento de dados entre eles (Gschwind et al., 2006).

Os pesquisados notaram que a grande capacidade de processamento paralelo do Cell $B E$ auxilia nos projetos envolvendo biologia molecular. Porém, um único console de PlayStation 3 não é suficiente para realizar as várias simulações MD. Assim, foram criados clusters compostos por diversos consoles de PlayStation 3 que fornecem recursos computacionais como interface de rede, memória e disco rígido.

Projetos em universidades, como o projeto Folding@Home (Folding, 2006), da Universidade de Stanford, que visa descobrir o processo de formação e a cura de doenças como o mal de Alzheimer e o da professora Mônica Pickholz na Universidade Estadual de Campinas (Unicamp) (FAPESP, 2007) (ESTADAO, 2007), de cálculos de bioinformática, são exemplos da utilização de PlayStations 3 para pesquisas de dinâmica molecular. Ambos os projetos envolveram a criação de clusters com consoles interligados e apresentam resultados positivos.

Apesar dos consoles PlayStations 3 serem mais eficientes que alguns computadores convencionais para este determinado tipo de processamento, seu custo ainda é elevado além do desperdício de recursos como o joystick e o leitor Blu-ray que ficam inutilizados.

Mesmo com a criação de clusters, as pesquisas de biologia molecular ainda necessitavam de maior capacidade computacional para as simulações. As grades computacionais colaborativas são uma solução amplamente utilizada por vários projetos científicos ao redor do planeta. Elas também foram adotadas pelas pesquisas biológicas e especificamente para a biologia molecular.

O PS3 atualizado com a última versão de firmware é capaz de iniciar (boot) outros sistemas operacionais a partir de sua interface USB (Universal Serial Bus). No caso do GPUGRID.net é recomendado instalar o Yellow Dog Linux, e após a instalação o usuário deve instalar o BOINC (Berkeley Open Infrastructure for Network Computing), que é um middleware desenvolvido pela universidade de Berkeley para grades computacionais distribuídas.

Além de receber dados dos PS3, o GPUGRID.net também recebe dados processados por placas de vídeos da NVIDIA. Neste caso o usuário que deseja colaborar com a grade, deve apenas instalar o middleware BOINC. Este aplicativo possui versões para Windows 32 e 64bits e também para Linux (GPUGRID.net, 2011).

As interfaces gráficas modernas são dotadas de GPU que contém centenas de unidades aritméticas, podendo ser utilizadas para prover acelerações de aplicações científicas. O aumento da flexibilidade da mais recente geração de hardware GPU combinado com linguagens de programação GPU de alto nível e plataformas como CUDA (Complete Unified Device Architecture), facilitou a utilização desse poder computacional que ficou mais acessível aos cientistas (GPU, 2011).

As recentes placas de vídeos com GPU da NVIDIA suportam a arquitetura NVIDIA CUDA. CUDA é uma plataforma de software para computação maciçamente paralela de alto desempenho (Halfhill, 2008). 
Com um preço mais acessível, um alto poder de processamento paralelo e facilidade de programação para desenvolvimento de aplicações, as placas com GPU se destacam como opção de processamento paralelo. Projetos científicos estão utilizando computadores com várias placas de vídeos integradas criando assim, supercomputadores em uma única máquina. Outra vantagem da utilização de GPUs é que as interfaces de vídeo podem ser instaladas em computadores convencionais, diferentemente das grades formadas por PS3.

Tanto o PlayStation 3 como as placas de vídeo com tecnologia GPU são aproveitados pelo middleware BOINC. Inicialmente criado para o projeto SETI@HOME (SETI@HOME, 2011), que utiliza uma grade computacional para busca de sinais de vida extraterrestre, o BOINC possui uma plataforma de software para prover uma infra-estrutura computacional distribuída entre o cliente colaborador e o servidor que envia os dados a serem processados ou armazenados e recebe os resultados. Atualmente o BOINC é utilizado por vários outros projetos que participam de grades filantrópicas, inclusive o GPUGRID.net.

O projeto GPUGRID.net demonstra o avanço das grades computacionais em busca de recursos e processamento em equipamentos diferentes dos tradicionais. Há servidores e clusters com processadores Cell BE e com GPUs que são comercializados, contudo, o custo é alto. No entanto, as pesquisas científicas realizadas com grades filantrópicas têm mostrado alguns bons resultados.

\subsection{Considerações Finais}

As Grades Computacionais são uma solução interessante para aplicações distribuídas, pois além de oferecer um baixo custo, já que os clientes são usuários voluntários (computação filantrópica), permitem um grande aumento no poder de processamento dos dados e aplicações, principalmente àquelas relacionadas a pesquisas científicas.

Em tempos em que existe uma grande preocupação com o meio ambiente, o uso de grades computacionais torna-se interessante devido a aspectos como a economia de energia e a redução da utilização de matérias primas. Por exemplo, considerando duas instituições, uma localizada no Brasil e outra no Japão, com 50 computadores cada. Havendo a necessidade de um aumento da capacidade de processamento de 50 computadores em cada entidade, e não considerando que exista uma grade computacional, seria necessária a compra de 100 equipamentos, conseqüentemente gerando aumento nos gastos financeiros, maior consumo de energia e maior utilização de matéria prima. Utilizando grades computacionais e levando-se em consideração o fuso horário, a sede brasileira poderia utilizar os recursos computacionais ociosos localizados na sede japonesa e viceversa. Com isso não seria necessária a aquisição de mais computadores, levando a um menor consumo de matérias primas e uma redução no consumo de energia.

A tecnologia de grades computacionais vem conquistando cada vez mais espaço em várias pesquisas científicas de diversas áreas, com contribuições de vários usuários ao redor do mundo 
que disponibilizam seus equipamentos para auxiliar em projetos como a busca pelo tratamento de câncer, busca de vida inteligente fora do planeta, origem da criação do universo, entre outros.

Outro aspecto atual envolvendo grades computacionais é a sua expansão para diferentes tipos de equipamentos que não precisam ser necessariamente um computador convencional como, por exemplo, a utilização de consolers de vídeo-game e placas aceleradoras de vídeo. Assim, no cenário atual da televisão brasileira, onde é realizada a transição do Sistema de Televisão Analógica para o Digital, pode-se criar uma grade computacional que utiliza os recursos ociosos dos receptores digitais para prover uma alta capacidade de processamento conforme propõe o middleware Grid Anywhere. 


\section{CAPÍTULO \\ 4}

Grid Anywhere

\subsection{Considerações Iniciais}

O Grid Anywhere é um middleware que permite a construção de uma grade computacional ponto-a-ponto (P2P) utilizando qualquer equipamento dotado de recursos computacionais, como computadores, PDAs (Personal Digital Assistant), celulares, receptores digitais, entre outros (Teixeira, 2009) (Teixeira et al., 2010).

Ele permite que o compartilhamento seja realizado de maneira bidirecional, onde o receptor digital pode atuar nos papéis de provedor e consumidor de recursos. Uma vez no papel de provedor, o receptor pode compartilhar seus ciclos ociosos de unidade de processamento (CPU) para que usuários remotos possam utilizá-los para fins de diversas naturezas. No papel de consumidor, o receptor pode fazer uso de recursos remotos de maneira a aumentar a potência computacional disponibilizada para a execução de aplicativos (Teixeira, 2009) (Teixeira et al., 2010).

Uma vez adotada a arquitetura P2P na construção da grade computacional, toma-se como prérequisito a existência, no receptor, de um canal de retorno capaz de prover acesso à Internet, o que possibilita a troca de informações (requisição e/ou envio) entre o telespectador e a emissora (Neves, 2010) (Santos Jr et al., 2010). Esse canal de retorno permite ainda que um receptor se comunique diretamente com outros equipamentos da mesma natureza ou computadores convencionais. A Figura 4.1 ilustra a arquitetura da grade computacional do middleware Grid Anywhere. Essa arquitetura conta com os seguintes componentes:

- PC Peer: computador pessoal convencional que é conectado à grade por meio da Internet. Pode atuar nos papéis de provedor e consumidor de recursos; 
- Broadcaster Peer: participante localizado na emissora de TV. Pode prover uma grande potência computacional de processamento, visto que ele envia, via broadcast, aplicações para que sejam executadas em todos os receptores sintonizados em seu canal;

- TV Peer: receptor digital ou aparelho televisor com receptor compatível integrado. Possui todas as características do PC Peer adicionadas à capacidade de receber uma aplicação enviada pela emissora de TV via broadcast.

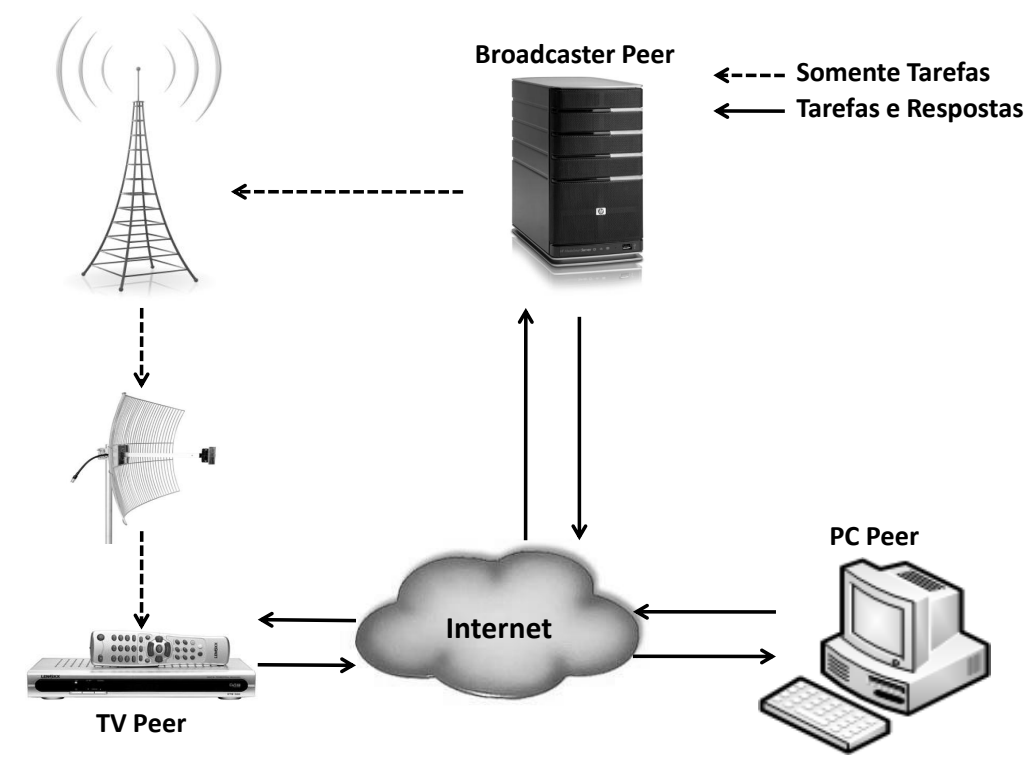

Figura 4.1: Ambiente Grid Anywhere (Teixeira, 2009) (Teixeira et al., 2010).

$\mathrm{Na}$ arquitetura apresentada pela Figura 4.1, quando a requisição de serviço de um usuário pode ser atendida por meio do uso de um único recurso remoto compartilhado, acessa-se diretamente esse participante (TV Peer ou PC Peer). No entanto, em uma situação que necessite de grande processamento é preciso requisitar o Broadcaster Peer, pois esse participante pode apresentar uma grande potência computacional, uma vez que pode utilizar os receptores sintonizados à emissora de TV onde ele está localizado (Teixeira et al., 2010).

O middleware Grid Anywhere oferece ao programador um ambiente para construir aplicações de uma grade de forma transparente. É baseado na migração de objetos Java e na invocação de métodos remotos, um modelo de programação onde o programador define as classes que podem ser acessadas remotamente. O middleware usa instrumentação de código e gerencia automaticamente a migração e a invocação de métodos remotos. Assim, o usuário não precisa se preocupar com os detalhes do processo (Teixeira, 2009). 


\subsection{Arquitetura do Middleware Grid Anywhere}

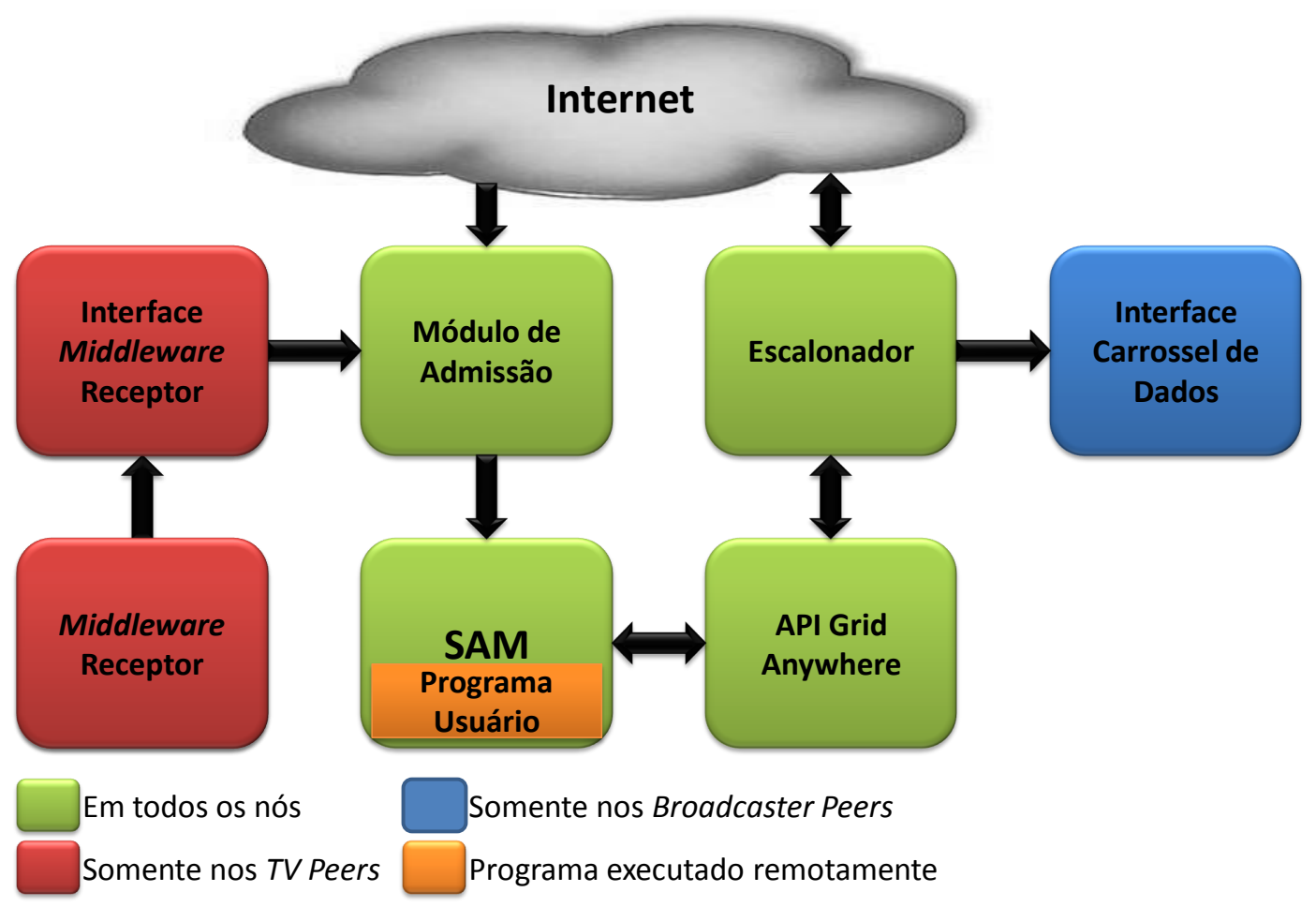

Figura 4.2: Arquitetura do Middleware Grid Anywhere (Teixeira et al., 2010).

$\mathrm{Na}$ Figura 4.2, o Escalonador, quando requisitado, analisa a grade computacional para encontrar o melhor recurso para enviar um objeto serializado para ser hospedado e executado, obedecendo a política de escalonamento adotada. O middleware Grid Anywhere possui uma API (API Grid Anywhere) que pode ser invocada pelo Escalonador ou pelo Sam Dog para obter informações avançadas sobre a grade computacional e tomar decisões.

Sempre que um usuário deseja executar alguma aplicação na grade ele precisa definir se essa aplicação requisita uma máquina simples (para que ele seja enviado para um PC Peer ou para um TV Peer em modo unicast) ou uma máquina de alto desempenho. O segundo caso é indicado quando há um grande conjunto de dados que devem ser processados. Assim, o objeto que implementa essa aplicação pode ser enviado para um Broadcaster Peer que envia esse objeto para cada equipamento ligado a ele. O Broadcaster Peer usa a Interface do Carrossel de Dados para transmitir o objeto Java da aplicação através da multiplexação de dados com áudio e vídeo, para os recursos.

Quando o provedor de recursos é um TV Peer, a recepção de objetos Java enviados por radiodifusão é feita pelo middleware do Receptor Digital. Assim, há um Módulo de Interface no Middleware do Receptor Digital que é responsável por obter o objeto recebido e enviá-lo para o Módulo de Admissão. 
O Módulo de Admissão é utilizado quando o equipamento tem o papel de provedor de recursos. Ele negocia a execução com o Escalonador e recebe um objeto Java para ser instalado. Uma vez que o objeto Java é instalado, ele é executado no módulo Sam Dog. Esse módulo é responsável por executar os aplicativos de forma segura.

O programa Java executado pode utilizar interfaces de comunicação convencionais (como sockets) ou a API do Middleware para obter os dados a serem processados. Terminada a execução, os resultados são enviados de volta ao usuário de origem.

\subsection{Segurança}

A segurança é uma questão muito importante no ambiente de grade do Grid Anywhere. Os recursos executam aplicações na maioria das vezes desenvolvidas por programadores desconhecidos. Assim, a execução do programa em um modo inseguro pode ser perigosa para o sistema local. $\mathrm{O}$ Sam Dog é um sistema de segurança responsável por executar uma aplicação Java de forma segura e gerenciar o controle de acesso de qualquer sistema computacional (Teixeira et al., 2010). Sua principal função é permitir que o usuário defina suas regras de segurança de forma simples.

O Sam Dog é composto por um componente chamado Domain Security Manager (DSM) que é responsável por determinar e providenciar uma lista de controle de acesso para um domínio de aplicação. Um domínio de aplicação pode ser criado para gerenciar uma instituição participante da grade computacional.

Os domínios são organizados em uma estrutura hierárquica, onde cada domínio é ligado a um domínio superior e a outros subdomínios. Cada domínio possui um administrador independente e uma política de segurança exclusiva que é herdada pelos subdomínios. Assim, quando as regras são processadas, o sistema processa primeiramente as regras definidas no domínio local e, caso nenhuma regra for encontrada, as regras definidas no domínio superior são processadas. Isso é feito em ordem inversa da hierarquia, do nível mais baixo para o mais alto, caracterizando uma abordagem de lista de controle de acesso em cascata (Teixeira et al., 2011).

\subsection{Migração de objeto}

Com o objetivo de aumentar a capacidade de processamento e diminuir o tempo de resposta (quando uma aplicação interativa é usada), o middleware Grid Anywhere utiliza a migração de objetos Java. Toda vez que um recurso da grade precisa de mais potência computacional para executar sua aplicação, alguns objetos são serializados e enviados para outro recurso (que reconstrói o objeto). Um documento XML é usado para descrever a invocação do método (nome do método e os valores dos parâmetros). Quando a execução é feita três ações são possíveis: a) o valor retornado do método é enviado para o recurso de origem; b) se um método void é chamado, o objeto ainda continua na máquina de destino com uma possível mudança de estado, c) o objeto é seriali- 
zado e volta novamente para o recurso de origem. A Figura 4.3 mostra um diagrama de seqüência que apresenta o padrão de troca de mensagens do Grid Anywhere.

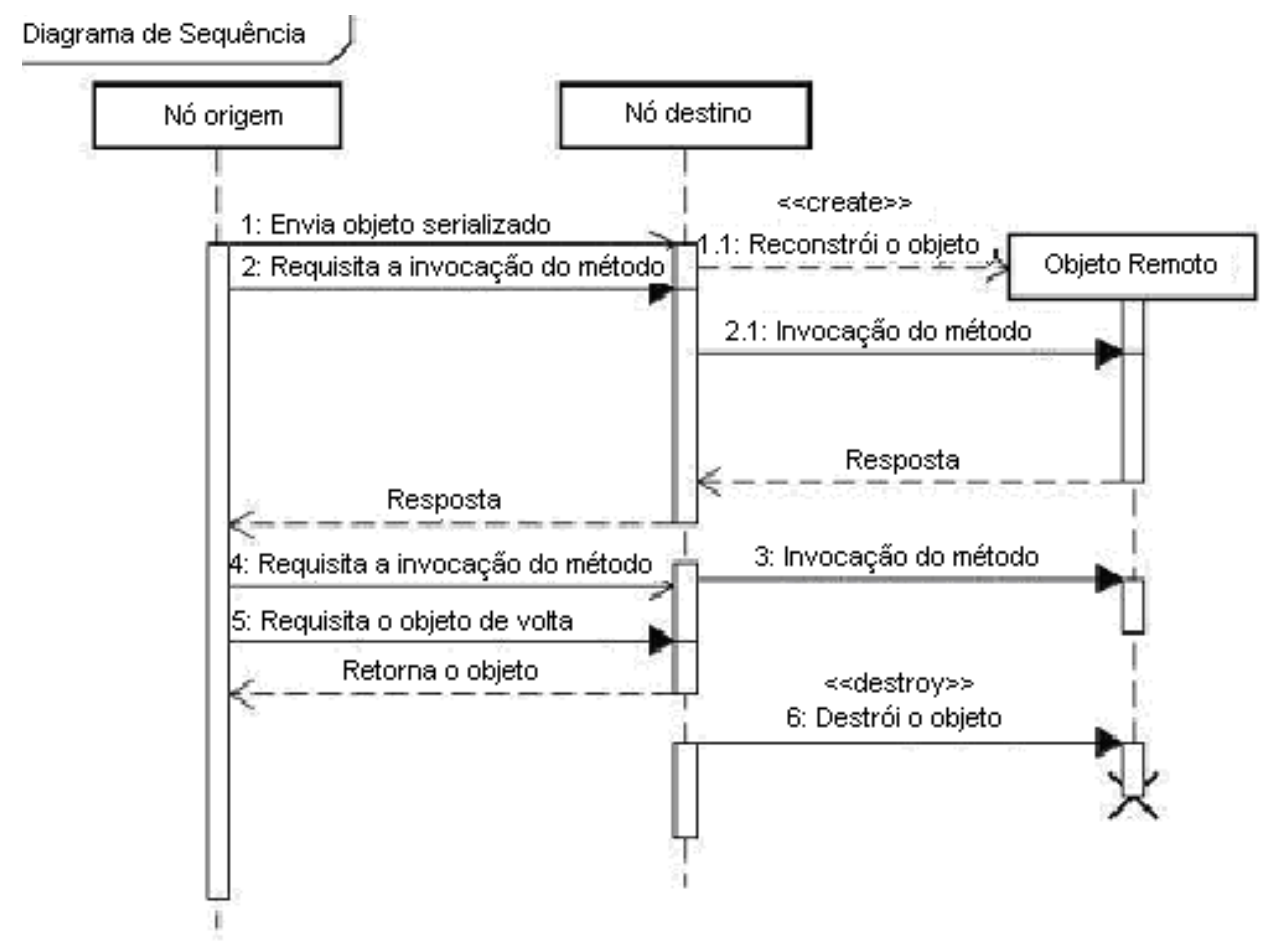

Figura 4.3: Padrão de troca de mensagens no Grid Anywhere (Teixeira et al., 2010).

A sequiência 1 apresenta uma chamada síncrona. O objeto serializado é enviado e reconstruído no recurso de destino. Em seguida é feita a invocação do método remoto e a resposta é retornada de volta ao recurso de origem. Na seqüência 4 é realizada uma invocação assíncrona onde não há resposta. Por fim a seqüência 5 apresenta um processo para pedir o objeto de volta.

Para fazer o objeto de transferência o middleware utiliza Sockets Java. É importante considerar o tamanho do objeto antes da migração por causa da sobrecarga de transferência. O escalonador pode fazer uma previsão do tempo que será gasto para migrar um objeto e tomar a decisão de mover o objeto (e decidir o recurso de destino) ou mantê-lo localmente.

\subsection{Considerações Finais}

Para que uma grade computacional possa ser utilizada em larga escala é importante que seja ofertado um grande número de recursos e exista um middleware que seja de simples instalação e manipulação por usuários com menos experiência técnica. Para isso, este Capítulo apresentou o middleware Grid Anywhere, que permite a construção de uma grade computacional utilizando recursos ociosos de qualquer equipamento dotado de recursos computacionais como computadores convencionais, celulares e receptores de sinais digitais de TV. O próximo Capítulo apresenta as 
etapas de desenvolvimento deste projeto de mestrado que simula uma grade computacional composta por receptores digitais e computadores convencionais aplicando os conceitos definidos pelo Grid Anywhere. 


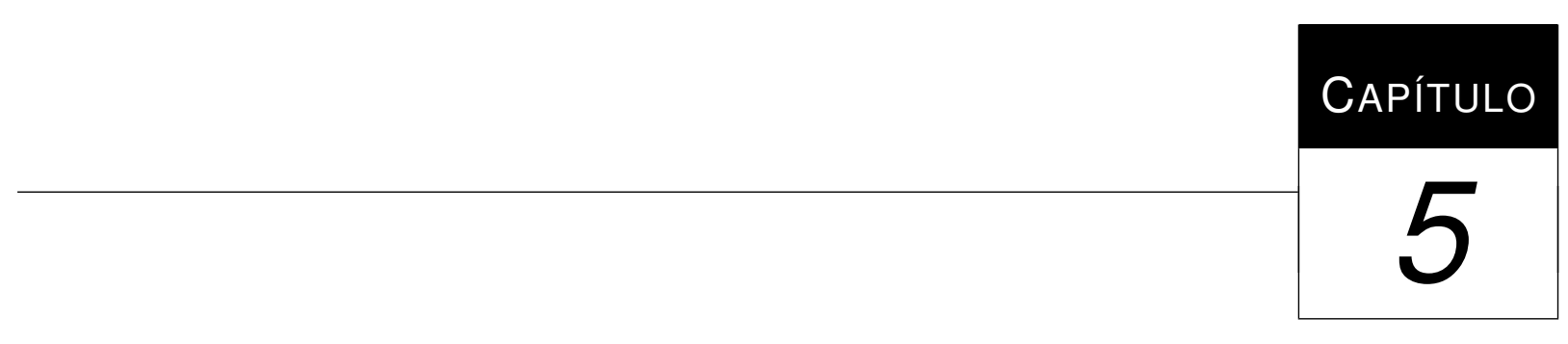

\section{Desenvolvimento do Projeto}

\subsection{Considerações Iniciais}

Conforme afirmado por Zuffo (Zuffo, 2006), o Brasil em 2006 contava com aproximadamente 54 milhões de aparelhos televisores. De acordo com o Instituto Brasileiro de Geografia e Estatística (IBGE), em 2008, 95,1\% dos domicílios brasileiros possuíam televisão (G1, 2008). Com a implantação do Sistema de Televisão Digital é necessário que os telespectadores adquiram receptores digitais, os quais podem atingir um número aproximado de 80 milhões de unidades em um período inferior a dez anos (Batista et al., 2007). Para que este equipamento seja capaz de realizar as funções de decodificação de sinal, reprodução de áudio e vídeo, execução de aplicações, entre outras funcionalidades, é preciso que ele seja equipado com recursos computacionais convencionais como, por exemplo, unidade de processamento e memória (Fernandes et al., 2004).

Tendo em vista o grande número de receptores que, potencialmente, o país pode possuir dentro de alguns anos e a natureza computacional do receptor digital, é grande o número de recursos computacionais desses equipamentos que poderão estar ociosos, tornando interessante aproveitálos de uma maneira colaborativa, como em uma grade computacional (Teixeira, 2009) (Teixeira et al., 2010).

Vale lembrar que, em um ambiente de Televisão Digital Interativa, é possível que a emissora envie uma aplicação para ser executada no receptor do telespectador e o resultado pode ser enviado de volta via IP, desde que exista um canal de retorno com acesso a Internet. Com isso, para essa distribuição das aplicações é necessário que o mecanismo de escalonamento seja robusto e eficaz.

Nas emissoras de televisão, o momento é de análise dos testes feitos ao longo dos últimos anos e de estudo sobre as melhores formas de oferecer a interatividade. Esses estudos incluem a 
definição de modelos de negócio, ou seja, como comercializar as aplicações interativas. Existem muitos modelos, nenhum amplamente aceito, pois o Sistema de TV Digital Interativa que está em implantação no país ainda começa a dar os seus primeiros passos.

Com a digitalização da programação das emissoras de TV surgem outros recursos que podem ser explorados comercialmente. Além de vender espaços dentro da programação, é possível comercializar parte da taxa de transmissão da interatividade. Na TV Digital a emissora define a taxa de transmissão das aplicações através do carrossel de dados, que permite que as aplicações sejam transmitidas ciclicamente. É possível, por exemplo, transmitir serviços de comércio eletrônico, de acesso a conta bancária, e-mail, loterias, jogos, serviços de saúde, como marcação de consultas, além de aplicações onde o conteúdo é destinado a aprendizagem à distância. Ou seja, uma empresa pode comprar uma parte do carrossel e oferecer qualquer tipo de aplicação.

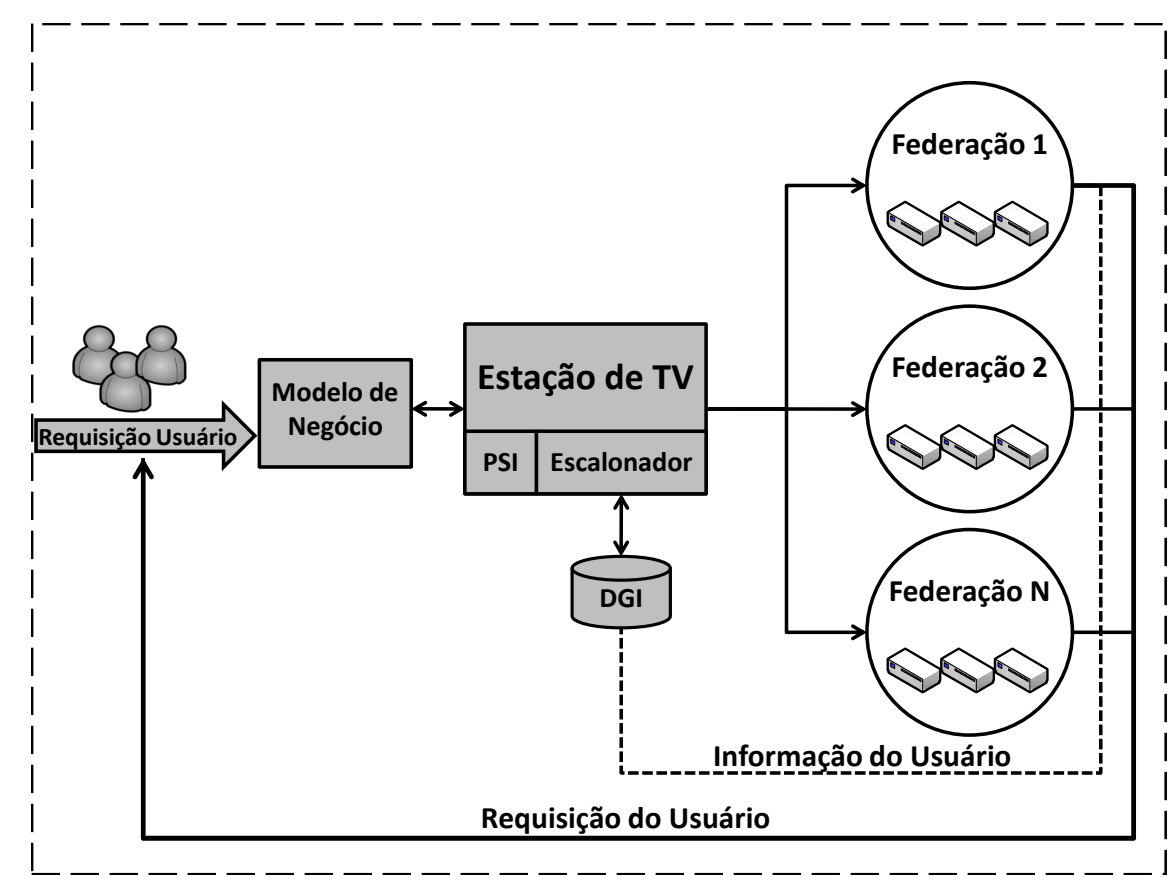

Figura 5.1: Distribuição das Aplicações para as Federações.

A Figura 5.1 apresenta o caminho seguido pelas requisições dos usuários desde a negociação descrita nos parágrafos anteriores até a sua execução em uma das Federações.

Após a negociação entre os usuários e a emissora, a aplicação é submetida ao Provedor de Serviços Interativos (PSI). Após passarem pelo PSI, as aplicações são encaminhadas ao escalonador. Ele é responsável por enviá-las para serem executadas de acordo com a logística da política adotada. Ele pode pode acessar de forma dinâmica o DGI (Diretório Global de Informações) sempre que a política utilizada necessitar de informações sobre os receptores.

As aplicações são programas desenvolvidos em linguagens declarativas e procedurais que, executadas em um receptor digital, oferecem serviços específicos aos telespectadores. Elas podem ser residentes no receptor ou serem transmitidas através do carrossel de dados. 
O objetivo deste projeto de mestrado é avaliar como poderão ser distribuídas as aplicações interativas para os elementos que compõem o ambiente definido pelo Grid Anywhere. Em particular, este trabalho visa avaliar como os receptores digitais para televisão podem ser utilizados para a implementação de uma grade computacional e, por meio dessa grade, possibilitar que um maior número de pessoas se beneficie com os recursos que a televisão digital pode oferecer. Para atingir o objetivo deste projeto, é necessário realizar um experimento que possibilite a obtenção de resultados para avaliar a grade computacional proposta. A metodologia utilizada no experimento citado é descrita na próxima Seção.

\subsection{Metodologia de Trabalho}

Para a realização do experimento descrito na Seção anterior, deve-se inicialmente determinar qual a melhor técnica para coleta de resultados. Em seguida, deve-se verificar como obter informações sobre as aplicações que serão executadas e sobre os tipos de recursos disponíveis para execução dessas aplicações. Esta Seção apresenta as justificativas para utilização de simulação e a metodologia a ser aplicada para a realização do experimento. Na próxima Seção é descrito um estudo sobre os tipos de receptores digitais disponíveis comercialmente e sobre as aplicações interativas existentes uma vez que informações sobre as aplicações que serão executadas e sobre os tipos de recursos disponíveis são essenciais para avaliar a melhor forma de distribuição das aplicações.

Segundo Santana (Santana, 1990a) (Santana, 1990b), podem ser utilizadas duas técnicas para avaliação de desempenho de um sistema: as Técnicas de Aferição e as Técnicas de Modelagem.

Técnicas de Aferição são aplicadas principalmente na avaliação de sistemas já existentes ou em fase final de desenvolvimento (Santana et al., 1997). No caso da aferição de um sistema, pode-se utilizar protótipos, benchmarks ou monitores de hardware ou software (Jain, 1991) (Hofmann et al., 1994). Contudo há uma grande preocupação em não se alterar o funcionamento natural do sistema durante a aferição.

Já o uso da modelagem se mostra bastante atrativo quando os objetos de estudo são sistemas complexos, inexistentes ou que não estejam disponíveis para a experimentação (Jain, 1991). A solução de um modelo pode ser feita utilizando-se tanto um ferramental matemático, levando a uma solução analítica, ou a utilização de um programa de simulação que represente o modelo adequadamente e forneça os dados para a avaliação do desempenho (Kobayashi, 1978) (MacDougall, 1987).

As soluções analíticas são atrativas, principalmente considerando que, quando disponíveis, permitem a avaliação e a inferência de diversos resultados com um esforço computacional muito pequeno. Por outro lado, nem sempre as soluções analíticas são adequadas, uma vez que essas soluções podem ser altamente complexas, levando à necessidade de simplificações sucessivas no 
modelo do sistema, o que pode levar a resultados sem grandes aplicações práticas (MacDougall, 1987) (Soares, 1992).

No uso de simulação, tem-se uma possibilidade de solução dos modelos altamente flexível, uma vez que elaborado um programa de simulação que represente corretamente o modelo, podem ser testadas diversas possibilidades de parametrização do sistema, com resultados computados automaticamente pelo programa de simulação (MacDougall, 1987). Por meio da simulação, podese predizer o comportamento futuro de um projeto ou mesmo de algumas alterações em um sistema existente (Bagrodia et al., 1998).

O processo de desenvolvimento de uma simulação envolve diversas etapas. Primeiro é necessário especificar o modelo, abstraindo as características mais importantes do sistema. A partir do modelo é preciso transformá-lo em um programa de simulação.

Simular é o processo de desenvolver um modelo matemático ou lógico de um sistema real e então realizar experimentos de modo a prever o comportamento real do sistema (Meng, 1999).

O experimento a ser realizado neste trabalho visa avaliar uma grade computacional onde os recursos a serem utilizados são os receptores digitais de televisão. Para a avaliação desse sistema por aferição, seria necessário o desenvolvimento de um protótipo onde seriam implementadas grades compostas de receptores digitais. O desenvolvimento desse protótipo seria bastante dispendioso e a flexibilidade obtida não atenderia a todas possibilidades de projeto que se pretende testar. Desta forma, optou-se pela utilização de simulação baseada em simuladores de grades computacionais disponíveis na literatura e que foram apresentados na Seção 3.6 desta dissertação. A Seção 3.6 apresenta ainda o que motivou a escolha do simulador GridSim.

Para que o experimento seja realizado, algumas etapas foram consideradas, tais etapas são descritas a seguir:

- Definição do modelo a ser utilizado para a simulação da grade computacional: nessa etapa os receptores digitais foram caracterizados. O estudo realizado para definir as características dos recursos da grade a ser simulada é apresentado na Seção 5.3.1.

- Definição da carga de trabalho a ser considerada: a carga de trabalho neste experimento será definida pela execução das aplicações interativas. Desta forma, foi realizado um estudo sobre como essas aplicações se comportam. Esse estudo é apresentado na Seção 5.3.2.

- Definição das políticas de escalonamento: o objetivo deste trabalho é mostrar como as diferentes políticas de escalonamento interferem no desempenho do sistema. As políticas a serem consideradas são apresentadas na Seção 5.3.3.

- Planejamento do experimento: nesta fase são tomadas decisões com relação ao tamanho da simulação, o número de replicações e a maneira como a simulação é inicializada, de modo a manter um custo mínimo, quais os fatores e níveis que serão considerados. As Seções 5.4 e 6.2 apresentam os planejamentos dos experimentos realizados. 
- Análise a apresentação dos resultados: Os métodos para análise de resultados baseiamse em estimar o intervalo de confiança dos valores médios. O Capítulo Seis apresenta os resultados obtidos.

\subsection{Modelagem dos Experimentos}

Conforme descrito anteriormente, o simulador GridSim (Buyya e Murshed, 2002) (GridSim, 2011) foi escolhido para a execução dos experimentos utilizando as características propostas pelo Grid Anywhere. Esse simulador permite a modelagem e simulação de sistemas computacionais distribuídos, aplicações, recursos, além de escalonadores para o projeto e validação de algoritmos de escalonamento.

Foram realizados estudos sobre os tipos de equipamentos disponíveis no mercado como os Receptores Digitais e Media Centers, além das aplicações existentes no Sistema de Televisão Digital. Os resultados destes estudos permitiram a modelagem do ambiente definido pelo Grid Anywhere, onde foram realizadas simulações com dois objetivos distintos: o primeiro foi verificar a sobrecarga imposta por uma determinada aplicação sobre os equipamentos estudados; o segundo foi implementar e analisar três políticas de escalonamento, das quais duas foram propostas neste trabalho.

\subsubsection{Classificação dos Receptores Digitais}

Nesta Seção é apresentada uma classificação dos equipamentos encontrados no mercado que permitem a recepção do sinal digital de televisão. Diversos equipamentos foram analisados com as mais variadas configurações de hardware e software. A Tabela 5.1 apresenta algumas informações sobre alguns dos equipamentos analisados.

Foram analisados vinte e um equipamentos disponíveis no mercado com diferentes características. Observa-se na Tabela 5.1 que os equipamentos com a funcionalidade de receber o sinal digital apresentam uma grande diversidade de recursos tanto em termos de memória como de processador.

Em termos de memória tem-se uma variação que vai de 16 MB a 4 GB. Analisando os processadores, tem-se desde equipamentos com uma potência computacional menor e com frequência de clock de $166 \mathrm{MHz}$ a equipamentos que possuem uma potência computacional igual ou superior a muitos computadores considerados modernos, como por exemplo, o processador Intel Core i7 950 com frequência de clock de $3.07 \mathrm{GHz}$. Percebe-se que a evolução computacional é tão grande que, há alguns anos, os computadores considerados modernos possuíam configurações semelhantes as apresentadas nos equipamentos com potência computacional inferior da Tabela 5.1. Esses equipamentos são específicos pois possuem funcionalidades restritas além da capacidade de receber o sinal digital. Existem também os equipamentos de propósito geral, que possuem funcionalidades equivalentes a de um computador moderno. No entanto, essa superioridade em termos de recursos computacionais é refletida nos preços dos equipamentos. 
Tabela 5.1: Especificações dos Equipamentos Analisados.

\begin{tabular}{|l|l|c|}
\hline \multicolumn{1}{|c|}{ Equipamento } & \multicolumn{1}{c|}{ Processador } & Memória \\
\hline Niveus Pro Series & Intel Core i7 950 3.07GHz & $4 \mathrm{~GB}$ \\
\hline Media Center Idea 3900 & Intel Core 2 Quad Q9650 3.0GHz & $4 \mathrm{~GB}$ \\
\hline Niveus Media Denali & Intel Core 2 Duo E8600 3.3GHz & $4 \mathrm{~GB}$ \\
\hline Megahome MWX & Intel Core 2 Duo E8400 3.0GHz & $4 \mathrm{~GB}$ \\
\hline Munddo & Intel Core 2 Duo T9800 2.93GHz & $4 \mathrm{~GB}$ \\
\hline Vida Box Slim & AMD Athlon 64 X2 6000+ 2.0GHz & $2 \mathrm{~GB}$ \\
\hline Daten Home PC Slim & AMD Athlon 64 X2 4200+2.2GHz & $2 \mathrm{~GB}$ \\
\hline Daten Home PC & AMD Athlon 64 X2 3800+2.0GHz & $2 \mathrm{~GB}$ \\
\hline Replay Plus Viewvox 1000 & AMD Athlon 64 3500+2.2GHz & $2 \mathrm{~GB}$ \\
\hline Inteset Denzel & Intel Pentium 4 3.2GHz & $1 \mathrm{~GB}$ \\
\hline Philips Showline & Intel Pentium 4 3.0GHz & $512 \mathrm{MB}$ \\
\hline Samsung RNG-150 & Broadcom 1122 400MHz & $512 \mathrm{MB}$ \\
\hline Zinwel ZBT 601 & Broadcom 7402 300MHz & $128 \mathrm{MB}$ \\
\hline VisionTec VT7000 & STI 7100 300MHz & $128 \mathrm{MB}$ \\
\hline DigiTV HD & Sti 7100 ST40 266MHz & $128 \mathrm{MB}$ \\
\hline Audio Vision HD031i & SH-3 266MHz & $256 \mathrm{MB}$ \\
\hline Samsung SMT-H1501 & Zoran ZR391055 250MHz & $160 \mathrm{MB}$ \\
\hline Samsung SMT-H3050 & Conexant CX2417X 250MHz & $128 \mathrm{MB}$ \\
\hline Samsung SMT-2110C & NXP Processor 225MHz & $32 \mathrm{MB}$ \\
\hline Zinwell ZBT 620N & MSTAR MSD7828L 216MHz & $128 \mathrm{MB}$ \\
\hline Samsung DCB-B270R & Nec emma2 166MHz & $16 \mathrm{MB}$ \\
\hline
\end{tabular}

Para classificar a potência computacional dos receptores de propósito geral foi utilizada uma página chamada CPU Benchmarks (CPUBenchmarks, 2011) que apresenta a classificação de diversos processadores disponíveis no mercado. Essa página apresenta os resultados obtidos pelo benchmark PassMark que realiza uma comparação entre centenas de processadores utilizando os resultados dos usuários do software Performance Test. O Performance Test é um software que realiza uma avaliação de desempenho dos computadores dos usuários e gera uma métrica chamada PassMark que é utilizada pela página CPU Benchmarks para classificar os diversos processadores existentes. Assim, todos os processadores de propósito geral analisados neste trabalho foram organizados obedecendo à ordem em que aparecem nessa página, onde os processadores com maior valor de PassMark correspondem aos processadores mais potentes. A Tabela 5.2 apresenta a classificação dos receptores digitais que utilizam processadores de propósito geral utilizando o benchmark PassMark.

No simulador GridSim a potência computacional de um determinado recurso e o total de computação necessária para a execução de uma aplicação são dados em MIPS (Milhões de Instruções Por Segundo). Como não foi localizado o valor de MIPS para a maioria dos processadores analisados, tornou-se necessária uma conversão de outras informações conhecidas para MIPS. Essa conversão não é imediata, uma vez que não existe uma relação direta entre os dados obtidos e MIPS. 
Tabela 5.2: Classificação dos Receptores Digitais que Utilizam Processadores de Propósito Geral.

\begin{tabular}{|c|c|c|c|c|c|c|}
\hline Classe & Posição & Equipamento & Processador & Memória & PassMark & MIPS \\
\hline \multirow{5}{*}{1} & $1^{0}$ & Niveus Pro Series & Intel Core i7 950 3.07GHz & $4 G B$ & 6338 & 88416 \\
\hline & $2^{\circ}$ & Media Center Idea 3900 & Intel Core 2 Quad Q9650 3.0GHz & $4 \mathrm{~GB}$ & 4606 & 64255 \\
\hline & $3^{\circ}$ & Niveus Media Denali & Intel Core 2 Duo E8600 3.3GHz & $4 \mathrm{~GB}$ & 2653 & 37010 \\
\hline & $4^{0}$ & Megahome MWX & Intel Core 2 Duo E8400 3.0GHz & $4 \mathrm{~GB}$ & 2245 & 31318 \\
\hline & $5^{0}$ & Munddo & Intel Core 2 Duo T9800 2.93GHz & $4 \mathrm{~GB}$ & 2199 & 30676 \\
\hline \multirow{6}{*}{2} & $6^{0}$ & Vida Box Slim & AMD Athlon $64 \mathrm{X} 26000+2.0 \mathrm{GHz}$ & $2 \mathrm{~GB}$ & 1643 & 22920 \\
\hline & $7^{\circ}$ & Daten Home PC Slim & AMD Athlon 64 X2 4200+2.2GHz & $2 \mathrm{~GB}$ & 1153 & 16085 \\
\hline & $8^{\circ}$ & Daten Home PC & AMD Athlon 64 X2 $3800+2.0 \mathrm{GHz}$ & $2 \mathrm{~GB}$ & 1044 & 14564 \\
\hline & 9o & Replay Plus Viewvox 1000 & AMD Athlon $643500+2.2 \mathrm{GHz}$ & $2 \mathrm{~GB}$ & 568 & 7924 \\
\hline & $10^{\circ}$ & Inteset Denzel & Intel Pentium 4 3.2GHz & $1 \mathrm{~GB}$ & 524 & 7309 \\
\hline & $11^{\circ}$ & Philips Showline & Intel Pentium 4 3.0GHz & $512 \mathrm{MB}$ & 491 & 6849 \\
\hline
\end{tabular}

Dos processadores analisados, apenas o manual do processador AMD Athlon 64 X2 $3800+$ 2.0GHz apresentou a informação referente ao seu MIPS. Essa informação, junto com os valores da coluna PassMark, foi utilizada para determinar os demais valores da coluna MIPS correspondentes aos outros processadores, considerando a proporcionalidade entre os valores do benchmark e dos MIPS. Com os valores obtidos foi gerada a Tabela 5.2.

No caso dos processadores de aplicações específicas, o site CPU Benchmarks não informa os seus respectivos valores de PassMark. Assim, o processador Broadcom $1122400 \mathrm{MHz}$, que de acordo com o seu manual realiza 880 MIPS, foi utilizado como base para o cálculo dos valores da coluna MIPS dos demais processadores. No entanto, ao invés de utilizar informações da coluna PassMark, foram utilizados os valores correspondentes a potência de cada processador descritas em MHz, obtendo-se a classificação apresentada na Tabela 5.3.

Tabela 5.3: Classificação dos Receptores Digitais que Utilizam Processadores Específicos.

\begin{tabular}{|c|l|l|l|c|c|c|}
\hline Classe & Posição & \multicolumn{1}{|c|}{ Equipamento } & \multicolumn{1}{|c|}{ Processador } & Memória & PassMark & MIPS \\
\hline \multirow{5}{*}{3} & $12^{\circ}$ & Samsung RNG-150 & Broadcom $1122400 \mathrm{MHz}$ & $512 \mathrm{MB}$ & - & 880 \\
\cline { 2 - 7 } & $13^{\circ}$ & Zinwel ZBT 601 & Broadcom 7402 300MHz & $128 \mathrm{MB}$ & - & 660 \\
\cline { 2 - 7 } & $14^{\circ}$ & VisionTec VT7000 & STI 7100 300MHz & $128 \mathrm{MB}$ & - & 660 \\
\cline { 2 - 7 } & $15^{\circ}$ & DigiTV HD & Sti 7100 ST40 266MHz & $128 \mathrm{MB}$ & - & 585 \\
\cline { 2 - 7 } & $16^{\circ}$ & Audio Vision HD031i & SH-3 266MHz & $256 \mathrm{MB}$ & - & 585 \\
\cline { 2 - 7 } & $17^{\circ}$ & Samsung SMT-H1501 & Zoran ZR391055 250MHz & $160 \mathrm{MB}$ & - & 550 \\
\cline { 2 - 7 } & $18^{\circ}$ & Samsung SMT-H3050 & Conexant CX2417X 250MHz & $128 \mathrm{MB}$ & - & 550 \\
\cline { 2 - 7 } & $19^{\circ}$ & Samsung SMT-2110C & NXP Processor 225MHz & $32 \mathrm{MB}$ & - & 495 \\
\cline { 2 - 7 } & $20^{\circ}$ & Zinwell ZBT 620N & MSTAR MSD7828L 216MHz & $128 \mathrm{MB}$ & - & 475 \\
\cline { 2 - 7 } & $21^{\circ}$ & Samsung DCB-B270R & Nec emma2 166MHz & $16 \mathrm{MB}$ & - & 365 \\
\hline
\end{tabular}

Com o preenchimento da coluna MIPS, foi realizada uma classificação dos equipamentos de acordo com a sua potência computacional, conforme apresentado na Tabela 5.4, onde, por exem- 
plo, os equipamentos da Classe 1 são aqueles que possuem uma potência computacional maior ou igual a 25000 MIPS.

Tabela 5.4: Classificação dos Recursos.

\begin{tabular}{|c|c|}
\hline Classe & MIPS \\
\hline 1 & $>=25000$ \\
\hline 2 & $>=1000<25000$ \\
\hline 3 & $<1000$ \\
\hline
\end{tabular}

Essa classificação foi importante, pois com os resultados obtidos, definiu-se três classes de equipamentos, as quais foram utilizadas nos ambientes simulados. Definidas as classes, foi realizada uma caracterização das aplicações interativas disponíveis para saber que tipos de aplicação esses equipamentos suportam.

\subsubsection{Classificação das Aplicações Interativas}

No GridSim as aplicações são as cargas de trabalho utilizadas na simulação e possuem os seguintes elementos:

- Length (MIPS): representa o total de computação necessário para a execução daquela aplicação, ou seja, o número de milhões de instruções que serão executadas;

- File: representa o tamanho do arquivo a ser transmitido;

- Out: representa o tamanho do arquivo de retorno com a resposta obtida.

Para a definição da carga de trabalho, foi realizado um estudo sobre as características das aplicações interativas como, por exemplo, a quantidade de processamento que uma determinada aplicação necessita para ser executada. No entanto, não foram encontrados na literatura trabalhos relacionados a este assunto. Sendo assim, foi realizada uma avaliação de nove aplicações disponíveis na página Clube NCL (ClubeNCL, 2011). Esta página permite que os desenvolvedores de aplicações interativas disponibilizem os seus projetos para que outros usuários os utilizem.

Essas aplicações foram executadas em um receptor digital virtualizado chamado Set-top Box Virtual Ginga-NCL, que é uma máquina virtual construída para facilitar o processo de distribuição e implantação do Ginga-NCL (um dos subsistemas do middleware Ginga). Esse Set-top Box virtualizado (implementado em $\mathrm{C}++$ ) conta com os mais avançados recursos de apresentação de aplicações declarativas, melhor desempenho e maior proximidade de uma implementação embarcada em receptores reais. Além disso, foi utilizado o processador Intel Core 2 Duo $2.2 \mathrm{GHz}$ para a execução das aplicações e do receptor virtualizado. 
Durante as execuções foram avaliados momentos sem nenhum tipo de interação com a aplicação e momentos com diferentes tipos de interações. O objetivo era explorar todas as funcionalidades disponíveis e obter informações sobre o percentual de processamento utilizado nas execuções. Os resultados obtidos são apresentados na Tabela 5.5.

Tabela 5.5: Porcentagem de Uso do Processador.

\begin{tabular}{|l|c|c|c|c|}
\hline \multicolumn{1}{|c|}{ Aplicação } & \% Uso Processador & Desvio Padrão & Valor Máximo & MIPS \\
\hline Jogo da Velha & 9,88 & 3,82 & 30,20 & 1754 \\
\hline Ginga Hero & 50,68 & 1,56 & 54,00 & 8999 \\
\hline Hackerteen & 53,39 & 17,68 & 92,00 & 9482 \\
\hline Tur_Ma & 38,22 & 6,34 & 93,00 & 6788 \\
\hline Primeiro João & 63,40 & 4,52 & 91,20 & 11259 \\
\hline Viva Mais Peso & 65,19 & 1,84 & 76,40 & 11576 \\
\hline Viva Mais Pratos & 63,64 & 3,24 & 70,60 & 11302 \\
\hline Porta Retrato & 60,05 & 5,97 & 91,50 & 10663 \\
\hline Comercial Proview & 51,73 & 1,86 & 62,00 & 9187 \\
\hline
\end{tabular}

Analisando a Tabela 5.5 tem-se que a coluna \% Uso Processador corresponde à porcentagem que a aplicação utilizou, em média, durante a sua execução. A coluna Valor Máximo corresponde ao percentual máximo do processador que a aplicação chegou a utilizar durante a sua execução. Por fim, a coluna MIPS corresponde à quantidade de MIPS necessária para a execução da aplicação. Este valor foi obtido através da monitoração da execução das aplicações no processador Intel Core 2 Duo $2.2 \mathrm{GHz}$. Com os resultados obtidos foram definidos quatro tipos de aplicações conforme apresentado na Tabela 5.6.

Tabela 5.6: Uso do Processador em MIPS.

\begin{tabular}{|c|c|c|}
\hline Tipo & Porcentagem & Porcentagem Média \\
\hline Leve & $<20 \%$ & $10 \%$ \\
\hline Média & $>=20 \%<40 \%$ & $30 \%$ \\
\hline Pesada & $>=40 \%<70 \%$ & $55 \%$ \\
\hline Muito Pesada & $>=70 \%$ & $85 \%$ \\
\hline
\end{tabular}

$\mathrm{Na}$ Tabela 5.6 as aplicações do tipo Leve são aquelas que durante a sua execução consomem entre 0 e $20 \%$ do processador, $10 \%$ em média. As aplicações do tipo Média são aquelas que consomem entre $20 \%$ e $40 \%$ do processador, 30\% em média. Já as aplicações do tipo Pesada, consomem entre $40 \%$ e $70 \%$ do processador, $55 \%$ em média, e por fim, as aplicações do tipo Muito Pesada, consomem entre $70 \%$ e $100 \%$ do processador, $85 \%$ em média.

Esses quatro tipos de aplicações foram utilizados para simular a sobrecarga que eles impõem sobre as classes de receptores definidas na Seção anterior e para a composição de duas cargas: Carga Baixa e Carga Alta. Essas cargas correspondem a um conjunto de aplicações que são executadas pelos receptores que compõem as federações do ambiente simulado. Cada nível de carga é 
composto por diferentes percentuais dos tipos de aplicações apresentados na Tabela 5.6. A Tabela 5.7 mostra esta composição.

Tabela 5.7: Composição das Cargas Simuladas.

\begin{tabular}{|c|c|c|c|}
\hline Tipo & \% Aplicações Carga Baixa & \% Aplicações Carga Alta & \% Médio Uso Processador \\
\hline Leve & $48 \%$ & $39 \%$ & $10 \%$ \\
\hline Média & $40 \%$ & $6 \%$ & $30 \%$ \\
\hline Pesada & $6 \%$ & $7 \%$ & $55 \%$ \\
\hline Muito Pesada & $6 \%$ & $48 \%$ & $85 \%$ \\
\hline
\end{tabular}

Na carga Baixa, de todas as aplicações que são submetidas para execução, ou seja, de $100 \%$ das aplicações, $48 \%$ são do tipo Leve, $40 \%$ do tipo Média, $6 \%$ do tipo Pesada e $6 \%$ do tipo Muito Pesada. Cada aplicação utiliza, em média, 10\%, 30\%, 55\% e 85\% do processador na sua execução, respectivamente. Quando uma carga Alta é analisada, de todas as aplicações que são submetidas para execução (ou seja, de 100\% das aplicações), 39\% são do tipo Leve, $6 \%$ do tipo Média, $7 \%$ do tipo Pesada e $48 \%$ do tipo Muito Pesada. Cada aplicação utiliza, em média, 10\%, 30\%, 55\% e $85 \%$ do processador na sua execução, respectivamente.

Com esses percentuais atribuídos a cada tipo de aplicação na composição das cargas Baixa e Alta, mantém-se a proporção de $100 \%$ de aumento da carga Baixa para a Alta. A mesma proporção é mantida nos outros fatores que compõem o ambiente simulado neste trabalho para análise de três políticas de escalonamento, conforme apresentado na Seção 6.2 do próximo Capítulo.

\subsubsection{Políticas de Escalonamento}

Após a caracterização e classificação dos receptores e aplicações disponíveis, foram definidas três políticas de escalonamento. Essas políticas são responsáveis pela distribuição das aplicações para as federações que compõem a grade computacional simulada.

\section{WorkQueue (WQ)}

Muito utilizada em grades computacionais, essa política não utiliza nenhuma informação sobre o ambiente ou sobre a aplicação para atribuir tarefas aos recursos disponíveis. Assim que os recursos se tornam disponíveis, as aplicações são atribuídas a eles. Essa distribuição é feita de forma aleatória, bastando que o recurso esteja disponível e que exista aplicação para ser escalonada. Assim que uma aplicação é executada, os resultados são enviados de volta ao escalonador que por sua vez atribui uma nova aplicação ao recurso. Isso persiste até que todas as aplicações sejam executadas. Com isso, as federações com maior potência computacional receberão mais aplicações para executarem (Rodamilans, 2009). 


\section{Baseada na Capacidade (BC)}

Proposta neste trabalho, essa política leva em consideração a federação com maior potência computacional. Essa política analisa a capacidade de processamento ${ }^{1}$ de cada federação, descobre a que possui maior potência computacional e o quanto ela é mais potente que as demais. Isso é feito da seguinte forma: suponha um ambiente com quatro federações F0, F1, F2 e F3, onde a capacidade de processamento é 359204 MIPS, 305270 MIPS, 315741 MIPS e 401869 MIPS, respectivamente (lembrando que a potência computacional de um recurso no simulador GridSim é dada em MIPS). Analisando as quatro federações, percebe-se que F3 é 10,61\% mais potente que F0, 24,03\% mais potente que F1 e 21,43\% mais potente que F2. Em seguida, essa política soma a diferença de capacidade de processamento da federação mais potente em relação às demais e gera uma média chamada Capacidade Média de Processamento (CMP), que indica o quanto uma determinada federação é, em média, mais potente que as demais. Voltando ao exemplo dado, tem-se a equação 5.1 .

$$
C M P=\left(\frac{10.61+24.03+21.43}{3}\right)
$$

De acordo com essa equação, F3 é, em média, 18,69\% mais potente que as demais federações. Essa CMP indicará quantas aplicações uma federação receberá a mais em relação às demais, conforme apresentado na Tabela 5.8.

Tabela 5.8: Atribuição do Número de Aplicações.

\begin{tabular}{|c|c|}
\hline CMP & Número de Aplicações \\
\hline$<10$ & 1 \\
\hline$>=10<20$ & 2 \\
\hline$>=20<30$ & 3 \\
\hline$>=30<40$ & 4 \\
\hline
\end{tabular}

Assim, de acordo com a Tabela 5.8, F3 receberá duas aplicações a mais que as demais federações, ou seja, para cada aplicação que as demais federações receberem, F3 receberá duas.

\section{Melhor Arranjo (MA)}

Também proposta neste trabalho, essa política analisa a carga (Baixa ou Alta) que é aplicada ao sistema. Se for uma carga Baixa, a política atribui as menores aplicações para as máquinas com maior potência computacional. Isso visa o aumento do throughput, pois os melhores recursos são liberados mais rapidamente, podendo assim executar novas aplicações. No caso de uma carga

\footnotetext{
${ }^{1}$ Obtida através da soma da capacidade de processamento de cada receptor que compõem uma federação (filial da emissora).
} 
Alta, a política atribui as maiores aplicações para as máquinas com maior potência computacional. Isso conduz para um melhor balanceamento de carga e melhor tempo de execução total.

No ambiente simulado, sempre que a política utilizada necessitar de informações sobre os receptores disponíveis, o escalonador pode acessar de forma dinâmica o DGI (Diretório Global de Informações).

Após a caracterização de cada entidade utilizada na simulação foram realizados experimentos para verificar a sobrecarga imposta por cada tipo de aplicação, definidos na Tabela 5.6, sobre as classes de equipamentos, definidas na Tabela 5.4. Após esses experimentos foram realizadas simulações comparando as três políticas de escalonamento definidas nesta Seção. A configuração dos experimentos do primeiro caso citado é apresentada na próxima Seção.

\subsection{Projeto dos Experimentos de Análise de Sobrecarga}

Nos experimentos realizados foram analisados ambientes compostos por apenas uma classe de equipamentos, ou seja, não houve heterogeneidade de classes de equipamentos. O objetivo é analisar o Tempo Médio de Resposta obtido com a execução dos quatro tipos de aplicações nos equipamentos Classe 1, 2 e 3 e ver o quanto o desempenho do sistema pode ser prejudicado, como por exemplo, na execução de uma aplicação do tipo Muito Pesada em um equipamento Classe 3.

Foram considerados quatro fatores, um com quatro níveis, um com três e dois fatores com dois níveis. A seguir são apresentados os fatores e seus respectivos níveis.

- A - Número de Equipamentos: 50 e 100;

- B - Tipo de Equipamento: Classe 1, 2 e 3;

- C - Número de Usuários: 30 e 60;

- D - Carga: Leve, Média, Pesada e Muito Pesada.

Além desses fatores foram definidos três fatores fixos:

- Política de Escalonamento: WorkQueue (WQ);

- Número de Aplicações: 50 para cada usuário;

- Número de Federações: 1 .

A variável de saída considerada nos gráficos das Figuras 5.2, 5.3, 5.4, 5.5 e 5.6 é o valor médio obtido para o tempo de resposta e o intervalo de confiança (considerando 95\% de confiança) calculado baseando-se em 10 execuções $^{2}$ da simulação.

\footnotetext{
${ }^{2}$ Através das 10 repetições percebeu-se que os resultados obtidos para cada variável de resposta não apresentavam grandes variações. Por isso, concluiu-se que 10 era um número razoável para a quantidade de repetições.
} 


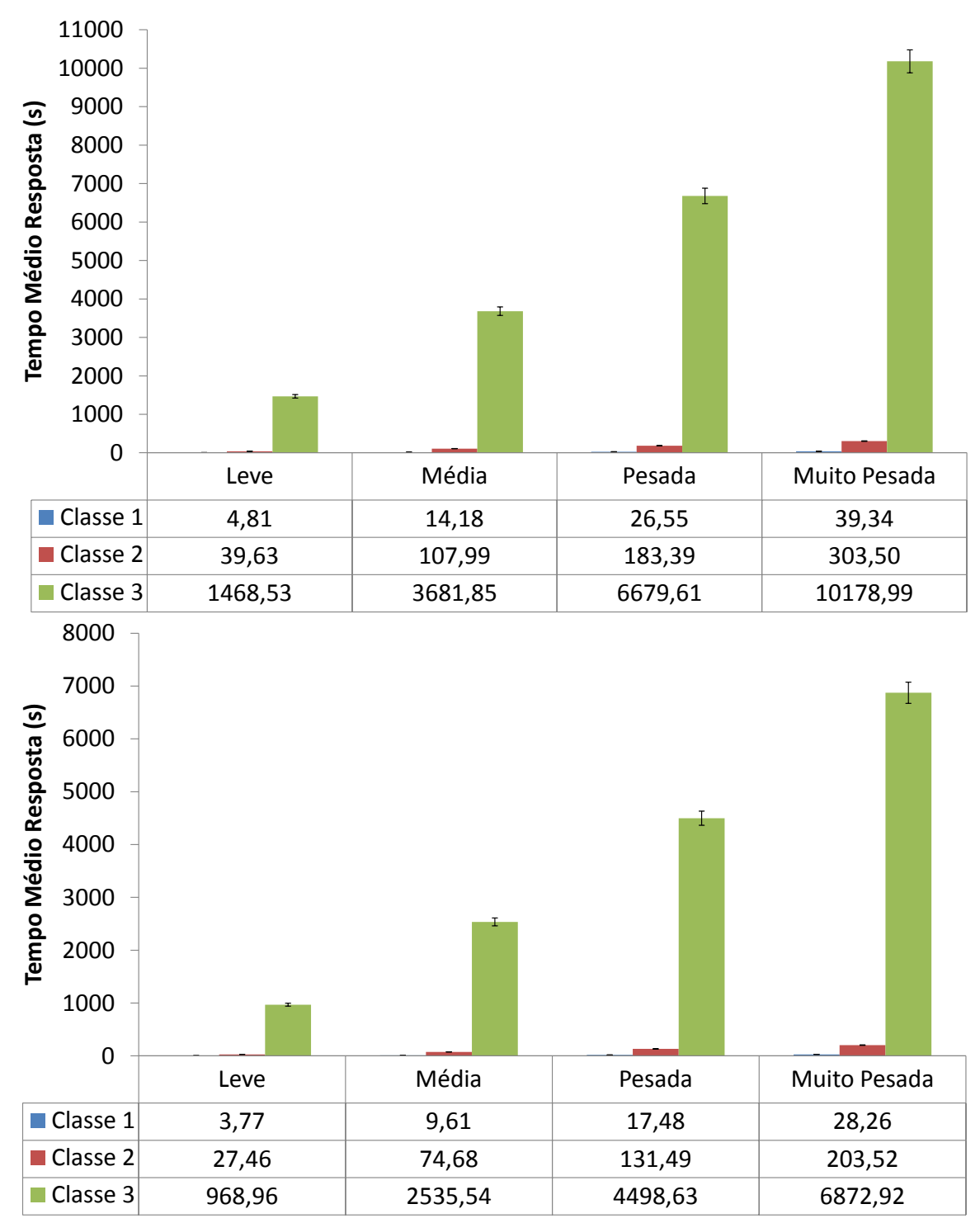

Figura 5.2: Tempo Médio de Resposta com 30 usuários e 50 e 100 equipamentos.

Os gráficos apresentados nas Figuras 5.2 e 5.3 mostram o Tempo Médio de Resposta, dado em segundos, gasto pelos equipamentos das Classes 1, 2 e 3 na execução das aplicações dos tipos Leve, Média, Pesada e Muito Pesada feitas por 30 e 60 usuários, respectivamente.

Com os resultados obtidos observa-se que o tempo necessário para a execução de qualquer tipo de aplicação em equipamentos da Classe 3 é proibitivo. Mesmo para aplicações Leves, o Tempo Médio de Resposta ultrapassa vinte minutos, o que é inviável para aplicações interativas. Conforme a complexidade das aplicações aumenta, esses tempos tornam-se ainda maiores e, para equipamentos da Classe 3, mais de duas horas são necessárias para a execução. Quando equipamentos da Classe 2 são considerados, observa-se que a execução de aplicações Leves tornam-se viáveis, embora ainda tempos relativamente altos são obtidos. Para os equipamentos da Classe 1, observa-se valores consideravelmente menores, viabilizando todos os tipos de aplicações. Com a utilização de cem equipamentos, observa-se um comportamento similar, com tempos inferiores. 


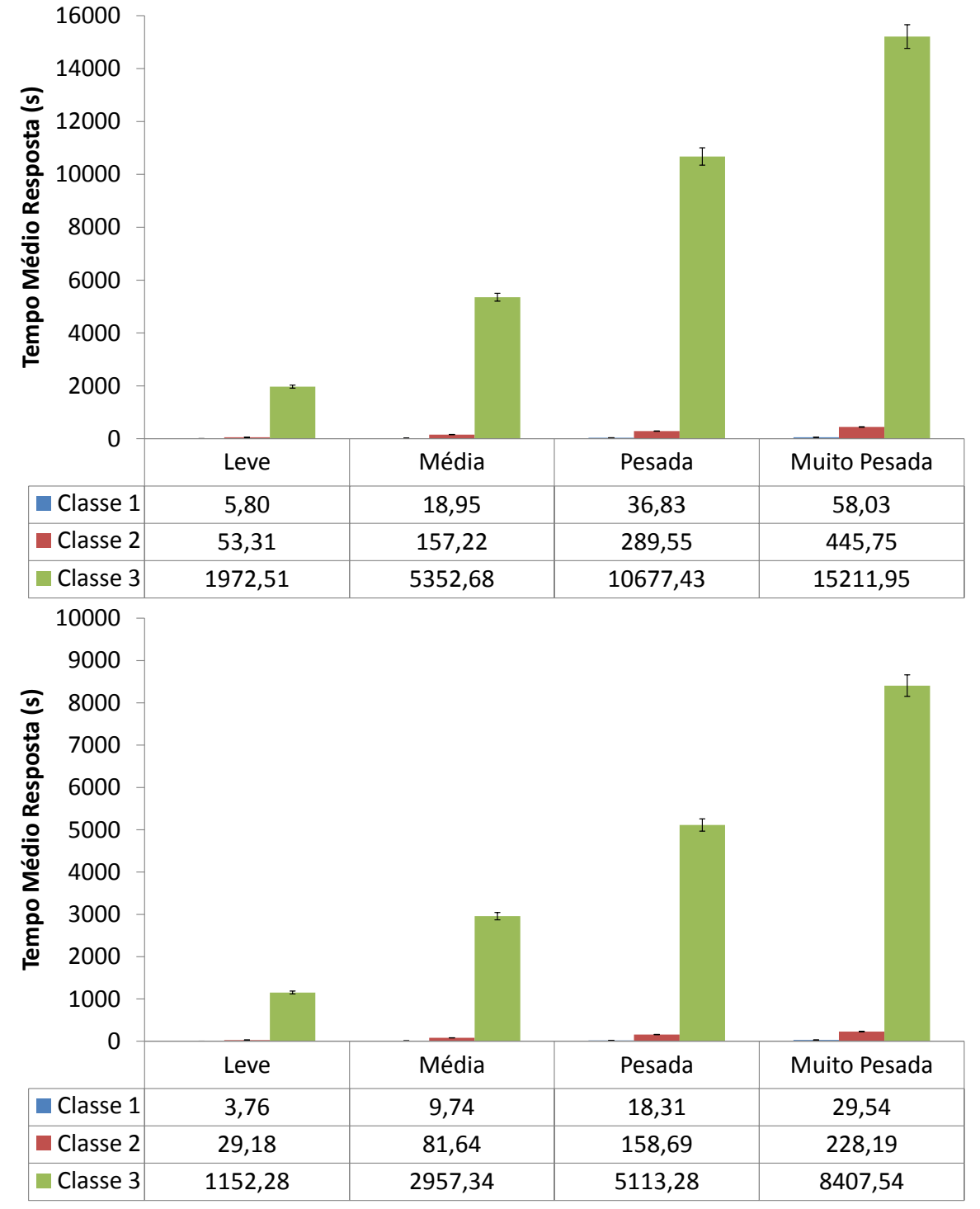

Figura 5.3: Tempo Médio de Resposta com 60 usuários e 50 e 100 equipamentos.

Em uma grade computacional composta apenas por equipamentos da Classe 3, o desempenho do sistema na execução das aplicações é bastante comprometido. Analisando separadamente cada classe de equipamentos verifica-se que, por serem menos potentes, os equipamentos Classe 3 apresentam Tempos Médios de Resposta maiores que os obtidos nos experimentos com Classe $1 \mathrm{e}$ Classe 2. Esses dados são apresentados nos gráficos das Figuras 5.4, 5.5 e 5.6. 


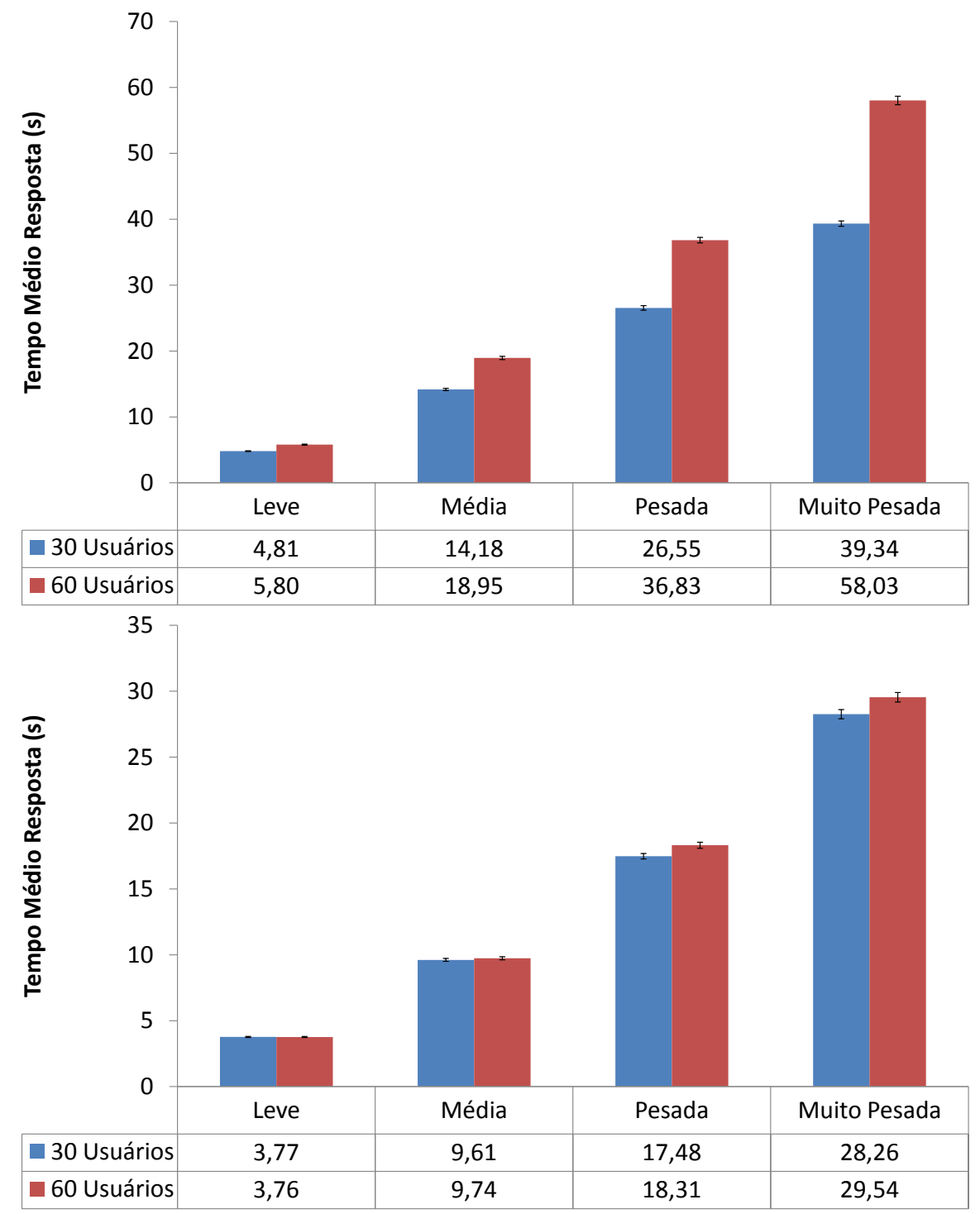

Figura 5.4: Tempo Médio de Resposta em 50 e 100 Equipamentos Classe 1.

Considerando um ambiente composto por cinquenta equipamentos Classe 1 verifica-se que o aumento de $100 \%$ do número de clientes, ou seja, de 30 para 60 , não mantém a mesma proporção com relação ao aumento do Tempo Médio de Resposta. Assim, na Figura 5.4, na execução das aplicações dos tipos Leve, Média, Pesada e Muito Pesada, o aumento no Tempo Médio de Resposta varia entre $17 \%$ e $32 \%$ com o aumento do número de clientes. Com a utilização de cem equipamentos, observa-se que a variação é muito menor, entre $0 \%$ e $5 \%$. 


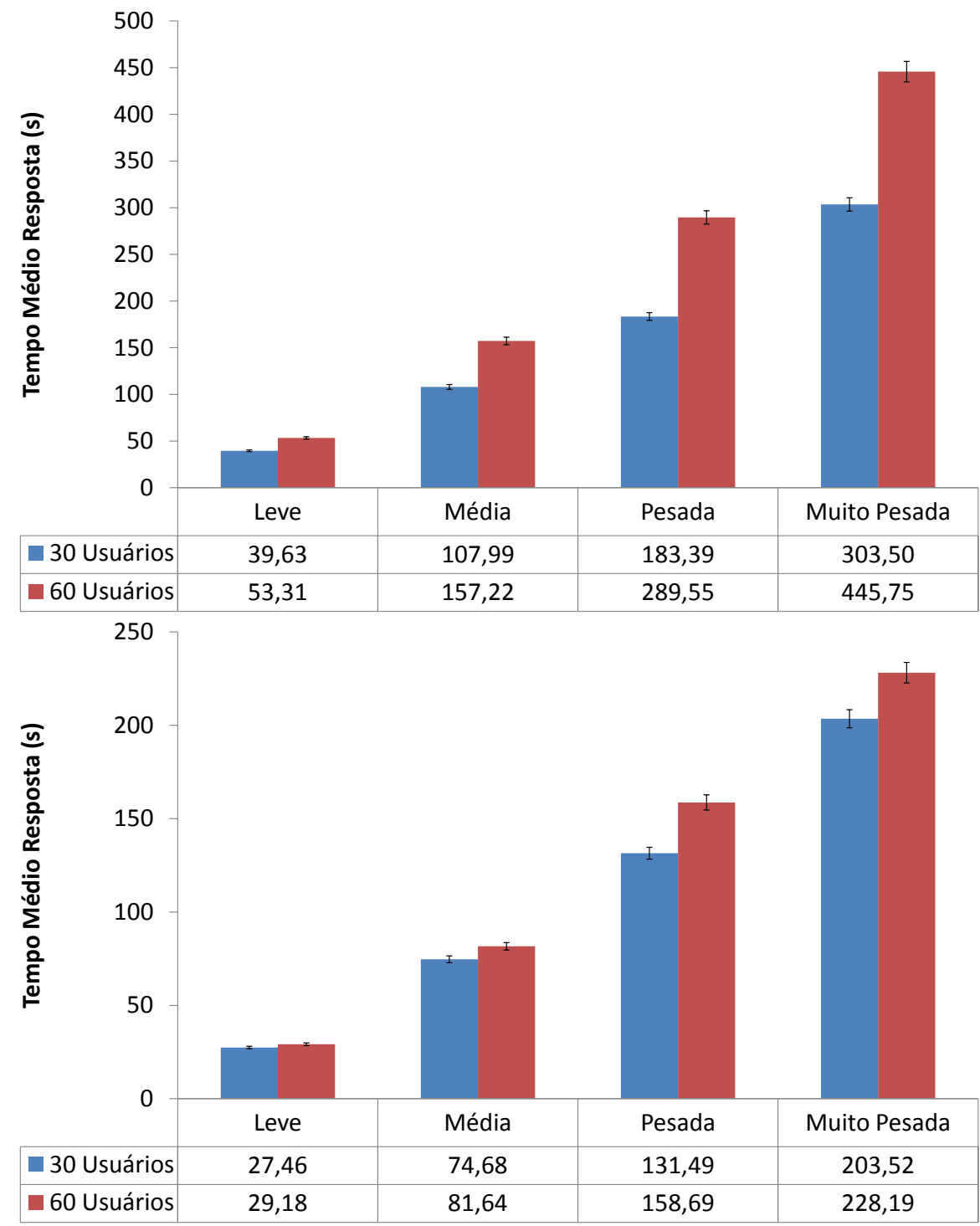

Figura 5.5: Tempo Médio de Resposta em 50 e 100 Equipamentos Classe 2.

Na Figura 5.5, considerando um ambiente composto por cinquenta equipamentos Classe 2 verifica-se que o aumento de $100 \%$ do número de clientes, proporciona um aumento no Tempo Médio de Resposta que varia entre $25 \%$ e $37 \%$ na execução das aplicações dos tipos Leve, Média, Pesada e Muito Pesada. Com a utilização de cem equipamentos, observa-se que a variação é menor, entre $6 \%$ e $18 \%$. 


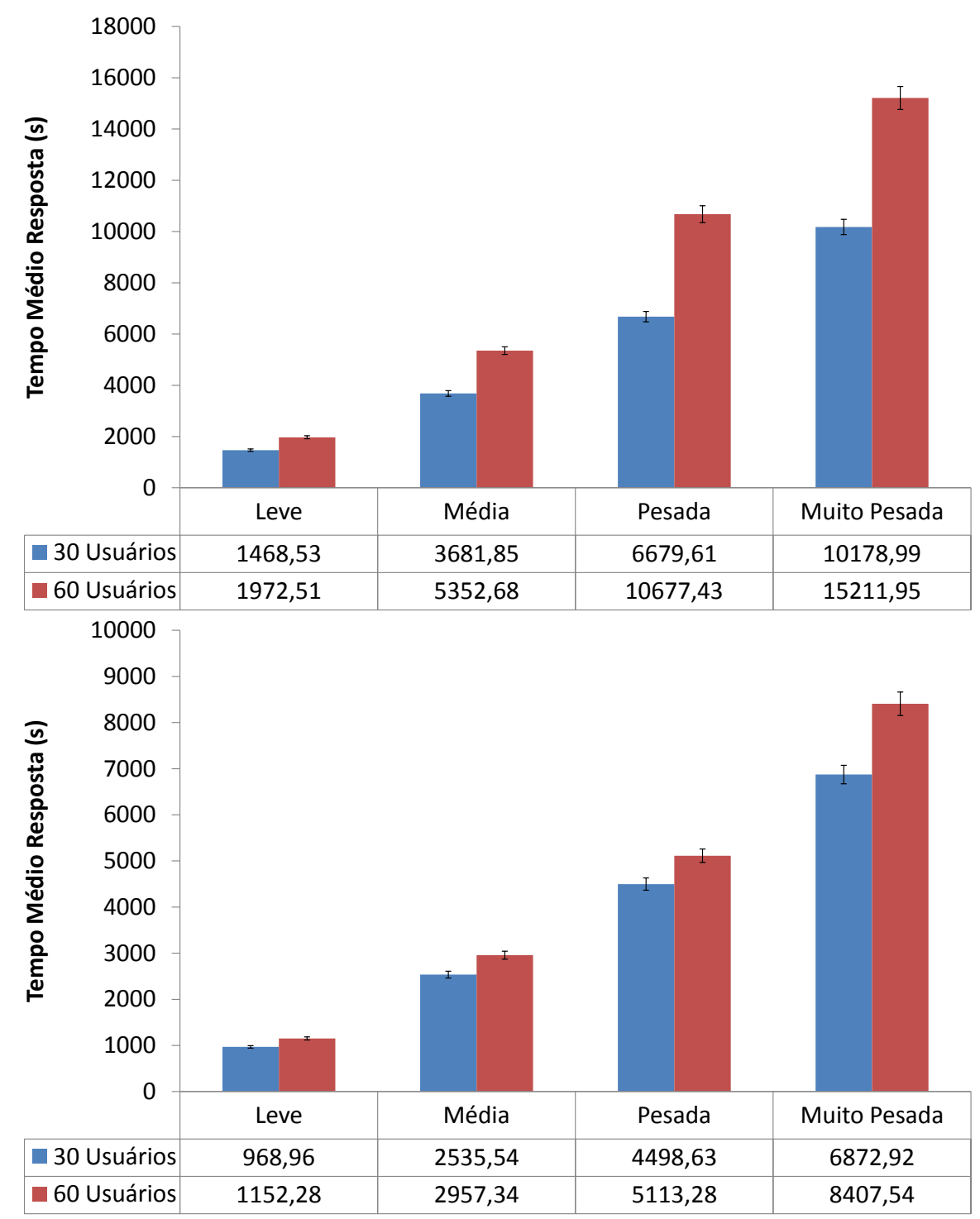

Figura 5.6: Tempo Médio de Resposta em 50 e 100 Equipamentos Classe 3.

Por fim, na Figura 5.6, onde tem-se um ambiente composto por cinquenta equipamentos Classe 3 verifica-se que o aumento de $100 \%$ do número de clientes, proporciona um aumento no Tempo Médio de Resposta que varia entre $26 \%$ e $38 \%$ na execução das aplicações dos tipos Leve, Média, Pesada e Muito Pesada. Com a utilização de cem equipamentos, observa-se que a variação é entre $12 \%$ e $19 \%$.

Após a execução desses experimentos foi realizada a configuração do modelo fatorial completo apresentado no próximo Capítulo. Com essa configuração foram realizados experimentos considerando um ambiente heterogêneo composto por equipamentos da Classe 1, 2 e 3. O objetivo desse experimento é comparar três políticas de escalonamento: WQ, BC e MA. 



\section{CAPÍTULO \\ 6 \\ Avaliação de Algoritmos de \\ Escalonamento}

\subsection{Considerações Iniciais}

Neste Capítulo são apresentados os resultados obtidos nos experimentos realizados utilizando o simulador GridSim com o intuito de avaliar três algoritmos de escalonamento aplicados em uma grade computacional composta por receptores digitais de televisão. A grade computacional considerada baseia-se no ambiente proposto pelo Grid Anywhere. Foram utilizados os resultados dos estudos dos equipamentos com a funcionalidade de recepção de sinal digital e dos estudos das aplicações interativas apresentados no Capítulo 5.

\subsection{Projeto dos Experimentos}

Nos resultados apresentados neste Capítulo, são considerados quatro fatores, três com dois níveis e um fator com três níveis. A seguir são apresentados os fatores e seus respectivos níveis. Cada nível superior segue uma porcentagem de $100 \%$ de aumento em relação ao nível inferior, com exceção dos níveis do fator Política de Escalonamento:

- A - Número de Federações (filiais da emissora): 2 e 4;

- B - Política de Escalonamento: WorkQueue (WQ), Baseada na Capacidade (BC) e Melhor Arranjo (MA); 
- C - Número de Usuários: 30 e 60;

- D - Carga: Baixa e Alta.

Além desses fatores foram definidos dois fatores fixos:

- Número de Aplicações: cada usuário executa 50 aplicações. Uma aplicação pode ser de qualquer um dos tipos apresentados na Tabela 5.6 e a potência computacional exigida por ela durante a sua execução obedece ao seu intervalo apresentado na coluna MIPS da mesma Tabela. No ambiente simulado, esse intervalo é utilizado para gerar um número aleatório que define a potência computacional exigida por uma aplicação.

- Número de Recursos (receptores): 12 em cada federação, dos quais três são da Classe 1, três da Classe 2 e três da Classe 3. A potência computacional de um recurso, dada em MIPS no simulador GridSim, é gerada aleatoriamente através do intervalo definido na coluna MIPS da Tabela 5.4.

Neste trabalho foi utilizado o modelo fatorial completo que mede cada uma das variáveis de resposta utilizando a combinação entre todos os níveis dos fatores. Um planejamento fatorial completo para $N$ fatores com $k$ níveis exige $N^{k}$ experimentos (Jain, 1991). Neste trabalho, como o fator Política (B) possui três níveis, tem-se $\left(N^{k}+2^{3}\right)$, onde $2^{3}$ corresponde às interações adicionadas com o terceiro nível do fator Política. Assim, foram realizados experimentos para os fatores Número de Federações (A), Política (B), Número de Usuários (C) e Carga (D) onde os níveis de cada fator foram variados gerando a Tabela 6.1. As variáveis de resposta obtidas e analisadas foram: o Tempo Médio de Resposta (TMR) (obtido através da equação 6.1) e o Throughput Médio (TM) (equação 6.2).

$$
\begin{gathered}
T M R=\frac{\sum_{i, j} \text { TempodeExecucao }_{i j}}{\text { NumerodeRequisicoes }} \\
T M=\frac{\text { NumerodeRequisicoes }}{\sum_{i, j} \text { TempodeExecucao }_{i j}}
\end{gathered}
$$

A próxima Seção apresenta os resultados dos experimentos realizados com os fatores e níveis definidos obedecendo às combinações apresentadas na Tabela 6.1. Todos os experimentos foram executados 10 vezes $^{1}$ e os resultados apresentados referem-se à média dos resultados e ao intervalo de confiança com $95 \%$ de confiança.

\footnotetext{
${ }^{1}$ Através das 10 repetições percebeu-se que os resultados obtidos para cada variável de resposta não apresentavam grandes variações. Por isso, concluiu-se que 10 era um número razoável para a quantidade de repetições.
} 
Tabela 6.1: Configuração do Modelo Fatorial.

\begin{tabular}{|c|c|c|c|c|}
\hline & No Federações & Política & No Usuários & Carga \\
\hline Exp & A & B & C & D \\
\hline $\mathbf{1}$ & 2 & WorkQueue & 30 & Baixa \\
\hline $\mathbf{2}$ & 2 & WorkQueue & 30 & Alta \\
\hline $\mathbf{3}$ & 2 & WorkQueue & 60 & Baixa \\
\hline $\mathbf{4}$ & 2 & WorkQueue & 60 & Alta \\
\hline $\mathbf{5}$ & 2 & Baseada na Capacidade & 30 & Baixa \\
\hline $\mathbf{6}$ & 2 & Baseada na Capacidade & 30 & Alta \\
\hline $\mathbf{7}$ & 2 & Baseada na Capacidade & 60 & Baixa \\
\hline $\mathbf{8}$ & 2 & Baseada na Capacidade & 60 & Alta \\
\hline $\mathbf{9}$ & 2 & Melhor Arranjo & 30 & Baixa \\
\hline $\mathbf{1 0}$ & 2 & Melhor Arranjo & 30 & Alta \\
\hline $\mathbf{1 1}$ & 2 & Melhor Arranjo & 60 & Baixa \\
\hline $\mathbf{1 2}$ & 2 & Melhor Arranjo & 60 & Alta \\
\hline $\mathbf{1 3}$ & 4 & WorkQueue & 30 & Baixa \\
\hline $\mathbf{1 4}$ & 4 & WorkQueue & 30 & Alta \\
\hline $\mathbf{1 5}$ & 4 & WorkQueue & 60 & Baixa \\
\hline $\mathbf{1 6}$ & 4 & WorkQueue & 60 & Alta \\
\hline $\mathbf{1 7}$ & 4 & Baseada na Capacidade & 30 & Baixa \\
\hline $\mathbf{1 8}$ & 4 & Baseada na Capacidade & 30 & Alta \\
\hline $\mathbf{1 9}$ & 4 & Baseada na Capacidade & 60 & Baixa \\
\hline $\mathbf{2 0}$ & 4 & Baseada na Capacidade & 60 & Alta \\
\hline $\mathbf{2 1}$ & 4 & Melhor Arranjo & 30 & Baixa \\
\hline $\mathbf{2 2}$ & 4 & Melhor Arranjo & 30 & Alta \\
\hline $\mathbf{2 3}$ & 4 & Melhor Arranjo & 60 & Baixa \\
\hline $\mathbf{2 4}$ & 4 & Melhor Arranjo & 60 & Alta \\
\hline
\end{tabular}

\subsection{Tempo Médio de Resposta}

Nos gráficos apresentados nas Figuras 6.1 e 6.2 observa-se que em todos os experimentos com 2 e 4 federações, a política Melhor Arranjo (MA) obteve menor Tempo Médio de Resposta, medido em segundos (s), comparada com as políticas WorkQueue (WQ) e Baseada na Capacidade (BC). Isso ocorre, pois, na política MA tem-se um maior balanceamento de carga, visto que o escalonador busca no DGI informações sobre a composição da carga que será submetida ao sistema e sobre as federações disponíveis. Em caso de carga Baixa, as aplicações dos tipos Leve e Média, que exigem menos potência computacional para serem executadas (Tabela 5.6), são enviadas para as federações com maior potência computacional. Isso visa o aumento do Throughput Médio, pois os melhores recursos são liberados mais rapidamente, podendo assim executar novas aplicações. Em caso de carga Alta, as aplicações dos tipos Pesada e Muito Pesada, que exigem mais potência computacional para serem executadas (Tabela 5.6), são enviadas para as federações mais potentes. Isso conduz para um melhor balanceamento de carga e menor tempo de execução total.

Na política BC, o escalonador busca no DGI apenas informações sobre as federações disponíveis. Através dessas informações ele gera uma média, chamada Capacidade Média de Processamento (CMP), que quantifica o quanto uma federação é mais potente que as demais. A partir 


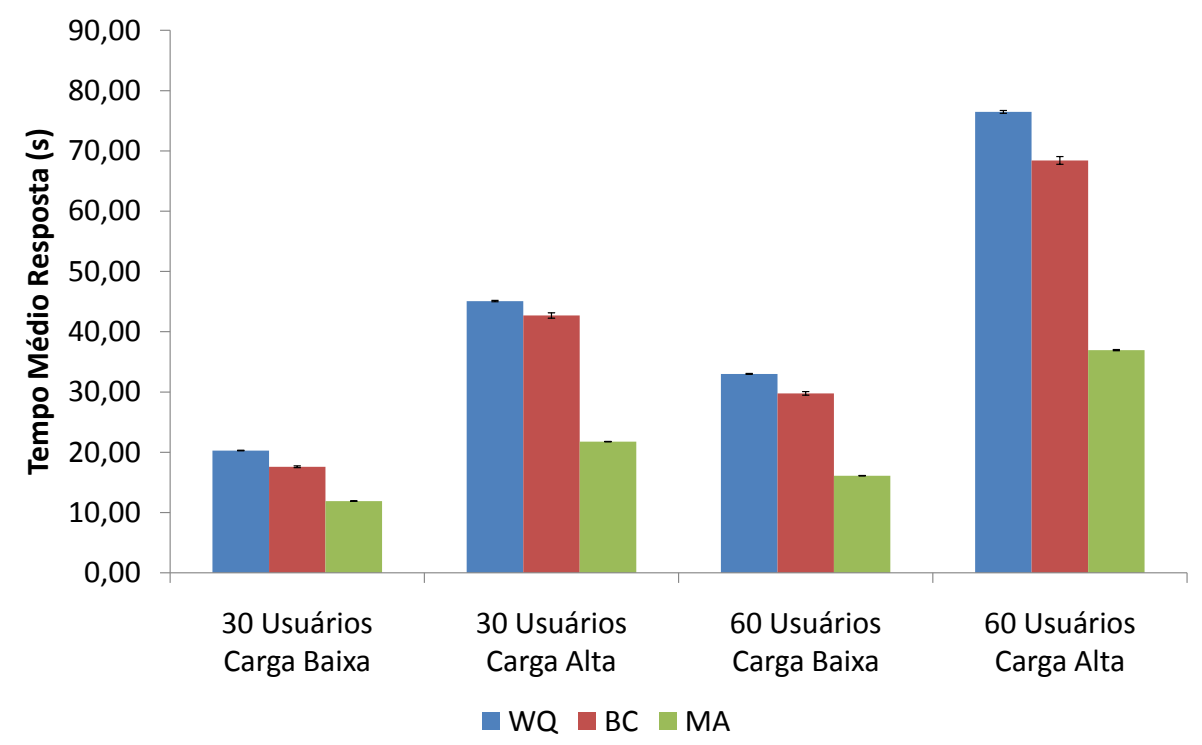

Figura 6.1: Tempo Médio de Resposta - 2 Federações.

Tabela 6.2: Tabelas com os Valores do Tempo Médio de Resposta em 2 Federações. Tabela 6.2.a: 30 Usuários - Carga Baixa.

Tabela 6.2.b: 30 Usuários - Carga Alta.

\begin{tabular}{|c|c|c|c|c|}
\hline Política & TMR & Inf & Sup & DP \\
\hline WQ & 20,29 & 20,24 & 20,34 & 2,58 \\
\hline BC & 17,59 & 17,45 & 17,74 & 7,24 \\
\hline MA & 11,89 & 11,85 & 11,93 & 2,02 \\
\hline
\end{tabular}

\begin{tabular}{|c|c|c|c|c|}
\hline Política & TMR & Inf & Sup & DP \\
\hline WQ & 45,09 & 44,97 & 45,20 & 5,80 \\
\hline BC & 42,69 & 42,25 & 43,13 & 22,18 \\
\hline MA & 21,76 & 21,72 & 21,80 & 2,12 \\
\hline
\end{tabular}

Tabela 6.2.c: 60 Usuários - Carga Baixa.

Tabela 6.2.d: 60 Usuários - Carga Alta.

\begin{tabular}{|c|c|c|c|c|}
\hline Política & TMR & Inf & Sup & DP \\
\hline WQ & 33,00 & 32,92 & 33,08 & 4,00 \\
\hline BC & 29,77 & 29,47 & 30,07 & 14,95 \\
\hline MA & 16,11 & 16,07 & 16,15 & 2,08 \\
\hline
\end{tabular}

\begin{tabular}{|c|c|c|c|c|}
\hline Política & TMR & Inf & Sup & DP \\
\hline WQ & 76,48 & 76,24 & 76,71 & 11,75 \\
\hline BC & 68,42 & 67,78 & 69,06 & 32,41 \\
\hline MA & 36,95 & 36,85 & 37,05 & 5,03 \\
\hline
\end{tabular}

da CMP, é determinado o número de aplicações que a federação mais potente receberá a mais que as outras federações, conforme apresentado na Tabela 5.8. No entanto, essa política proporciona um maior desbalanceamento de carga, pois aplicações do tipo Pesada e Muito Pesada podem ser submetidas para as federações com menor potência computacional, o que pode influenciar negativamente nas variáveis de resposta. Além disso, o número de aplicações que a federação mais potente irá receber a mais que as outras pode gerar uma sobrecarga sobre essa federação e ociosidade nas demais. Por exemplo, considere uma federação F1 que recebe três aplicações a mais que uma federação F2. O fato da política Baseada na Capacidade não analisar informações sobre as aplicações que são submetidas para execução influência diretamente nas variáveis de resposta. Isso porque podem ser submetidas três aplicações dos tipos Pesada e Muito Pesada para F1, enquanto que F2 pode receber uma aplicação do tipo Leve ou Média. Em um ambiente onde muitas aplicações são submetidas e considerando uma distribuição dessas aplicações como citada neste parágrafo, a federação F1 pode em algum momento da simulação estar sobrecarregada e F2 ociosa. 
Por fim, na política WQ nenhuma informação dos recursos ou das aplicações é utilizada durante o escalonamento. Assim, aplicações dos tipos Pesada ou Muito Pesada podem ser atribuídas a federações com baixa potência computacional, diminuindo o desempenho do sistema.

Cabe ressaltar que em todos os casos analisados, como pode ser observado nas Tabelas $6.2 \mathrm{e}$ 6.3 e nas Figuras 6.1 e 6.2, os intervalos de confiança obtidos são pequenos, permitindo concluir-se sobre a diferença entre as variáveis de resposta.

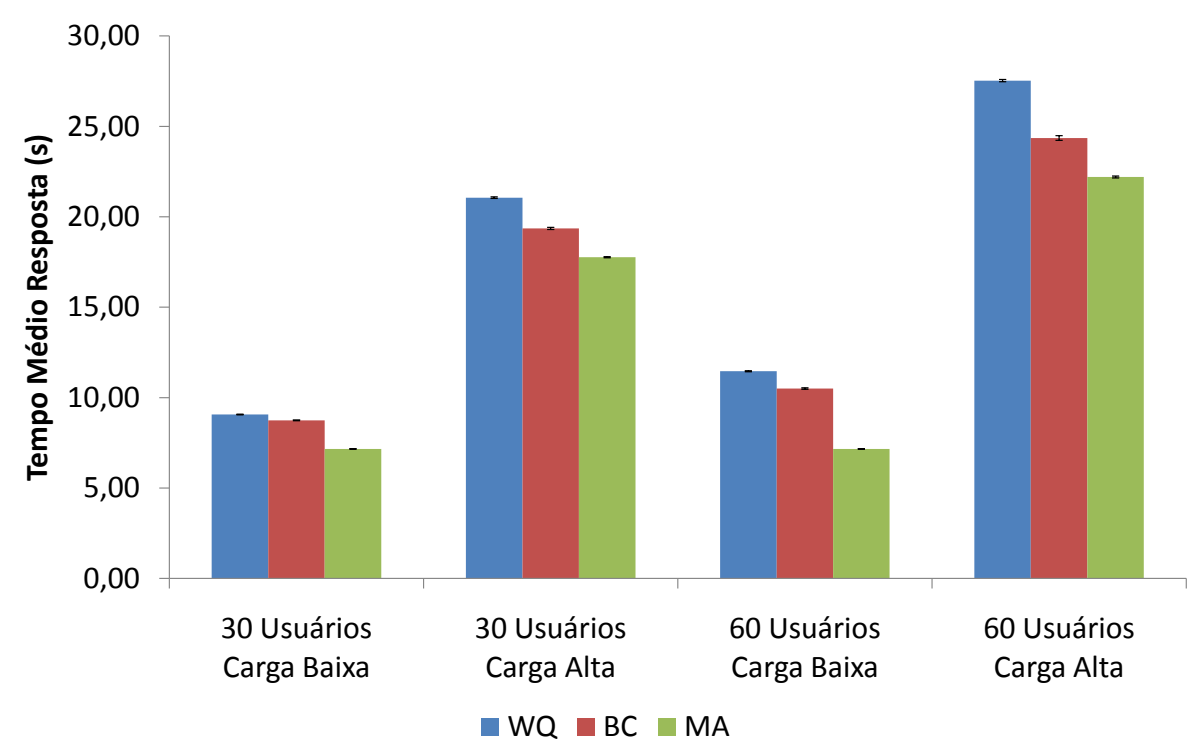

Figura 6.2: Tempo Médio de Resposta - 4 Federações.

Tabela 6.3: Tabelas com os Valores do Tempo Médio de Resposta em 4 Federações. Tabela 6.3.a: 30 Usuários - Carga Baixa.

\begin{tabular}{|c|c|c|c|c|}
\hline Política & TMR & Inf & Sup & DP \\
\hline WQ & 9,07 & 9,04 & 9,09 & 1,04 \\
\hline BC & 8,74 & 8,72 & 8,76 & 1,06 \\
\hline MA & 7,16 & 7,14 & 7,18 & 0,83 \\
\hline
\end{tabular}

Tabela 6.3.b: 30 Usuários - Carga Alta.

Tabela 6.3.c: 60 Usuários - Carga Baixa.

\begin{tabular}{|c|c|c|c|c|}
\hline Política & TMR & Inf & Sup & DP \\
\hline WQ & 21,06 & 21,01 & 21,10 & 2,15 \\
\hline BC & 19,36 & 19,30 & 19,42 & 3,02 \\
\hline MA & 17,76 & 17,73 & 17,80 & 1,61 \\
\hline
\end{tabular}

\begin{tabular}{|c|c|c|c|c|}
\hline Política & TMR & Inf & Sup & DP \\
\hline WQ & 11,46 & 11,43 & 11,49 & 1,44 \\
\hline BC & 10,50 & 10,46 & 10,54 & 2,03 \\
\hline MA & 7,16 & 7,15 & 7,18 & 0,82 \\
\hline
\end{tabular}

Tabela 6.3.d: 60 Usuários - Carga Alta.

\begin{tabular}{|c|c|c|c|c|}
\hline Política & TMR & Inf & Sup & DP \\
\hline WQ & 27,53 & 27,47 & 27,59 & 3,16 \\
\hline BC & 24,36 & 24,23 & 24,49 & 6,52 \\
\hline MA & 22,20 & 22,15 & 22,25 & 2,75 \\
\hline
\end{tabular}

Analisando um ambiente composto por duas federações e com trinta usuários (Figura 6.1), verifica-se que o aumento de $100 \%$ da carga Baixa para a Alta proporciona um aumento no Tempo Médio de Resposta que varia entre $45 \%$ e 59\%. Para sessenta usuários esse aumento é de aproximadamente $56 \%$. Com a utilização de quatro federações (Figura 6.2) esse aumento tem uma variação entre $55 \%$ e $60 \%$ para 30 usuários e entre 57\% e $68 \%$ para 60 usuários.

Aumentando-se o número de usuários, de trinta para sessenta, tem-se um aumento no Tempo Médio de Resposta que varia entre $26 \%$ e $41 \%$ na execução de aplicações de carga Baixa em duas federações. Esse aumento é de aproximadamente $40 \%$ quando é considerado o mesmo número 
de federações e a execução de aplicações de carga Alta. Em um ambiente com quatro federações tem-se um aumento reduzido do Tempo Médio de Resposta que varia entre $0 \%$ e $21 \%$ na execução de aplicações de carga Baixa e de aproximadamente $21 \%$ na execução de aplicações de carga Alta.

Por último, alterando-se o número de federações de duas para quatro, tem-se uma redução do Tempo Médio de Resposta variando entre $40 \%$ e 55\% em um ambiente com trinta usuários executando aplicações de carga Baixa. Em uma carga Alta essa redução varia entre $18 \%$ e $55 \%$. Para sessenta usuários e aplicações de carga Baixa tem-se uma redução variando entre $55 \%$ e $65 \%$, enquanto que para uma carga Alta, tem-se uma variação de $40 \%$ e $64 \%$.

\subsection{Throughput Médio}

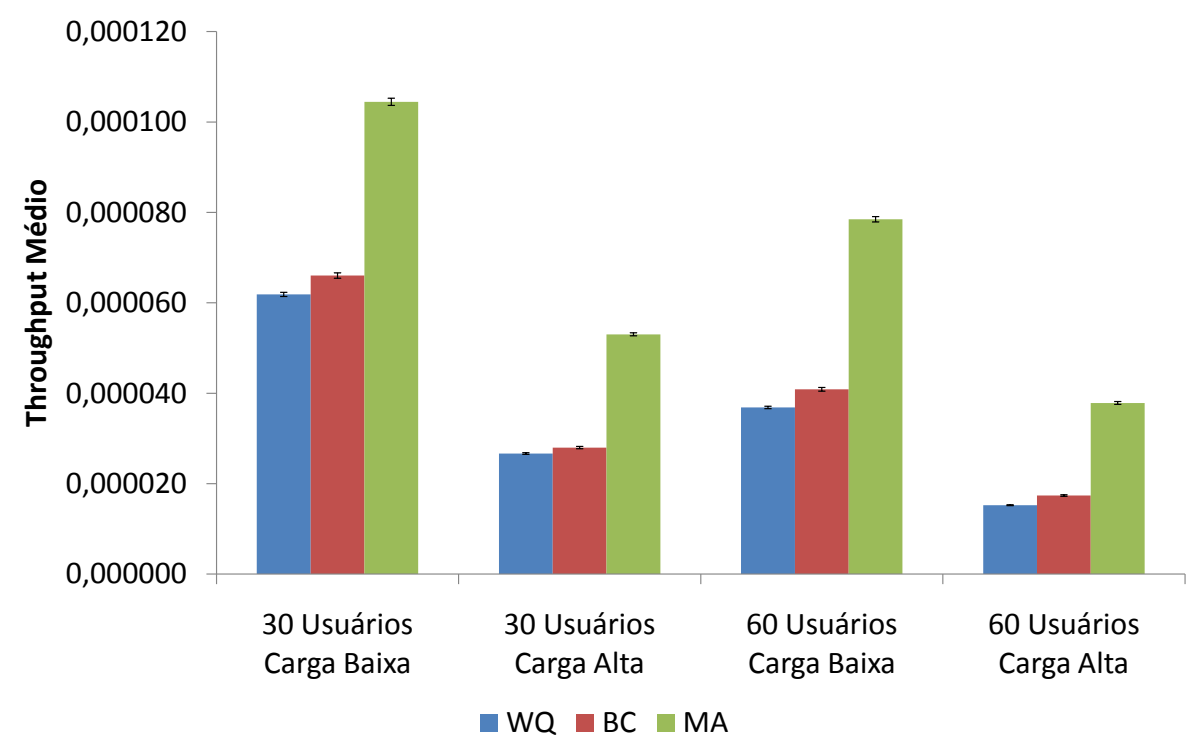

Figura 6.3: Throughput Médio - 2 Federações.

Tabela 6.4: Tabelas com os Valores do Throughput Médio em 2 Federações.

Tabela 6.4.a: 30 Usuários - Carga Baixa.

Tabela 6.4.b: 30 Usuários - Carga Alta.

\begin{tabular}{|c|c|c|c|c|}
\hline Política & TM & Inf & Sup & DP \\
\hline WQ & 0,000062 & 0,000061 & 0,000062 & 0,000023 \\
\hline BC & 0,000066 & 0,000065 & 0,000067 & 0,000030 \\
\hline MA & 0,000104 & 0,000104 & 0,000105 & 0,000040 \\
\hline
\end{tabular}

\begin{tabular}{|c|c|c|c|c|}
\hline Política & TM & Inf & Sup & DP \\
\hline WQ & 0,000027 & 0,000026 & 0,000027 & 0,000009 \\
\hline BC & 0,000028 & 0,000028 & 0,000028 & 0,000013 \\
\hline MA & 0,000053 & 0,000053 & 0,000053 & 0,000017 \\
\hline
\end{tabular}

Tabela 6.4.c: 60 Usuários - Carga Baixa.

Tabela 6.4.d: 60 Usuários - Carga Alta.

\begin{tabular}{|c|c|c|c|c|}
\hline Política & TM & Inf & Sup & DP \\
\hline WQ & 0,000037 & 0,000037 & 0,000037 & 0,000014 \\
\hline BC & 0,000041 & 0,000040 & 0,000041 & 0,000021 \\
\hline MA & 0,000078 & 0,000078 & 0,000079 & 0,000030 \\
\hline
\end{tabular}

\begin{tabular}{|c|c|c|c|c|}
\hline Política & TM & Inf & Sup & DP \\
\hline WQ & 0,000015 & 0,000015 & 0,000015 & 0,000005 \\
\hline BC & 0,000017 & 0,000017 & 0,000018 & 0,000009 \\
\hline MA & 0,000038 & 0,000038 & 0,000038 & 0,000016 \\
\hline
\end{tabular}

Na Figura 6.3, considerando-se um ambiente com duas federações e o aumento de $100 \%$ do número de clientes, verifica-se que a redução no Throughput Médio não mantém a mesma proporção. Tem-se uma redução no Throughput Médio variando entre $25 \%$ e $40 \%$ na execução de 
aplicações de carga Baixa. Na execução de aplicações de carga Alta tem-se uma redução variando entre $28 \%$ e $45 \%$. Com a utilização de quatro federações, apresentada na Figura 6.4, observa-se que a variação é menor, entre $0 \%$ e $17 \%$.

Analisando o aumento de $100 \%$ no número de federações, ou seja de duas para quatro, verificase que o Throughput Médio é maior na Figura 6.4 quando comparada com a Figura 6.3. Na Figura 6.4 tem-se um aumento no Throughput Médio que varia entre 38\% e 53\% na execução de aplicações de carga Baixa de 30 usuários. Para 60 usuários essa alteração no número de federações implicou em um aumento que varia entre $53 \%$ e $66 \%$. Em aplicações de carga Alta, o aumento de $100 \%$ das federações causou um aumento no Throughput Médio variando entre $22 \%$ e $53 \%$ com 30 usuários, e entre $32 \%$ e $67 \%$ para 60 usuários.

Com isso, observa-se que o aumento do número de federações aumenta o Throughput Médio, pois tem-se mais recursos disponíveis para a execução das aplicações. No entanto, a proporção de aumento não é mantida. Por outro lado, o aumento no número de clientes reduz o Throughput Médio, pois a sobrecarga no sistema é maior.

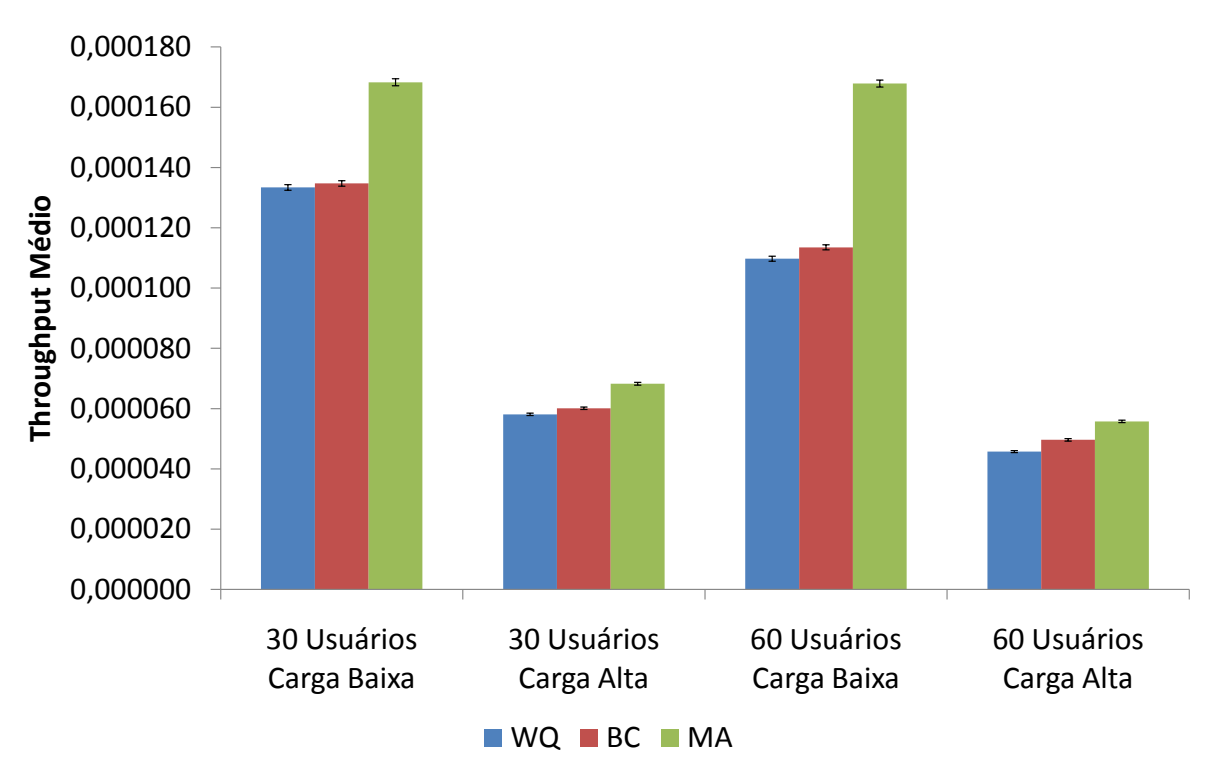

Figura 6.4: Throughput Médio - 4 Federações.

Tabela 6.5: Tabelas com os Valores do Throughput Médio em 4 Federações.

Tabela 6.5.a: 30 Usuários - Carga Baixa.

\begin{tabular}{|c|c|c|c|c|}
\hline Política & TM & Inf & Sup & DP \\
\hline WQ & 0,000133 & 0,000132 & 0,000134 & 0,000047 \\
\hline BC & 0,000135 & 0,000134 & 0,000136 & 0,000045 \\
\hline MA & 0,000168 & 0,000167 & 0,000169 & 0,000059 \\
\hline
\end{tabular}

Tabela 6.5.c: 60 Usuários - Carga Baixa.

\begin{tabular}{|c|c|c|c|c|}
\hline Política & TM & Inf & Sup & DP \\
\hline WQ & 0,000110 & 0,000109 & 0,000111 & 0,000042 \\
\hline BC & 0,000114 & 0,000113 & 0,000114 & 0,000042 \\
\hline MA & 0,000168 & 0,000167 & 0,000169 & 0,000058 \\
\hline
\end{tabular}

Tabela 6.5.b: 30 Usuários - Carga Alta.

\begin{tabular}{|c|c|c|c|c|}
\hline Política & TM & Inf & Sup & DP \\
\hline WQ & 0,000058 & 0,000058 & 0,000059 & 0,000020 \\
\hline BC & 0,000060 & 0,000060 & 0,000061 & 0,000021 \\
\hline MA & 0,000068 & 0,000068 & 0,000069 & 0,000023 \\
\hline
\end{tabular}

Tabela 6.5.d: 60 Usuários - Carga Alta.

\begin{tabular}{|c|c|c|c|c|}
\hline Política & TM & Inf & Sup & DP \\
\hline WQ & 0,000046 & 0,000045 & 0,000046 & 0,000017 \\
\hline BC & 0,000050 & 0,000049 & 0,000050 & 0,000021 \\
\hline MA & 0,000056 & 0,000055 & 0,000056 & 0,000021 \\
\hline
\end{tabular}


As tabelas apresentadas nas Tabelas 6.4 e 6.5 e nas Figuras 6.3 e 6.4 mostram os limites inferiores e superiores que compõem o intervalo de confiança de cada experimento. Em todos os casos analisados tem-se que os intervalos de confiança não se sobrepõem, permitindo afirmar que os resultados são estatisticamente diferentes. O único experimento em que isso não ocorre é quando considera-se 30 usuários e carga Baixa, apresentado na Tabela 6.5.a, onde observa-se que o limite superior da política WorkQueue e o limite inferior da política Baseada na Capacidade possuem o mesmo valor.

\subsection{Influência dos Fatores}

Pelo fato do fator Política (B) possuir três níveis, foi realizada uma análise combinando os níveis em 2 a 2 para determinar a influência de cada fator sobre as variáveis de resposta. Assim foram determinadas as influências dos fatores obedecendo às combinações: WQ x BC, WQ x MA e BC x MA. Através dessas combinações foi possível determinar um arranjo de 24 experimentos, que é o número de níveis elevado ao número de fatores.

Utilizando o modelo de regressão (Jain, 1991) foram calculadas as influências dos fatores e suas interações para cada combinação feita 2 a 2 dos níveis do fator Política.

\subsubsection{WorkQueue vs Baseada na Capacidade}

Na Figura 6.5 é apresentado um gráfico em pizza com as influências dos fatores sobre a variável de resposta Tempo Médio de Resposta.

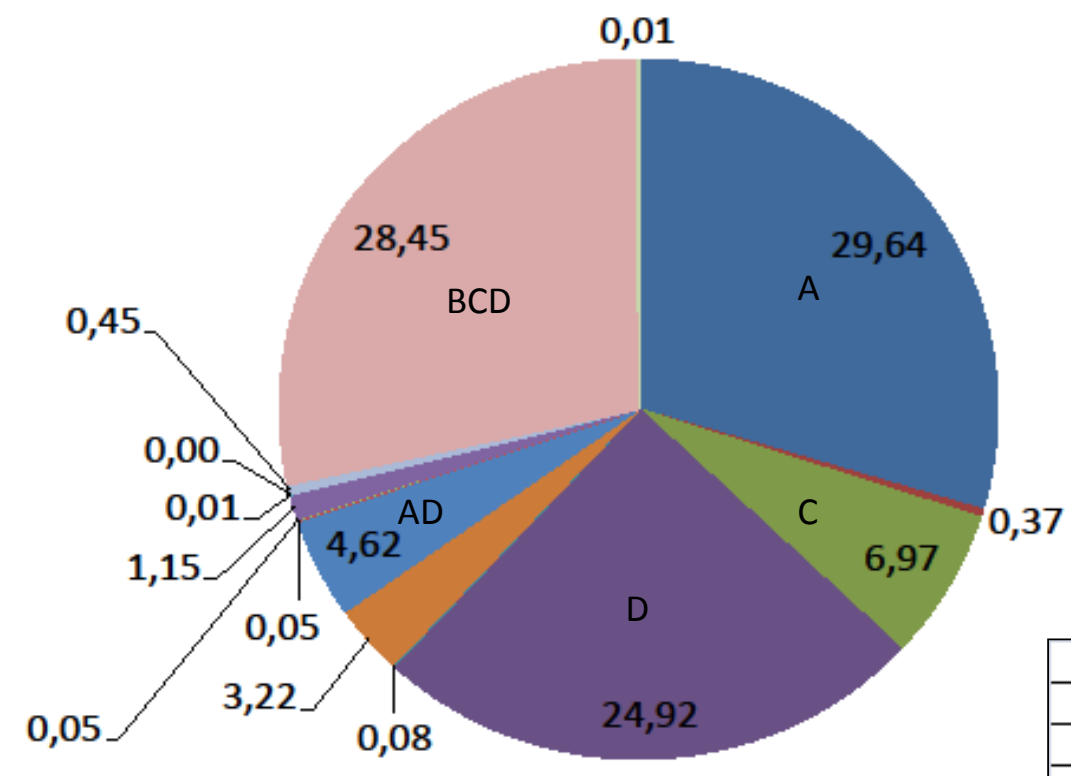

\begin{tabular}{|c|c|}
\hline A & $N^{0}$ Federaç̃oses \\
\hline B & Política \\
\hline C & $N^{0}$ Usuários \\
\hline D & Carga \\
\hline
\end{tabular}

$\square \mathrm{A} \square \mathrm{B} \square \mathrm{C} \square \mathrm{D} \square \mathrm{AB} \square \mathrm{AC} \square \mathrm{AD} \square \mathrm{BC} \square \mathrm{BD} \square \mathrm{CD} \square \mathrm{ABC} \square \mathrm{ABD} \square \mathrm{ACD} \square \mathrm{BCD} \square \mathrm{ABCD}$

Figura 6.5: Influência dos Fatores sobre o Tempo Médio de Resposta - Combinação WQ x BC. 
Analisando os experimentos com combinação 2 a 2 dos níveis do fator Política (B), observa-se que na combinação WQ x BC, o fator Número de Federações (A) foi o que mais influenciou sobre a variável de resposta Tempo Médio de Resposta com 29,64\% (Figura 6.5). Aumentando o número de federações, tem-se uma quantidade maior de recursos disponíveis para receberem as aplicações e, conseqüentemente, menor tempo de execução total.

A segunda maior influência foi da combinação dos fatores Política (B), Número de Usuários (C) e Carga (D) com 28,45\% de influência. O aumento do número de usuários proporciona uma disputa maior por recursos computacionais. Esses usuários enviam aplicações para serem executadas, as quais, quanto mais exorbitantes forem, proporcionam uma maior sobrecarga imposta ao ambiente. Com isso, o aumento do número de usuários e da carga das aplicações submetidas por eles, exige uma política de escalonamento eficiente, pois se essas aplicações não forem corretamente distribuídas, o tempo de execução final pode não ser satisfatório.

Em terceiro, tem-se o fator Carga (D) com 24,92\% de influência. Como dito anteriormente, quanto maior a carga imposta ao sistema, maior será o tempo gasto para concluir a sua execução.

Nessa combinação percebe-se que o fator Política (B), quando analisado sem nenhuma interação quase não influenciou, apenas $0,37 \%$. A influência de todos os fatores e suas combinações sobre as variáveis de resposta Tempo Médio de Resposta e Throughput Médio é apresentada na Tabela 6.6.

Tabela 6.6: Influência dos Fatores - WQ x BC.

\begin{tabular}{|c|c|c|}
\hline & Tempo Médio Resposta & Throughput Médio \\
\hline A & 29,64 & 45,14 \\
\hline B & 0,37 & 0,14 \\
\hline C & 6,97 & 5,11 \\
\hline D & 24,92 & 41,71 \\
\hline AB & 0,08 & 0,00 \\
\hline AC & 3,22 & 0,01 \\
\hline AD & 4,62 & 6,69 \\
\hline BC & 0,05 & 0,01 \\
\hline BD & 0,05 & 0,01 \\
\hline CD & 1,15 & 0,64 \\
\hline ABC & 0,01 & 0,00 \\
\hline ABD & 0,00 & 0,01 \\
\hline ACD & 0,45 & 0,01 \\
\hline BCD & 28,45 & 0,54 \\
\hline ABCD & 0,01 & 0,00 \\
\hline
\end{tabular}

A Figura 6.6 apresenta um gráfico em pizza com as influências dos fatores sobre a variável de resposta Throughput Médio. Quando a variável de resposta Throughput Médio é analisada, observa-se que o fator Número de Federações (A) foi o que mais influenciou com 45,14\%. Isto porque, quanto maior for o número de recursos disponíveis, maior será o número de aplicações que serão submetidas para execução e com isso, maior será o Throughput Médio. Em seguida tem-se o fator Carga (D) com 41,71\%, pois quanto maior a carga, maior será o tempo gasto na execução e, conseqüentemente, menor será o throughput. 


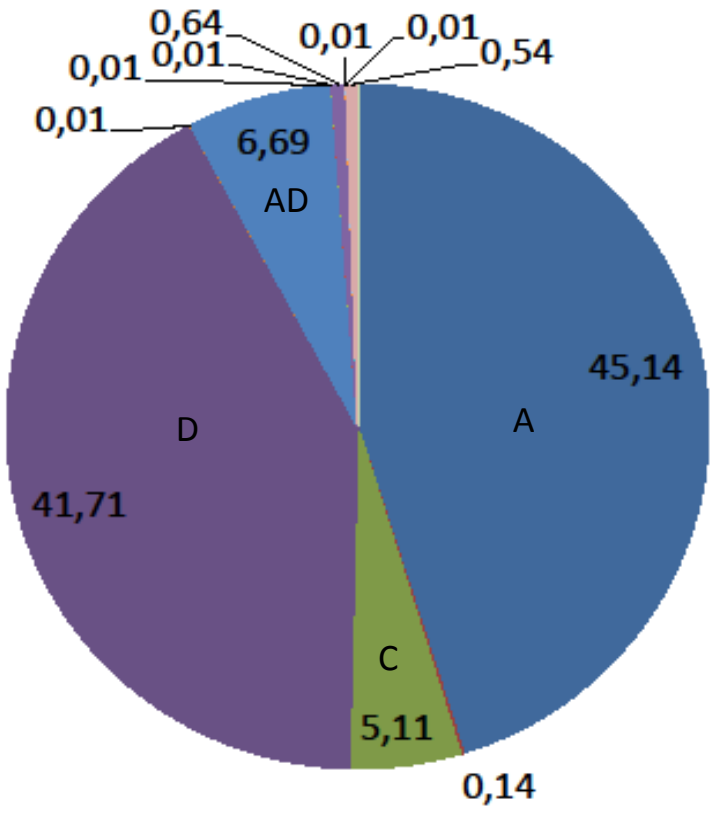

\begin{tabular}{|c|c|}
\hline A & No Federações \\
\hline B & Politica \\
\hline C & No Usuários $^{\circ}$ \\
\hline D & Carga \\
\hline
\end{tabular}

$\square \mathrm{A} \square \mathrm{B} \square \mathrm{C} \square \mathrm{D} \square \mathrm{AB} \square \mathrm{AC} \square \mathrm{AD} \square \mathrm{BC} \square \mathrm{BD} \square \mathrm{CD} \square \mathrm{ABC} \square \mathrm{ABD} \square \mathrm{ACD} \square \mathrm{BCD} \square \mathrm{ABCD}$

Figura 6.6: Influência dos Fatores sobre o Throughput Médio - Combinação WQ x BC.

\subsubsection{WorkQueue vs Melhor Arranjo}

Na Figura 6.7 é apresentado um gráfico em pizza com as influências dos fatores sobre a variável de resposta Tempo Médio de Resposta.

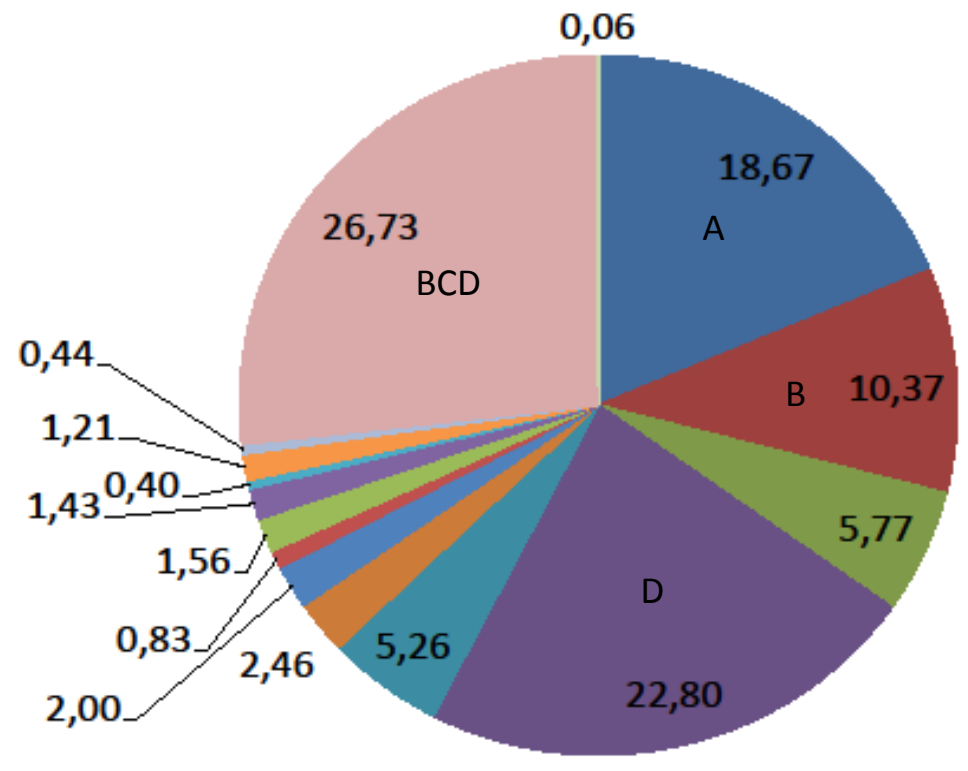

\begin{tabular}{|c|c|}
\hline A & No Federaç̃oes \\
\hline B & Política \\
\hline C & $N^{\circ}$ Usuários \\
\hline D & Carga \\
\hline
\end{tabular}

$\square \mathrm{A} \square \mathrm{B} \square \mathrm{C} \square \mathrm{D} \square \mathrm{AB} \square \mathrm{AC} \square \mathrm{AD} \square \mathrm{BC} \square \mathrm{BD} \square \mathrm{CD} \square \mathrm{ABC} \square \mathrm{ABD} \square \mathrm{ACD} \square \mathrm{BCD} \square \mathrm{ABCD}$

Figura 6.7: Influência dos Fatores sobre o Tempo Médio de Resposta - Combinação WQ x MA. 
Analisando os experimentos com combinação 2 a 2 dos níveis do fator Política (B), observase que na combinação WQ x MA, a variável de resposta Tempo Médio de Resposta (Figura 6.7) foi mais influenciada pela combinação dos fatores Política (B), Número de Usuários (C) e Carga (D), com 26,73\%, seguida pelo fator Carga (D) com 22,80\% e pelo fator Número de Federações com 18,67\%. Nota-se que na combinação anterior, o fator Número de Federações foi o que mais influenciou, enquanto que nessa, ele aparece em terceiro entre os que mais influenciaram. Além disso, nessa combinação tem-se que o fator Política teve maior influência nos resultados obtidos, $10,37 \%$, do que na combinação WQ x BC, com $0,37 \%$.

A influência de todos os fatores e suas combinações sobre as variáveis de resposta Tempo Médio de Resposta e Throughput Médio é apresentada na Tabela 6.7.

Tabela 6.7: Influência dos Fatores - WQ x MA.

\begin{tabular}{|c|c|c|}
\hline & Tempo Médio Resposta & Throughput Médio \\
\hline A & 18,67 & 28,25 \\
\hline B & 10,37 & 10,98 \\
\hline C & 5,77 & 2,86 \\
\hline D & 22,80 & 45,55 \\
\hline AB & 5,26 & 0,07 \\
\hline AC & 2,46 & 0,18 \\
\hline AD & 2,00 & 7,54 \\
\hline BC & 0,83 & 0,07 \\
\hline BD & 1,56 & 2,09 \\
\hline CD & 1,43 & 0,10 \\
\hline ABC & 0,40 & 0,13 \\
\hline ABD & 1,21 & 0,28 \\
\hline ACD & 0,44 & 0,11 \\
\hline BCD & 26,73 & 1,72 \\
\hline ABCD & 0,06 & 0,08 \\
\hline
\end{tabular}

Quando a variável de resposta Throughput Médio é analisada, observa-se que na combinação WQ x MA, o fator Carga (D) foi o que mais influenciou com 45,55\%, seguido pelo fator Federações (A) com $28,25 \%$ e pelo fator Política com 10,98\%.

A Figura 6.8 apresenta um gráfico em pizza com as influências dos fatores sobre a variável de resposta Throughput Médio. 


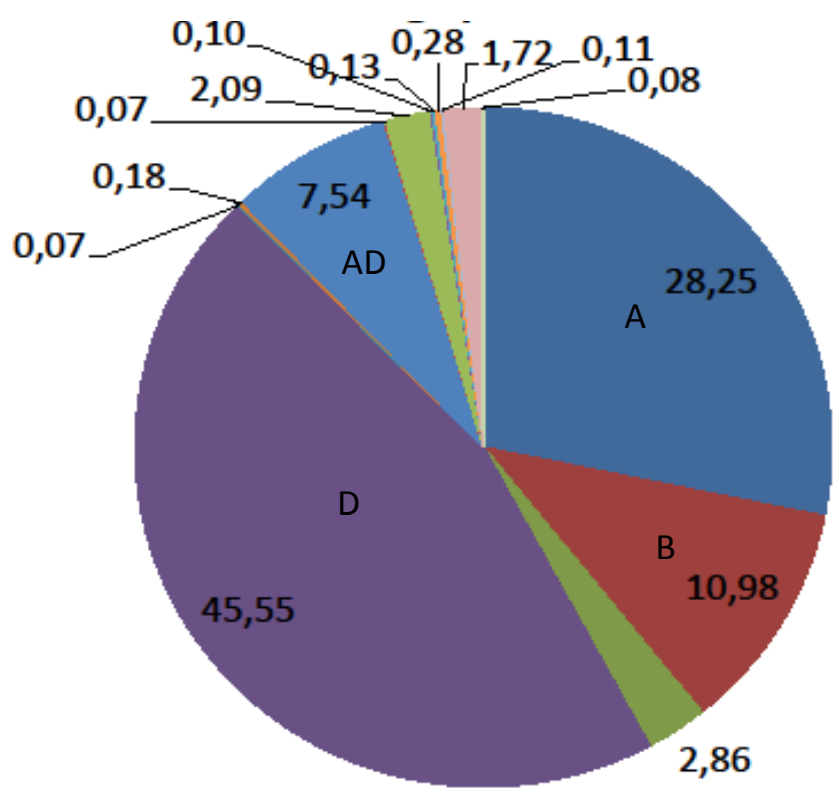

\begin{tabular}{|c|c|}
\hline A & $N^{0}$ Federações \\
\hline B & Politica \\
\hline C & No Usuários $^{\text {Carga }}$ \\
\hline D & Cara \\
\hline
\end{tabular}

$\square \mathrm{A} \square \mathrm{B} \square \mathrm{C} \square \mathrm{D} \square \mathrm{AB} \square \mathrm{AC} \square \mathrm{AD} \square \mathrm{BC} \square \mathrm{BD} \square \mathrm{CD} \square \mathrm{ABC} \square \mathrm{ABD} \square \mathrm{ACD} \square \mathrm{BCD} \square \mathrm{ABCD}$

Figura 6.8: Influência dos Fatores sobre o Throughput Médio - Combinação WQ x MA.

\subsubsection{Baseada na Capacidade vs Melhor Arranjo}

Na Figura 6.9 é apresentado um gráfico em pizza com as influências dos fatores sobre a variável de resposta Tempo Médio de Resposta.

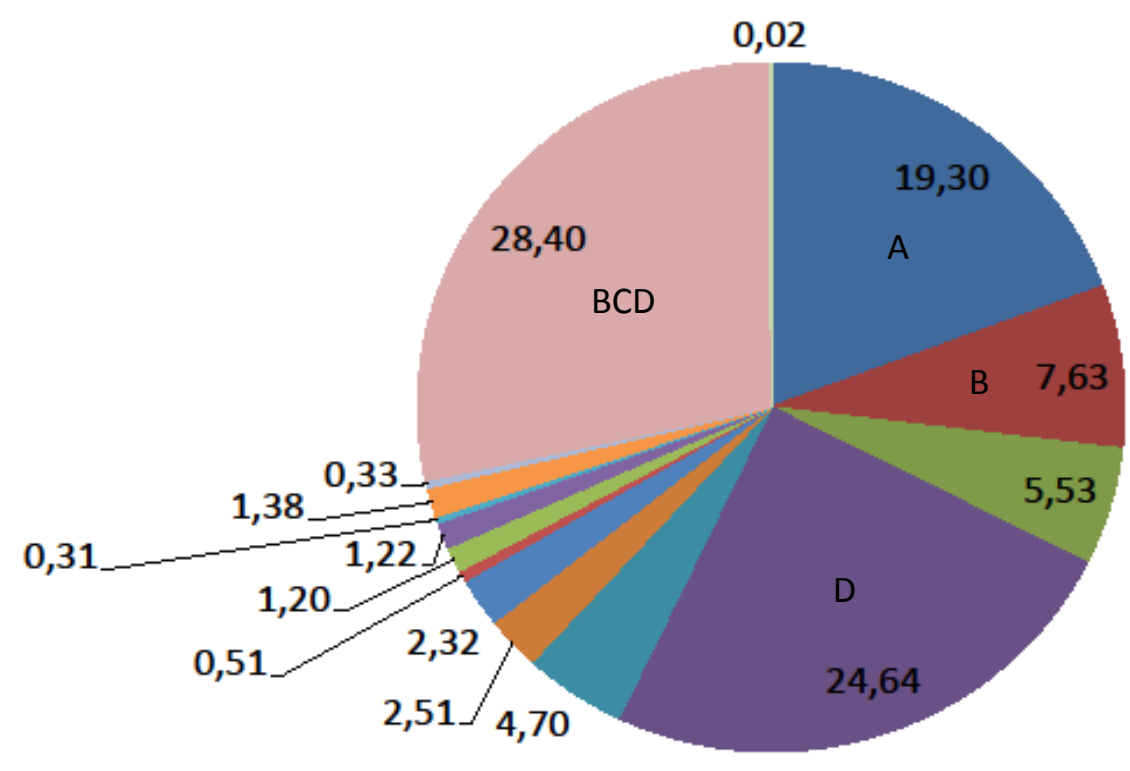

\begin{tabular}{|c|c|}
\hline A & No Federações \\
\hline B & Política \\
\hline C & No Usuários $^{\text {Carga }}$ \\
\hline D & Car \\
\hline
\end{tabular}

$\square \mathrm{A} \square \mathrm{B} \square \mathrm{C} \square \mathrm{D} \square \mathrm{AB} \square \mathrm{AC} \square \mathrm{AD} \square \mathrm{BC} \square \mathrm{BD} \square \mathrm{CD} \square \mathrm{ABC} \square \mathrm{ABD} \square \mathrm{ACD} \square \mathrm{BCD} \square \mathrm{ABCD}$

Figura 6.9: Influência dos Fatores sobre o Tempo Médio de Resposta - Combinação BC x MA. 
Nos experimentos com combinação 2 a 2 dos níveis do fator Política (B), observa-se que na combinação BC x MA, a variável de resposta Tempo Médio de Resposta, a exemplo do que aconteceu na combinação WQ x MA, também foi mais influenciada pela combinação dos fatores Política (B), Usuários (C) e Carga (D) com 28,40\%, seguida pelo fator Carga (D) com 24,64\% e pelo fator Número de Federações com 19,30\%.

A influência de todos os fatores e suas combinações sobre as variáveis de resposta Tempo Médio de Resposta e Throughput Médio é apresentada na Tabela 6.8.

Tabela 6.8: Influência dos Fatores - BC x MA.

\begin{tabular}{|c|c|c|}
\hline & Tempo Médio Resposta & Throughput Médio \\
\hline A & 19,30 & 28,89 \\
\hline B & 7,63 & 9,17 \\
\hline C & 5,53 & 2,68 \\
\hline D & 24,64 & 47,28 \\
\hline AB & 4,70 & 0,07 \\
\hline AC & 2,51 & 0,22 \\
\hline AD & 2,32 & 7,30 \\
\hline BC & 0,51 & 0,04 \\
\hline BD & 1,20 & 1,94 \\
\hline CD & 1,22 & 0,11 \\
\hline ABC & 0,31 & 0,11 \\
\hline ABD & 1,38 & 0,36 \\
\hline ACD & 0,33 & 0,13 \\
\hline BCD & 28,40 & 1,64 \\
\hline ABCD & 0,02 & 0,07 \\
\hline
\end{tabular}

Quando a variável de resposta Throughput Médio é analisada, observa-se o mesmo comportamento apresentado na Seção anterior para a combinação BC x MA, onde o fator Carga (D) foi o que mais influenciou com 47,28\%, seguido pelo fator Número de Federações (A) com 28,89\% e pelo fator Política com $9,17 \%$.

A Figura 6.10 apresenta um gráfico em pizza com as influências dos fatores sobre a variável de resposta Throughput Médio. 


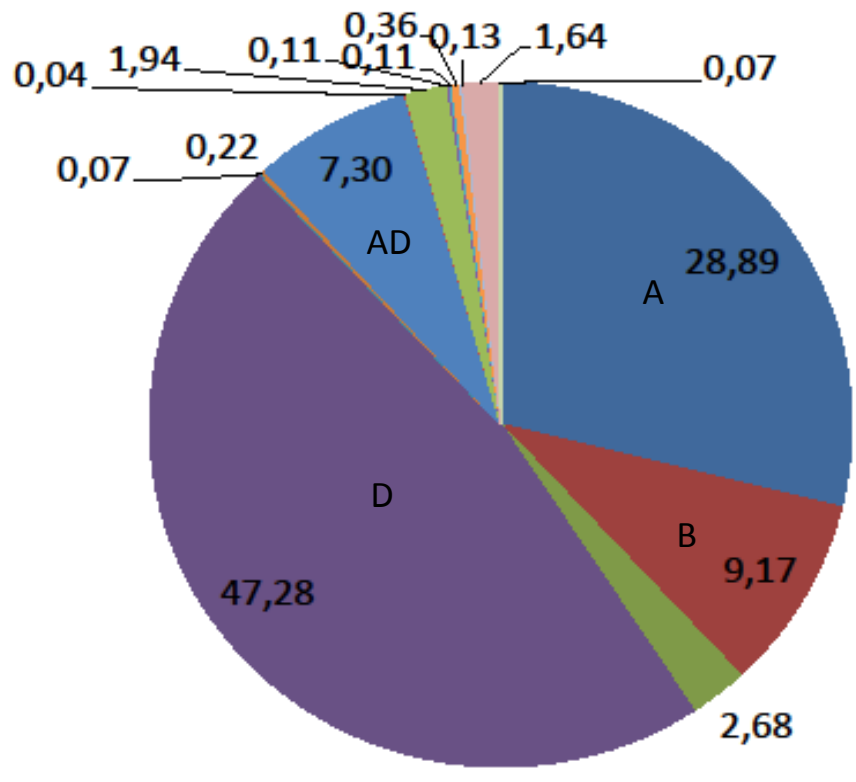

\begin{tabular}{|c|c|}
\hline A & $N^{0}$ Federações \\
\hline B & Politica \\
\hline C & $N^{0}$ Usuários \\
\hline D & Carga \\
\hline
\end{tabular}

$\square \mathrm{A} \square \mathrm{B} \square \mathrm{C} \square \mathrm{D} \square \mathrm{AB} \square \mathrm{AC} \square \mathrm{AD} \square \mathrm{BC} \square \mathrm{BD} \square \mathrm{CD} \square \mathrm{ABC} \square \mathrm{ABD} \square \mathrm{ACD} \square \mathrm{BCD} \square \mathrm{ABCD}$

Figura 6.10: Influência dos Fatores sobre o Throughput Médio - Combinação BC x MA.

\subsection{Conclusões Parciais}

Com a análise dos experimentos e dos resultados obtidos conclui-se que:

- Quanto maior o número de federações, maior é o número de recursos disponíveis para a execução das aplicações e conseqüentemente, menor é o Tempo Médio de Resposta conforme mostrado nos gráficos das Figuras 6.11, 6.12 e 6.13.

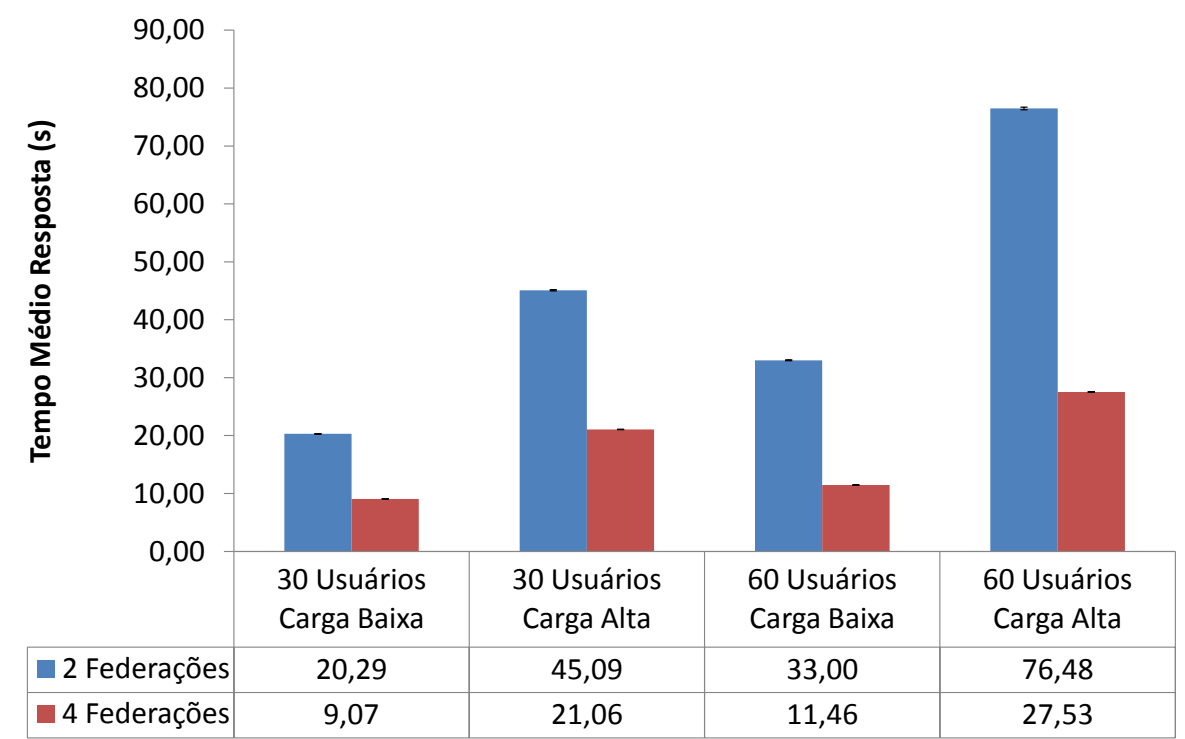

Figura 6.11: Tempo Médio de Resposta - Política WQ. 
Na Figura 6.11, com o aumento de $100 \%$ do número de federações, verifica-se uma redução no Tempo Médio de Resposta de 55\% para um ambiente com trinta usuários executando aplicações de carga Baixa. Essa redução é similar quando considera-se aplicações de carga Alta, 53\%. No entanto, com sessenta usuários tem-se uma maior redução no Tempo Médio de Resposta, de 65\% para carga Baixa e de $64 \%$ para carga Alta.

Por outro lado, o aumento da carga Baixa para carga Alta proporciona o aumento do Tempo Médio de Resposta de 55\% em um ambiente com trinta usuários e duas federações. Esse aumento é similar em um ambiente com sessenta usuários e duas federações, de 57\%, e em um ambiente com trinta e sessenta usuários e quatro federações, $57 \%$ e $58 \%$, respectivamente.

Além disso, com o aumento de $100 \%$ do número de usuários tem-se uma elevação no Tempo Médio de Resposta de 38\% em um ambiente com duas federações e aplicações de carga Baixa. Com aplicações de carga Alta essa elevação é pouco superior, de $41 \%$. Com a utilização de quatro federações essa elevação é inferior, de $21 \%$ para um ambiente com carga Baixa e de $22 \%$ para um ambiente com carga Alta.

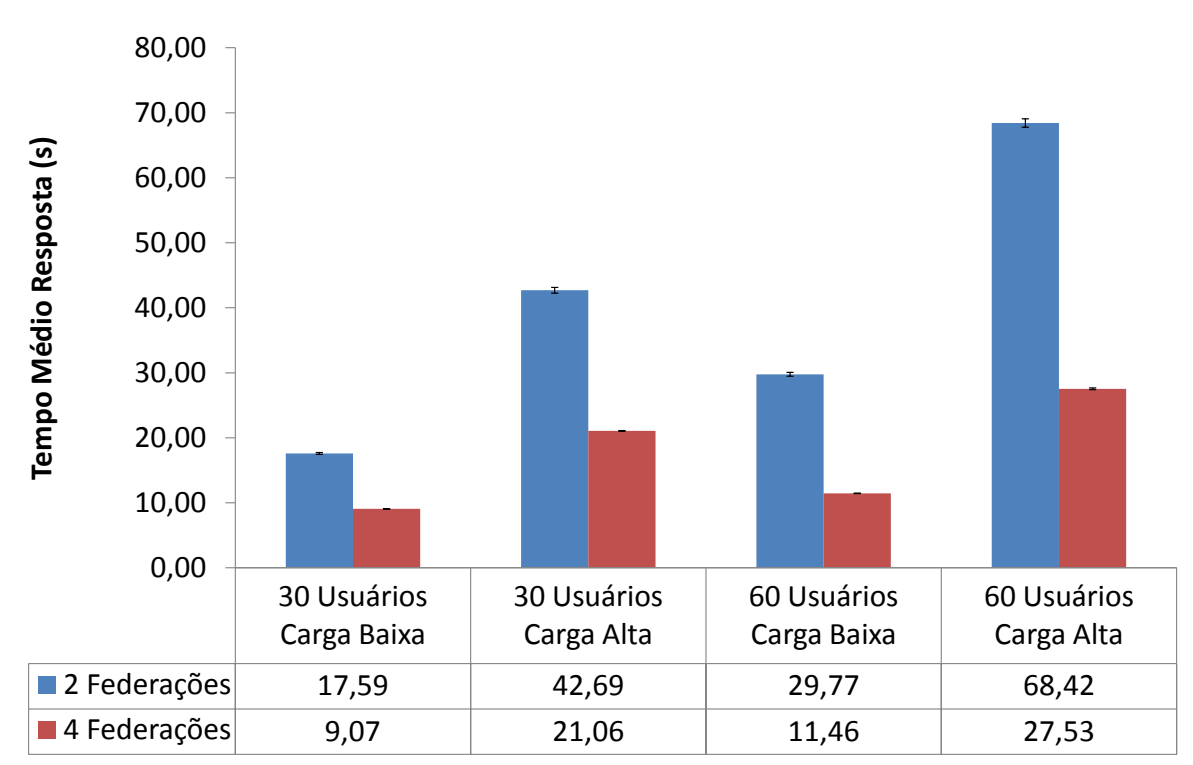

Figura 6.12: Tempo Médio de Resposta - Política BC.

Na Figura 6.12, com o aumento de $100 \%$ do número de federações, verifica-se uma redução no Tempo Médio de Resposta de 48\% para um ambiente com trinta usuários executando aplicações de carga Baixa. Essa redução é pouco superior com aplicações de carga Alta, 51\%. No entanto, com sessenta usuários tem-se uma maior redução no Tempo Médio de Resposta, de $61 \%$ para carga Baixa e de $60 \%$ para carga Alta.

Por outro lado, o aumento da carga Baixa para carga Alta proporciona o aumento do Tempo Médio de Resposta de 59\% em um ambiente com trinta usuários e duas federações. Esse aumento é pouco inferior em um ambiente com sessenta usuários e duas federações, de $56 \%$, e em um ambiente com trinta e sessenta usuários e quatro federações, $57 \%$ e $58 \%$, respectivamente. 
Além disso, com o aumento de $100 \%$ do número de usuários tem-se uma elevação no Tempo Médio de Resposta de $41 \%$ em um ambiente com duas federações e aplicações de carga Baixa. Com aplicações de carga Alta essa elevação é pouco inferior, de 38\%. Com a utilização de quatro federações essa elevação é inferior, de $21 \%$ para um ambiente com carga Baixa e de $23 \%$ para um ambiente com carga Alta.

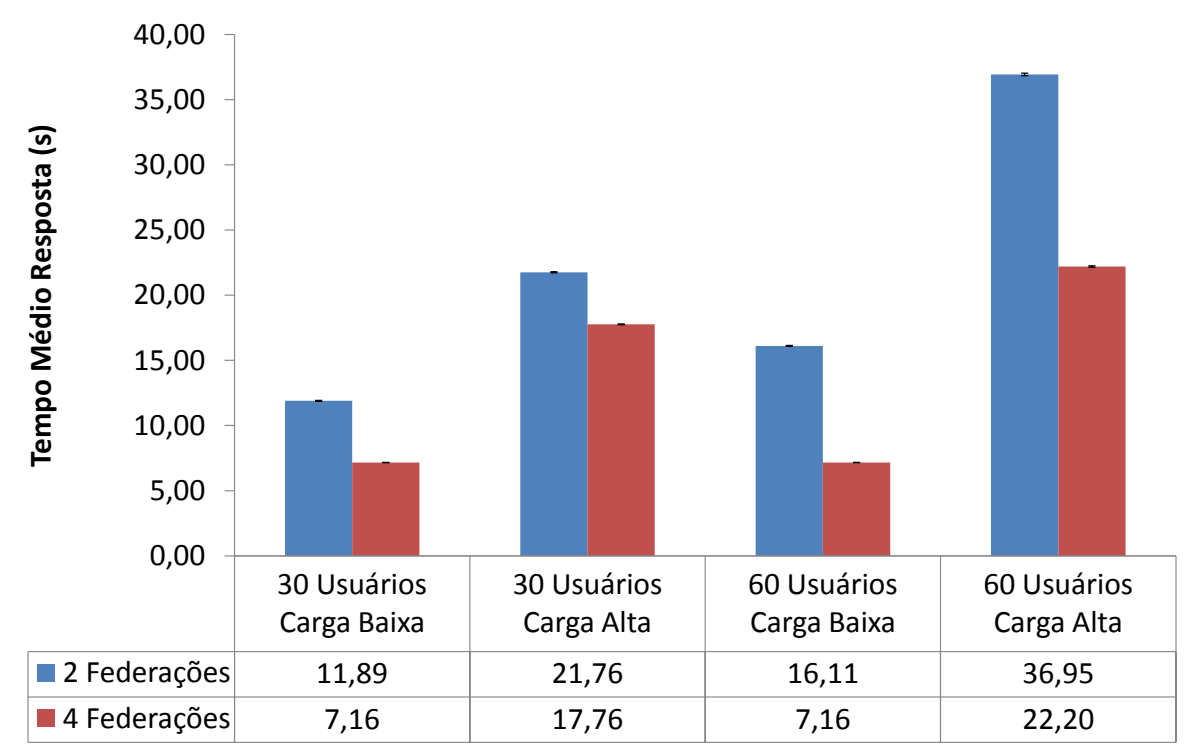

Figura 6.13: Tempo Médio de Resposta - Política MA.

Na Figura 6.13, com o aumento de $100 \%$ do número de federações, verifica-se uma redução no Tempo Médio de Resposta de 40\% para um ambiente com trinta usuários executando aplicações de carga Baixa. Essa redução é menor com aplicações de carga Alta, 18\%. No entanto, com sessenta usuários tem-se uma maior redução no Tempo Médio de Resposta, de 55\% para carga Baixa e de $40 \%$ para carga Alta.

Por outro lado, o aumento da carga Baixa para carga Alta proporciona o aumento do Tempo Médio de Resposta de $45 \%$ em um ambiente com trinta usuários e duas federações. Esse aumento é maior em um ambiente com sessenta usuários e duas federações, de $56 \%$, e em um ambiente com trinta e sessenta usuários e quatro federações, $60 \%$ e $68 \%$, respectivamente.

Além disso, com o aumento de $100 \%$ do número de usuários tem-se uma elevação no Tempo Médio de Resposta de $26 \%$ em um ambiente com duas federações e aplicações de carga Baixa. Com aplicações de carga Alta essa elevação é maior, de $41 \%$. Com a utilização de quatro federações essa elevação é inferior, de $0 \%$ para um ambiente com carga Baixa, o que mostra que não houve sobrecarga das federações, e de $20 \%$ para um ambiente com carga Alta.

- Quanto maior for a carga de uma aplicação, maior será o tempo gasto na sua execução e com isso, menor será o Throughput Médio. Esse Throughput Médio pode ser aumentado se existirem mais recursos disponíveis para a execução das aplicações, conforme é apresentado nos gráficos das Figuras 6.14, 6.15 e 6.16. 


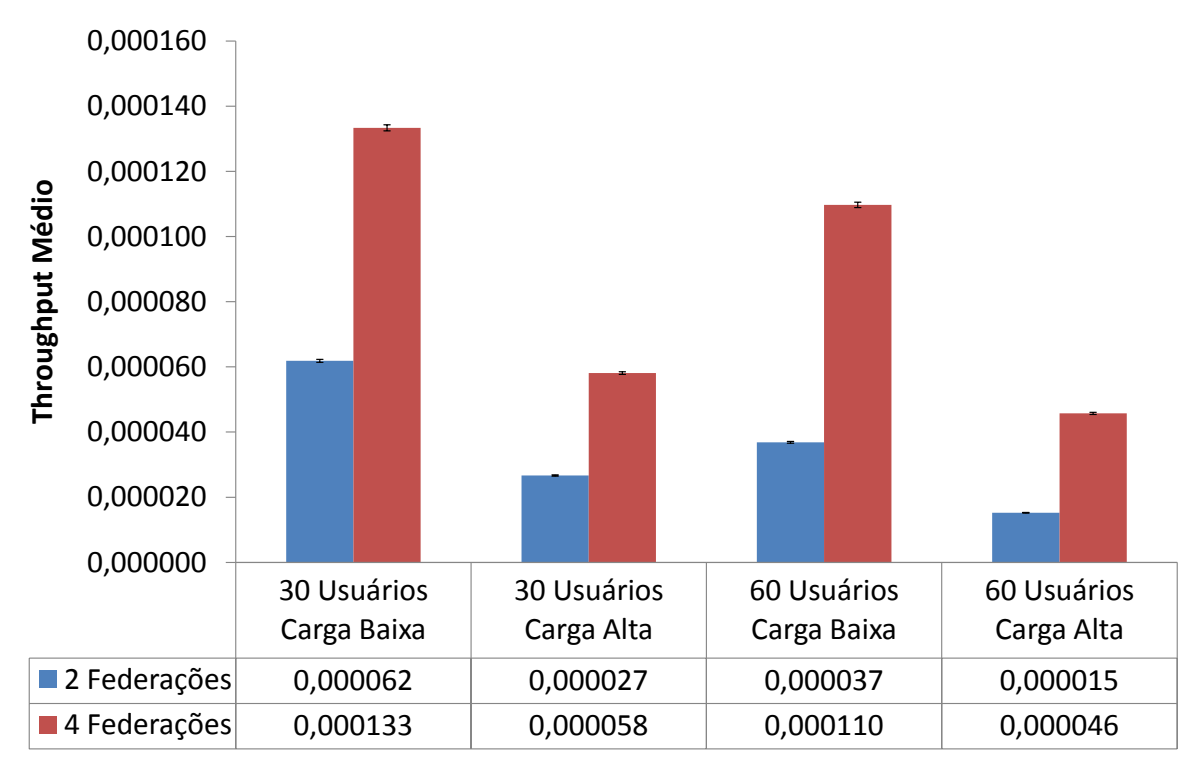

Figura 6.14: Throughput Médio - Política WQ.

Na Figura 6.14, com o aumento de $100 \%$ do número de federações, verifica-se um aumento no Throughput Médio de 53\% para um ambiente com trinta usuários executando aplicações de carga Baixa e Alta. No entanto, com sessenta usuários esse aumento no Throughput Médio é de 66\% para aplicações de carga Baixa e de $67 \%$ para aplicações de carga Alta.

Por outro lado, o aumento de $100 \%$ da carga Baixa para carga Alta proporciona a redução de $56 \%$ do Throughput Médio em um ambiente com trinta usuários e duas federações. Essa redução é pouco maior em um ambiente com sessenta usuários, de 58\%. Considerando quatro federações, essa redução mantêm-se a mesma para um ambiente com trinta e sessenta usuários, $56 \%$ e 58\%, respectivamente.

Além disso, com o aumento de $100 \%$ do número de usuários tem-se uma redução no Throughput Médio de $40 \%$ em um ambiente com duas federações e aplicações de carga Baixa. Com aplicações de carga Alta essa redução é pouco maior, de $44 \%$. Com a utilização de quatro federações essa redução é menor, de 17\% para um ambiente com carga Baixa e de $21 \%$ para um ambiente com carga Alta. 


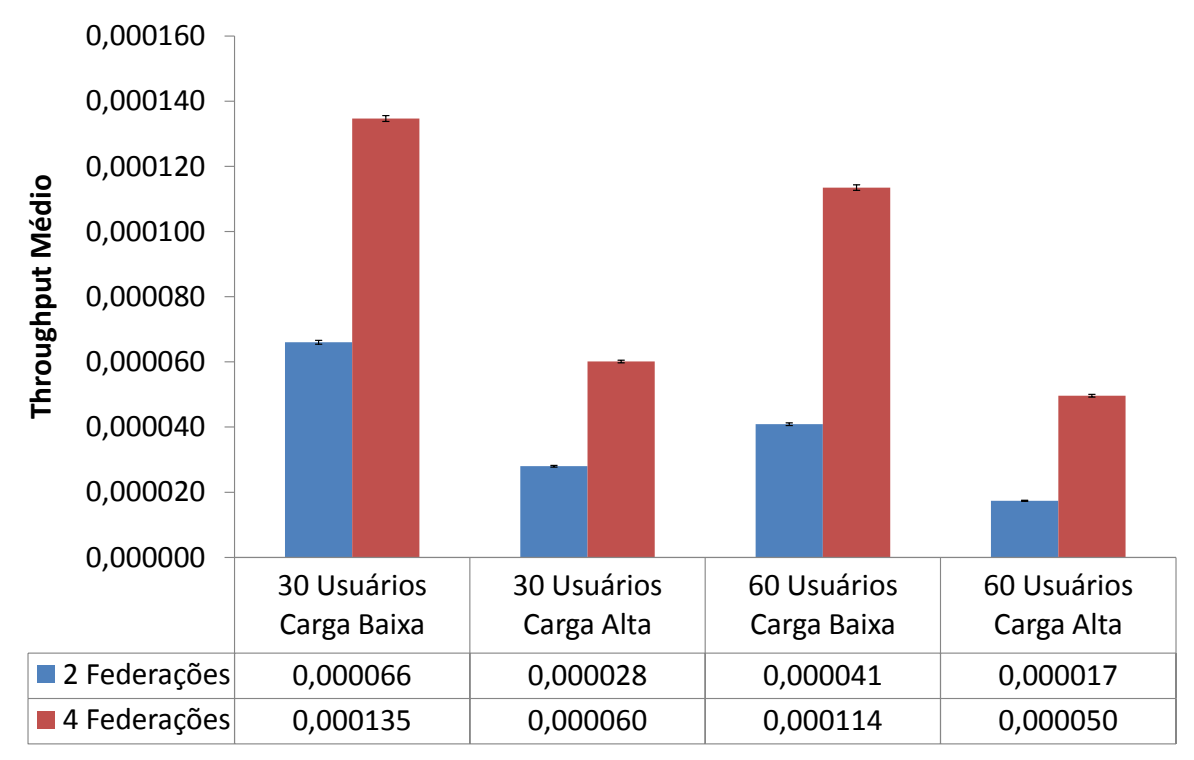

Figura 6.15: Throughput Médio - Política BC.

Na Figura 6.15, com o aumento de $100 \%$ do número de federações, verifica-se um aumento no Throughput Médio de 51\% para um ambiente com trinta usuários executando aplicações de carga Baixa e de 53\% para um ambiente com trinta usuários com aplicações de carga Alta. Com sessenta usuários esse aumento no Throughput Médio é de 64\% para aplicações de carga Baixa e de $66 \%$ para aplicações de carga Alta.

Por outro lado, o aumento de $100 \%$ da carga Baixa para carga Alta proporciona a redução de 58\% do Throughput Médio em um ambiente com trinta e sessenta usuários e duas federações. Considerando quatro federações, essa redução é pouco menor para um ambiente com trinta e sessenta usuários, $55 \%$ e $56 \%$, respectivamente.

Além disso, com o aumento de $100 \%$ do número de usuários tem-se uma redução no Throughput Médio de 38\% em um ambiente com duas federações e aplicações de carga Baixa. Com aplicações de carga Alta essa redução é similar, de 39\%. Com a utilização de quatro federações essa redução é menor, de $16 \%$ para um ambiente com carga Baixa e de $17 \%$ para um ambiente com carga Alta. 


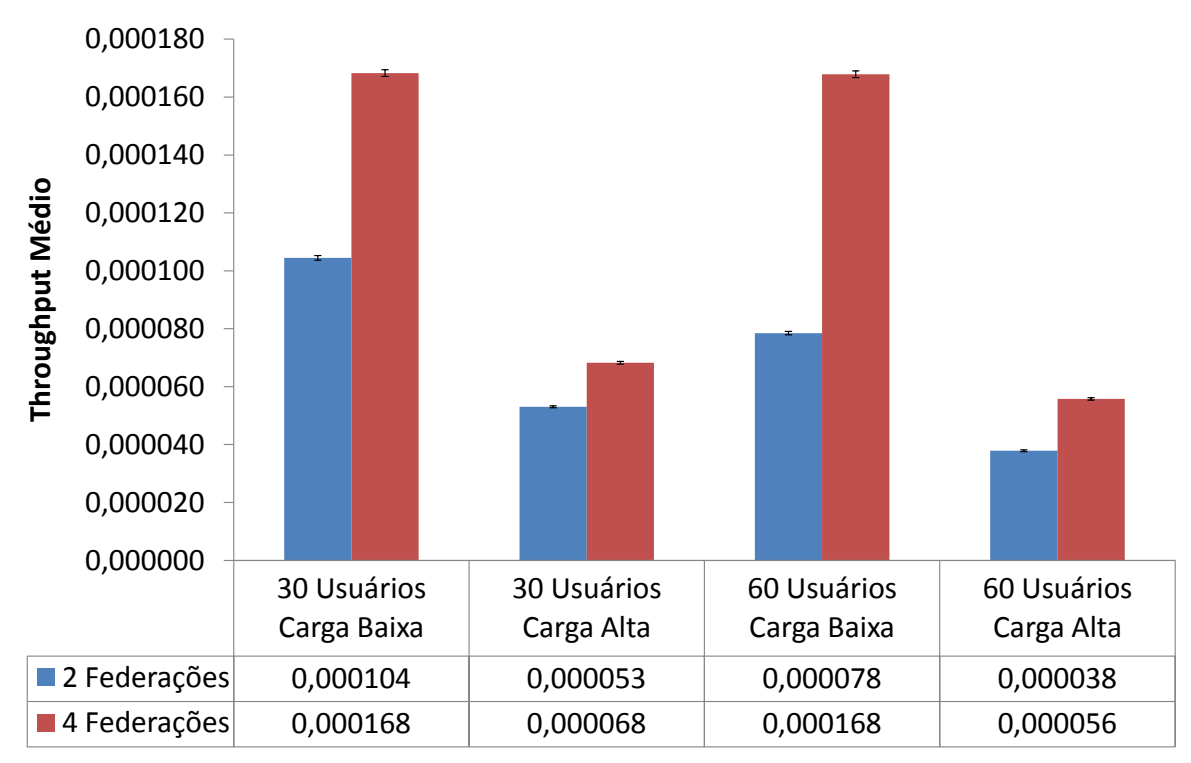

Figura 6.16: Throughput Médio - Política MA.

Na Figura 6.16, com o aumento de $100 \%$ do número de federações, verifica-se um aumento no Throughput Médio de 38\% para um ambiente com trinta usuários executando aplicações de carga Baixa e de $22 \%$ para um ambiente com trinta usuários com aplicações de carga Alta. Com sessenta usuários esse aumento no Throughput Médio é de 54\% para aplicações de carga Baixa e de 32\% para aplicações de carga Alta.

Por outro lado, o aumento de $100 \%$ da carga Baixa para carga Alta proporciona a redução de aproximadamente 50\% do Throughput Médio em um ambiente com trinta e sessenta usuários e duas federações. Considerando quatro federações, essa redução é maior para um ambiente com trinta e sessenta usuários, $59 \%$ e $67 \%$, respectivamente.

Além disso, com o aumento de $100 \%$ do número de usuários tem-se uma redução no Throughput Médio de 25\% em um ambiente com duas federações e aplicações de carga Baixa. Com aplicações de carga Alta essa redução é pouco maior, de $28 \%$. Com a utilização de quatro federações essa redução é menor, de $0 \%$ para um ambiente com carga Baixa, o que mostra que não houve sobrecarga das federações, e de $18 \%$ para um ambiente com carga Alta.

\subsection{Considerações Finais}

Com as simulações e análises realizadas verifica-se que o aumento no número de usuários e na carga aplicada ao sistema exige uma maior eficiência da política de escalonamento, pois esse aumento gera uma maior sobrecarga no sistema. Essa sobrecarga elevará o Tempo Médio de Resposta das aplicações se a política de escalonamento não for eficiente o bastante para realizar uma distribuição balanceada das aplicações aos recursos disponíveis, não permitindo que recursos permaneçam ociosos e nem sobrecarregados. 
Nos experimentos realizados a política Melhor Arranjo apresentou os melhores resultados em relação as variáveis de resposta Tempo Médio de Resposta e Throughput Médio, seguida pela política Baseada na Capacidade. A política WorkQueue mostrou-se menos eficiente, pois não leva em consideração informações sobre a carga que é aplicada ao sistema e sobre os recursos disponíveis nas federações. Com isso, os ambientes simulados com essa política tiveram os seus desempenhos prejudicados.

Além disso, observa-se que o aumento no número de federações reduz o Tempo Médio de Resposta e aumenta o Throughput Médio pois o número de recursos disponíveis para a execução das aplicações é maior. Por outro lado, quanto maior for o número de usuários e a carga das aplicações submetidas por eles, maior será o tempo gasto na execução e com isso, maior será o Tempo Médio de Resposta e menor será o Throughput Médio. 


\section{Conclusões}

\subsection{Considerações Iniciais}

Atualmente um telefone celular pode ser considerado um equipamento multimídia. Por meio dele é possível realizar acesso à Internet, executar aplicações de escritório (como editores de texto, planilhas eletrônicas, etc.), jogos, entre muitos outros. Quanto mais recursos esses aparelhos oferecem, maior é a sua popularidade. O projeto de mestrado apresentado por esta monografia acredita que uma situação similar ao que aconteceu com o aparelho celular acontecerá com os equipamentos receptores do Sistema de Televisão Digital Interativa. Uma vez que o consumidor adquira um equipamento dessa natureza, ele deverá ser capaz de utilizá-lo para uma grande gama de aplicações que o auxilie nas tarefas cotidianas.

No entanto, como acontece com todo produto comercializado no mercado, inúmeros fabricantes disponibilizarão inúmeros equipamentos com capacidades e características diferentes. Dessa forma, pessoas com um poder aquisitivo limitado tendem a comprar um equipamento com pouca capacidade adicional às funções básicas de recebimento e reprodução de áudio/vídeo e execução de aplicações interativas.

Com a inserção desses equipamentos em uma grade computacional promovida por meio do Grid Anywhere, um receptor digital operando no papel de consumidor de recursos poderá migrar partes da aplicação para serem executadas em outros receptores ou até mesmo em um computador convencional. Dessa forma, o receptor local fica exonerado de uma determinada carga de processamento e de memória. Esse tipo de abordagem permitirá que usuários que possuam equipamentos com configuração de hardware limitada executem aplicações que requisitem uma capacidade computacional maior que a ofertada pelo receptor. 
No entanto, a possibilidade de existir um grande número de participantes na grade computacional proposta pelo Grid Anywhere torna necessário que o mecanismo de escalonamento seja robusto e eficiente. Sendo assim, o objetivo deste projeto de mestrado foi verificar a sobrecarga que as aplicações interativas impõem sobre os diferentes modelos de receptores digitais e propor e avaliar algoritmos de escalonamento que possibilitem uma distribuição adequada de processos nos elementos da grade computacional proposta pelo Grid Anywhere. Foram avaliados algoritmos de escalonamento que consideram um cenário de sistema distribuído que utiliza os receptores digitais dos equipamentos domésticos de televisão nos papéis de provedores e consumidores de recursos computacionais. Para isso foram realizados estudos sobre os receptores digitais e aplicações interativas disponíveis. Com os dados obtidos, foram modelados e simulados ambientes de grades computacionais homogêneas e heterogêneas com as características do Grid Anywhere.

\subsection{Resultados Obtidos}

Este trabalho apresentou uma categorização e classificação de alguns equipamentos capazes de receber o sinal digital de televisão e de algumas aplicações interativas. Com os resultados obtidos foram modelados ambientes simulados para a execução dos experimentos, onde foram utilizados esses dados. Esses ambientes utilizaram as características definidas pelo middleware Grid Anywhere, onde qualquer tipo de equipamento dotado de recursos computacionais pode compor uma grade computacional. Nos experimentos realizados, verificou-se a sobrecarga imposta por diferentes tipos de aplicações interativas sobre classes distintas de receptores digitais. Além disso, este trabalho avaliou e propôs algoritmos de escalonamento que possibilitam a distribuição das aplicações dos usuários para serem executadas nas federações que são compostas por receptores digitais.

\subsection{Conclusão Final}

Para a realização dos experimentos foram caracterizados e categorizados vinte e um equipamentos disponíveis comercialmente. Utilizando-se desses equipamentos pode-se prever a potência computacional disponível. Também foram caracterizadas as aplicações interativas, obtendo-se o nível de utilização que essas aplicações fazem dos processadores.

Nos primeiros experimentos realizados verificou-se a sobrecarga imposta por diferentes tipos de aplicações sobre as classes de receptores digitais definidas neste trabalho. A grade computacional composta somente por equipamentos Classe 3 teve o seu desempenho prejudicado quando comparada com as outras compostas por Classes 1 e 2 na execução das aplicações, visto que são equipamentos com recursos computacionais limitados. Assim, analisando o perfil da sociedade brasileira onde são predominantes as Classes C, D e E, percebe-se que o poder aquisitivo nessas classes é muito menor que os da Classe A e B. Conseqüentemente, essas pessoas tendem a com- 
prar equipamentos onde os recursos computacionais são limitados. Isso pode prejudicar a inclusão dessas pessoas no sistema de TV Digital que está em implantação no Brasil.

Assim, torna-se interessante a composição de uma grade computacional heterogênea composta por equipamentos das Classes 1, 2 e 3, onde um usuário com receptor digital com recursos limitados pode migrar as suas aplicações para serem executadas em equipamentos mais potentes.

Na segunda avaliação realizada foram comparadas três políticas de escalonamento: WorkQueue (WQ), muito conhecida em grades computacionais, Baseada na Capacidade (BC) e Melhor Arranjo (MA), propostas neste trabalho. Os experimentos apresentados no Capítulo anterior mostram como as aplicações interativas dos usuários podem ser executadas nos equipamentos disponíveis no momento como receptores digitais.

Nos experimentos realizados percebeu-se que a política MA apresentou menores Tempos Médios de Resposta quando comparada com as políticas BC e WQ. Isso ocorre, pois a política MA realiza uma análise dos recursos e das aplicações disponíveis antes de direcioná-las para execução. Essa análise permite um melhor balanceamento de carga no sistema, além de redução no Tempo Médio de Resposta e aumento do Throughput Médio. Já a política BC realiza apenas uma análise dos recursos disponíveis para determinar o quanto uma federação é, na média, mais potente que as demais. Essa média determina o número de aplicações que a federação mais potente receberá a mais para executar. No entanto, isso pode gerar sobrecarga na federação mais potente e ociosidade nas demais, pois não são levadas em consideração informações sobre as aplicações. Por fim, a política WQ, não usa nenhuma informação do sistema durante o escalonamento e a distribuição das aplicações é feita de forma aleatória, bastando que o recurso esteja disponível e que exista aplicação para ser escalonada. Com isso, o desempenho do sistema pode ser prejudicado, visto que uma aplicação que exige muito processamento pode ser submetida para execução em um recurso com baixa potência computacional.

\subsection{Trabalhos Futuros}

Algumas sugestões são apresentadas para trabalhos futuros. São elas:

- Implementação de políticas de escalonamento que analisem a disponibilidade dos equipamentos receptores que compõem a grade computacional: quando um ambiente de Televisão Digital Interativa é considerado no contexto de uma grade computacional, um número grande de participantes pode ser encontrado no sistema. Um comportamento dinâmico deve ser considerado, pois telespectadores podem ligar e desligar seus receptores a qualquer momento. Isso compromete a utilização de receptores para executar objetos migrados por outros usuários. Sendo assim, é necessário algoritmos de escalonamento inteligentes e capazes de procurar equipamentos em função do perfil dos usuários. Além de ser necessário que o middleware tenha habilidades para lidar com situações onde o equipamento remoto torna-se indisponível durante o processamento de uma requisição. 
- Criação de uma grade computacional utilizando máquinas virtuais: existem versões de receptores digitais virtualizados disponíveis para download, como é o caso do Set-top Box Virtual Ginga-NCL, utilizado neste trabalho. Esses receptores podem ser utilizados na composição de uma grade computacional juntamente com um nó servidor que atuará no papel da emissora de televisão. Assim esse nó servidor pode enviar aplicações para serem executadas nos receptores virtualizados o que permite que seja realizada uma avaliação de desempenho mais detalhada do ambiente com as características do Grid Anywhere utilizando diferentes políticas de escalonamento.

- Expansão para Cloud Computing (Computação nas Nuvens): nos dias atuais, computação nas nuvens é o assunto do momento dentro da indústria de TI. Ele é baseado em muitos anos de pesquisa em diversas áreas da computação como sistemas distribuídos, virtualização, tolerância a falhas, balanceamento de carga, interoperabilidade, aplicações Web 2.0, computação utilitária (Utility Computing) e computação autônoma (Autonomic Computing) (Rimal et al., 2009). Computação nas Nuvens ou Cloud é uma analogia a um conjunto de componentes que executam serviços sob demanda dos usuários. O consumidor geralmente não tem idéia de onde estes serviços são executados, por isso, tornou-se comum dizer que os serviços estão nas "Nuvens" (Armbrust et al., 2009). Considerando o ambiente apresentado neste trabalho é possível uma expansão para cloud. Nele usuários e emissora podem se comunicar através de um canal de comunicação com acesso a Internet. No entanto, se o número de requisições de serviço feitas pelos usuários da emissora for muito grande, a emissora pode ser o gargalo do sistema, pois ela será sobrecarregada. Com isso o desempenho do sistema será muito prejudicado, visto que a emissora recebe as solicitações de serviço e, utilizando as políticas de escalonamento, distribui esses serviços para serem executadas nos recursos que compõem as federações. Uma solução para este problema de sobrecarga é a inserção de uma cloud. Assim pode-se inserir um módulo na emissora onde todas as requisições seriam tratadas pela cloud. Outra possibilidade é a utilização da cloud para a execução das aplicações dos usuários. Assim, os usuários não necessitariam de receptores digitais com grande potência computacional. Basta apenas um equipamento com a funcionalidade de receber o conteúdo digital (áudio, vídeo e aplicações interativas) e com acesso a Internet. Com isso, sempre que um usuário desejar executar alguma aplicação interativa, ele pode enviá-la para ser executada na cloud, já que o seu receptor não possui potência computacional para realizar tal processamento. É claro que nesse contexto deve-se levar em consideração a velocidade da rede. 
ABNT, N. Norma brasileira 15604. Televisão digital terrestre-Receptores, 2007.

Ali, S.; Kim, J.; Siegel, H.; Maciejewski, A.; Yu, Y.; Gundala, S.; Gertphol, S.; PRASANNA, V. Greedy heuristics for resource allocation in dynamic distributed real-time heterogeneous computing systems. In: 2002 International Conference on Parallel and Distributed Processing Techniques and Applications (PDPTA 2002, Citeseer, 2002, p. 519-530.

Alice Alice a large ion collider experiment. Disponível em: http://public.web.cern.ch/PUBLIC/en/LHC/ALICE-en.html., 2006.

AndrieuX, A.; Berry, D.; Garibaldi, J.; Jarvis, S.; Maclaren, J.; Ouelhadu, D.; SNELLING, D. Open issues in grid scheduling. UK e-Science Report UKeS-2004-03, April, 2004.

Armbrust, M.; Fox, A.; Griffith, R.; Joseph, A.; Katz, R.; Konwinski, A.; Lee, G.; Patterson, D.; Rabin, A.; Stoica, I.; ET Al. Above the clouds: A berkeley view of cloud computing. EECS Department, University of California, Berkeley, Tech. Rep. UCB/EECS-2009-28, 2009.

ATLAS Atlas a toroidal lhe apparatus. Disponível em: http://public.web.cern.ch/PUBLIC/en/LHC/ATLAS-en.html, 2006.

ATSC Advanced television systems committee. Disponível em: http://www.atsc.org/cms/, 2011.

Bagrodia, R.; Meyer, R.; Takai, M.; Chen, Y.; Zeng, X.; Martin, J.; Song, H. Parsec: A parallel simulation environment for complex systems. Computer, v. 31, n. 10, p. 77-85, 1998.

BAKER, M.; BUYYA, R.; LAFOREnZA, D. Grids and grid technologies for wide-area distributed computing. Software: Practice and Experience, v. 32, n. 15, p. 1437-1466, 2002.

Barbosa, S.; SoAres, L. Tv digital interativa no brasil se faz com ginga: Fundamentos, padrões, autoria declarativa e usabilidade. atualizações em informática, p. 105-174, 2008. 
Batista, C.; Araujo, T.; Omaia, D.; Anjos, T.; Castro, G.; Brasileiro, F.; De Souza FILHO, G. Tvgrid: A grid architecture to use the idle resources on a digital tv network. IEEE Computer Society, 2007.

BUYYA, R.; MURSheD, M. Gridsim: A toolkit for the modeling and simulation of distributed resource management and scheduling for grid computing. Concurrency and Computation: Practice and Experience. Wiley Online Library, v. 14, n. 13-15, p. 1175-1220, 2002.

Casanova, H. Simgrid: A toolkit for the simulation of application scheduling. In: Cluster Computing and the Grid, 2001. Proceedings. First IEEE/ACM International Symposium on, IEEE, 2001, p. 430-437.

Casanova, H.; Zagorodnov, D.; Berman, F.; Legrand, A. Heuristics for scheduling parameter sweep applications in grid environments. In: $h c w$, Published by the IEEE Computer Society, 2000, p. 349.

CAStro, F. Participação brasileira no lhc é assegurada. Disponível em: http://www.agencia.fapesp.br/materia/10331/especiais/participacao-brasileira-no-lhc-eassegurada.htm, 2006.

CERN Cern photolab. Disponível em: http://cdsweb.cern.ch/record/1103476\#01, 2008.

ClubenCL Repositório de aplicações interativas. Disponível em: clube.ncl.org.br, 2011.

CMS Cms compact muon solenoid. Disponível em: http://public.web.cern.ch/PUBLIC/en/LHC/CMS-en.html, 2006.

CPQD Modelo de referência: Sistema brasileiro de televisão digital terrestre. funttel projeto sistema brasileiro de televisão digital - os 40539. Disponível em: http://www.fndc.org.br/internas.php?p=listdocumentos\&categ_key=52, 2006.

CPQD Página oficial do cpqd. Disponível em: http://www.cpqd.com.br/, 2011.

CPUBEnchmarks Página cpu benchmarks. Disponível em: http://www.cpubenchmark.net/, 2011.

DAntas, M. Computação distribuída de alto desempenho: redes, clusters e grids computacionais. Axcel Books, 2005.

DONG, F.; AKL, S. Scheduling algorithms for grid computing: State of the art and open problems. School of Computing, Queen's University, Kingston, Ontario, 2006.

Donno, F. Storage management and access in wlhc computing grid. Tese de Doutoramento, University of Pisa, 2006.

DTV Página oficial da tv digital brasileira. Disponível em: www.dtv.org.br, 2011. 
Dumitrescu, C.; Foster, I. Gangsim: a simulator for grid scheduling studies. In: Cluster Computing and the Grid, 2005. CCGrid 2005. IEEE International Symposium on, IEEE, 2005, p. 1151-1158.

DVB Dvb - the global standard for digital television. Disponível em: http://www.dvb.org/, 2011.

ESTADAO Unicamp usa rede de playstation 3 para estudar remédios. Disponível em: http://www.estadao.com.br/noticias/tecnologia,unicamp-usa-rede-de-playstation-3para-estudar-remedios,65721,0.htm, 2007.

FAPESP Video game aplicado em pesquisa. Disponível em: http://www.agencia.fapesp.br/materia/7893/especiais/videogame-aplicado-em-pesquisa.htm, 2007.

FERnANDES, J.; LEMos, G.; SILVEIRA, G. Introdução à televisão digital interativa: arquitetura, protocolos, padrões e práticas. In: Congresso da Sociedade Brasileira de Computação, 2004.

FOLDING Página oficial do projeto folding@home. Disponível em: http://folding.stanford.edu/, 2006.

Foster, I.; KeSSELMAN, C. The grid: blueprint for a new computing infrastructure. Morgan Kaufmann, 2004.

Foster, I.; Kesselman, C.; Nick, J.; Tuecke, S. The physiology of the grid: An open grid services architecture for distributed systems integration. In: Open Grid Service Infrastructure WG, Global Grid Forum, Edinburgh, 2002, p. 1-5.

Foster, I.; Kesselman, C.; Tuecke, S. The anatomy of the grid: Enabling scalable virtual organizations. International Journal of High Performance Computing Applications. SAGE Publications, v. 15, n. 3, p. 200, 2001.

G1 Fogão e aparelho de tv são os bens presentes em mais casas brasileiras. Disponível em: http://g1.globo.com/Noticias/Brasil/0,,MUL1308909-5598,00FOGAO+E+APARELHO+DE+TV+SAO+OS+BENS+PRESENTES+EM+MAIS + CASAS+BRASILEIRAS.html, 2008.

GingA Middleware aberto do sistema brasileiro de tv digital (sbtvd). Disponível em: www.ginga.org.br, 2011.

GingANCL Pígina do ginga ncl. Disponível em: http://www.gingancl.org.br/, 2011.

Globus Página oficial do globus. Disponível em: http://www.globus.org/, 2011.

GPU Gpu acceleration of molecular modeling applications. Disponível em: http://www.ks.uiuc.edu/Research/gpu/, 2011. 
GPUGRID.NET Página oficial do projeto gpugrid.net. Disponível em: http://www.gpugrid.net/, 2011.

GRIDSIM A grid simulation toolkit for resource modelling and application scheduling for parallel and distributed computing. Disponível em: www.cloudbus.org/gridsim/, 2011.

Gschwind, M.; Hofstee, H.; Flachs, B.; Hopkin, M.; Watanabe, Y.; Yamazaki, T. Synergistic processing in cell's multicore architecture. Micro, IEEE, v. 26, n. 2, p. 10-24, 2006.

Halfhill, T. R. Parallel processing with cuda - nvidia's high-performance computing platform uses massive multithreading. Disponível em: http://www.nvidia.com/docs/IO/55972/220401_Reprint.pdf, 2008.

Harvey, M.; Giupponi, G.; Villa-FreiXa, J.; De Fabritis, G. Ps3grid net: Building a distributed supercomputer using the playstation 3. Distributed and Grid Computing - Science Made Transparent for Everyone. Principles, Applications and Supporting Communities; Weber, MHW, Ed.; Rechenkraft. net eV: Marburg, Germany, 2007.

Hofmann, R.; Klar, R.; Mohr, B.; Quick, A.; Siegle, M. Distributed performance monitoring: Methods, tools, and applications. Parallel and Distributed Systems, IEEE Transactions on, v. 5, n. 6, p. 585-598, 1994.

JAIN, R. The art of computer systems performance analysis: techniques for experimental design, measurement, simulation, and modeling. New York, NY, USA, Wiley, 1991.

KNight, P. T. Tv digital interativa: O canal de retorno que falta. 2007.

KoBAYASHI, H. Modeling and analysis: an introduction to system performance evaluation methodology. Addison-Wesley, 1978.

Kosar, T.; Balman, M. A new paradigm: Data-aware scheduling in grid computing. Future Generation Computer Systems, v. 25, n. 4, p. 406-413, 2009.

Kreutzer, W.; Hopkins, J.; VAn Mierlo, M. Simjava - a framework for modeling queueing networks in java. In: Proceedings of the 29th conference on Winter simulation, IEEE Computer Society, 1997, p. 483-488.

LAVID Lavid - laboratório de aplicações de vídeo digital. Disponível em: http://www.lavid.ufpb.br/, 2011.

LeAl, K.; Huedo, E.; Llorente, I. A decentralized model for scheduling independent tasks in federated grids. Future Generation Computer Systems, v. 25, n. 8, p. 840-852, 2009.

Legrand, A.; Marchal, L.; CASAnOVA, H. Scheduling distributed applications: the simgrid simulation framework. In: Cluster Computing and the Grid, 2003. Proceedings. CCGrid 2003. 3rd IEEE/ACM International Symposium on, IEEE, 2003, p. 138-145. 
LHC Lhc computing grid - technical design report. Disponível em: http://cern.ch/LCG/TDR/LCG_TDR_v1_04.pdf, 2005.

LHC Lhc milestones 2008. Disponível em: http://lhc-milestones.web.cern.ch/LHCMilestones/year2008-en.html, 2008.

LHC Túnel do lhc 2009 - físicos de sp acompanham lançamento do lhc. Disponível em: http://www.unesp.br/int_noticia_imgesq.php?artigo=3636, 2009.

LHCB Large hadron collider beauty. Disponível em: http://public.web.cern.ch/PUBLIC/en/LHC/LHCb-en.html, 2006.

LUA Liguagem de programação lua. Disponível em: http://www.lua.org/, 2011.

MacDougall, M. Simulating computer systems: techniques and tools. 1987.

Maeda, S.; Asano, S.; Shimada, T.; Awazu, K.; Tago, H. A real-time software platform for the cell processor. Micro, IEEE, v. 25, n. 5, p. 20-29, 2005.

Maheswaran, M.; Ali, S.; Siegal, H.; Hensgen, D.; Freund, R. Dynamic matching and scheduling of a class of independent tasks onto heterogeneous computing systems. In: Heterogeneous Computing Workshop, 1999.(HCW'99) Proceedings. Eighth, IEEE, 1999, p. 3044.

MENG, X. Distributed simulations: Issues and implementations in a cluster of workstations environment. COMPUT SYST SCI ENG, v. 14, n. 1, p. 27-37, 1999.

MERCURY, C. S. I. Algorithm performance on the cell broadband engine processor. Disponível em: http://www.mc.com/uploadedFiles/Cell-Perf-Simple.pdf, 2006.

Minicom Portal das comunicações. Disponível em: www.mc.gov.br, 2011.

Montez, C.; Becker, V. Tv digital interativa: conceitos, desafios e perspectivas para o brasil. Universidade Federal de Santa Catarina, 2005.

Moore, S. Winner: Multimedia monster. IEEE Spectrum, v. 43, n. 1, p. 20-23, 2006.

MUNIR, E.; LI, J.; SHI, S. Qos sufferage heuristic for independent task scheduling in grid. Information Technology Journal, v. 6, n. 8, p. 1166-1170, 2007.

Neves, R. B. Explorando o canal de retorno em sistema de televisão digital interativa: uma abordagem centrada no suporte à comunicação entre as aplicações e provedores de serviços. Dissertação de Mestrado, Programa de Pós-Graduação em Informática, Pontifícia Universidade Católica de Minas Gerais., Belo Horizonte - Minas Gerais, 2010. 
O'DRISCOLL, G. The essential guide to digital set-top boxes and interactive tv. Prentice Hall PTR Upper Saddle River, NJ, USA, 1999.

Peixoto, M. L. M. Proposta e desenvolvimento de uma arquitetura para obtenção de qos em uma grade de serviços. 2009.

PICCOLO, L. Arquitetura do set-top box para tv digital interativa. Instituto de ComputaçãoUnicamp, 2005.

Planalto Decreto presidencial 4901 de 26 de novembro de $2003 . \quad$ Disponível em: sbtvd.cpqd.com.br/downloads/decreto_4901_2003.pdf, 2003.

Rimal, B.; ChOI, E.; LumB, I. A taxonomy and survey of cloud computing systems. In: 2009 Fifth International Joint Conference on INC, IMS and IDC, IEEE, 2009, p. 44-51.

Rodamilans, C. Análise de desempenho de algoritmos de escalonamento de tarefas em grids computacionais usando simuladores. 2009.

SAntAnA, M. J. Advanced filestore architeture for a multiple-lan distributed computing system. 1990a.

SantanA, R. H. C. Performance evaluation of lan-based file server. $1990 \mathrm{~b}$.

Santana, R. H. C.; Santana, M. J.; Frances, C. R. L.; Orlandi, R. C. G. S. Tool and methodologies for performance evaluation of distributed computing system - a comparison study. 1997.

Santos JR, J.; Ávila, P.; Baldini, R.; Ishitani, L.; NAscimento, R.; SAntos, M. Trends on building interactive applications in the brazilian digital televison system. In: Proceedings of the 7th IEEE conference on Consumer communications and networking conference, IEEE Press, 2010, p. 973-977.

Santos Neto, E. Escalonamento de aplicações que processam grandes quantidades de dados em grids computacionais. 2004.

Schwiegelshohn, U.; Badia, R.; Bubak, M.; Danelutto, M.; Dustdar, S.; GagliArdi, F.; Geiger, A.; Hluchy, L.; Kranzlmuller, D.; Laure, E.; Et Al. Perspectives on grid computing. Future Generation Computer Systems, v. 26, n. 8, p. 1104-1115, 2010.

SETI@HOME Página oficial do projeto seti@home. Disponível em: http://setiathome.berkeley.edu/, 2011.

Silberschatz, A.; Galvin, P.; Gagne, G. Sistemas operacionais-conceitos e aplicações. Rio de Janeiro: Campus, 2001. 
Silva, D.; Cirne, W.; Brasileiro, F. Trading cycles for information: Using replication to schedule bag-of-tasks applications on computational grids. Euro-Par 2003 Parallel Processing, p. 169-180, 2004.

SOARES, L. Modelagem e simulação discreta de sistemas. Campus, 1992.

Song, H.; LiU, X.; Jakobsen, D.; Bhagwan, R.; Zhang, X.; Taura, K.; Chien, A. The microgrid: a scientific tool for modeling computational grids. 2000.

STICKERCENTER Página do stickercenter. Disponível em: https://www.stickercenter.com.br/StickerWeb/pt_BR/index.html, 2011.

Sulistio, A.; Yeo, C.; BuYyA, R. A taxonomy of computer-based simulations and its mapping to parallel and distributed systems simulation tools. Software: Practice and Experience, v. 34, n. 7, p. 653-673, 2004.

TAKEFUSA, A. Bricks: A performance evaluation system for scheduling algorithms on the grids. In: JSPS workshop on applied information technology for science, 2001.

TAO, F.; HU, Y.; ZhaO, D.; ZhOU, Z. An approach to manufacturing grid resource service scheduling based on trust-qos. International Journal of Computer Integrated Manufacturing, v. 22, n. 2, p. 100-111, 2009.

Teixeira, F.; Santana, M.; Santana, R.; Bruschi, S.; J.C., E. Sam Dog: A Java Sandbox Using a Cascading Access Control List Approach. Enabling Technologies: Infrastructure for Collaborative Enterprises (WETICE), 2011 20th IEEE International Workshops on. Paris, France, p. 134-136, 2011.

Teixeira, F.; Santana, M.; Santana, R.; J.C., E. Grid Anywhere: An Architecture for Grid Computing Able to Explore the Computational Resources of the Set-Top Boxes. Networks for Grid Applications. Springer, p. 79-88, 2010.

TEIXEIRA, F. C. Grid@tv: Um middleware para grades computacionais extensível aos receptores de sinais digitais de televisão. Tese de Doutoramento, Monografia de qualificação de doutorado apresentada ao Instituto de Ciências Matemáticas e de Computação - ICMC, USP, São Carlos, São Paulo, 2009.

TELEMIDIA Telemidia - laboratório de sistemas multimídia. Disponível em: http://www.telemidia.puc-rio.br/pt/index.html, 2011.

Tonieto, M. Sistema brasileiro de tv digital - sbtvd uma análise política e tecnológica na inclusão social. 2006. 
Wieczorek, M.; Hoheisel, A.; Prodan, R. Towards a general model of the multi-criteria workflow scheduling on the grid. Future Generation Computer Systems, v. 25, n. 3, p. 237-256, 2009.

WLCG Wlcg - what is the worldwide lhc computing grid? Disponível em: http://lcg.web.cern.ch/LCG/public/overview.htm, 2006.

WSRF The ws-resource framework. Disponível em: http://www.globus.org/wsrf/, 2011.

ZHU, Y. A survey on grid scheduling systems. APWeb/WAIM, p. 419-427, 2007.

Zuffo, M. TV Digital Aberta no Brasil-Políticas Estruturais para um Modelo Nacional. Escola Politécnica, USP, São Paulo, 2006. 